*ak RMIS View/Frint Document Cover Sheet tow

This document was retrieved from the Documentation and Records Manaqement (DRM) ISEARCH System. It is intended for Information only and may not be the most recent or updated version. Contact a Document Service Center (see Hanford Info for locations) if you need additional retrieval information.

Accession \#: D196093585

Document \#: SD-CP-FDC-003

Title/Desc:

PFP SOLUTION STABILIZATION

Pages: 104 


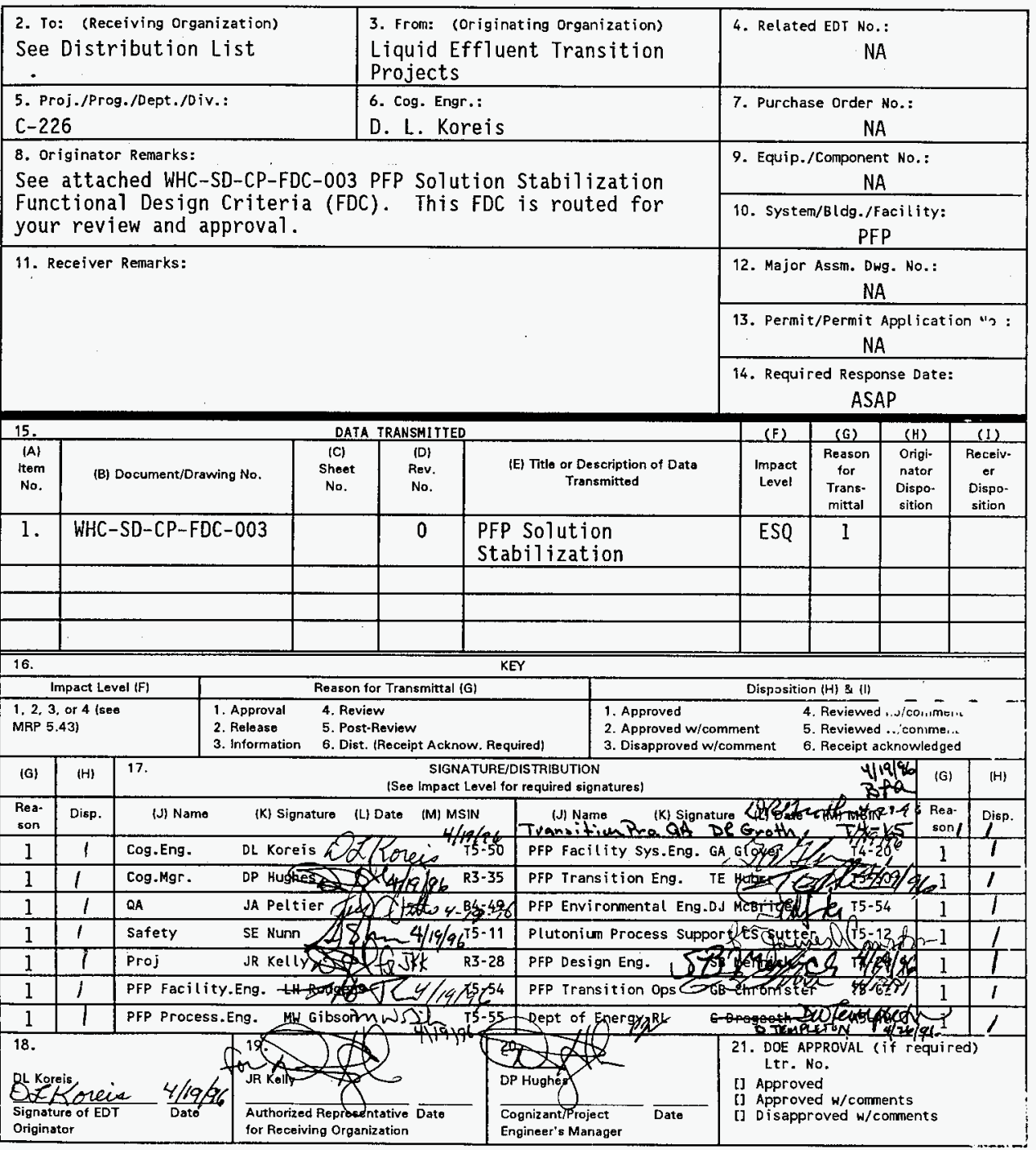

BD-7400-172-2 (07/91) GEF097 


\title{
PFP Solution Stabilization
}

\author{
Barbara L. Aftanas
}

Westinghouse Hanford Company, Richland, WA 99352

U.S. Department of Energy Contract DE-AC06-87RL10930

EDT/ECN: $615713 \quad$ UC: UC-721

Org Code: 75250

B\&R Code: EW7003000

$\begin{array}{ll}\text { Charge Code: } & \mathrm{K} 6137 \\ \text { Total Pages: } & 101\end{array}$

Key Words: Plutonium, PFP, Solution, Stabilization, FDC, Calciner

Abstract: This Functional Design Criteria (FDC) addresses remediation of the plutonium-bearing solutions currently in inventory at the Plutonium Finishing Plant (PFP).

The recommendation from the Environmental Impact Statement (EIS) is that the solutions be treated thermally and stabilized as a solid for long term storage.

For solutions which are not discardable, the baseline plan is to utilize a denitration process to stabilize the solutions prior to packaging for storage.

TRADEMARK DISCLAIMER. Reference herein to any specific commercial product, process, or service by trade name, trademark, manufacturer, or otherwise, does not necessarily constitute or inply its endorsement, recommendation, or favoring by the United States Government or any agency thereof or its contractors or subcontractors.

Printed in the United States of America. To obtain copies of this document, contact: WHC/BCS Document Control Services, P.0. Box 1970; Mailstop H6-08, Richland WA 99352, Phone (509) 372-2420; Fax (509) 376-4989.
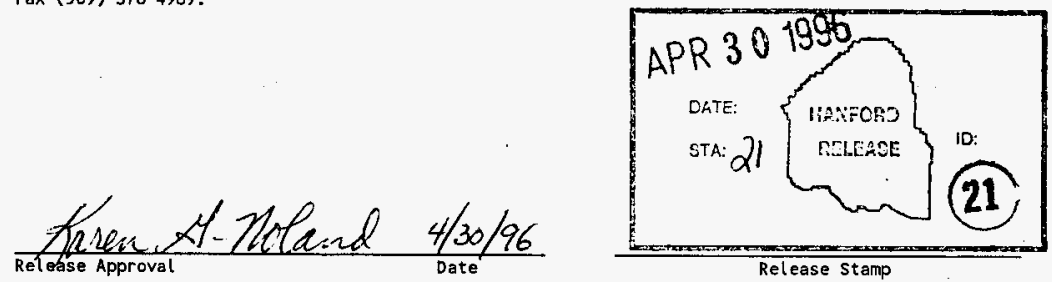

Release Stamp

\section{Approved for Public Release}


FUNCTIONAL DESIGN CRITERIA

PFP SOLUTION STABILIZATION, PROJECT C-226

Issued by:

WESTINGHOUSE HANFORD COMPANY

April 19, 1996

for the

U.S. DEPARTMENT OF ENERGY

RICHLAND OPERATIONS OFFICE

RICHLAND, WASHINGTON

PREPARED BY:

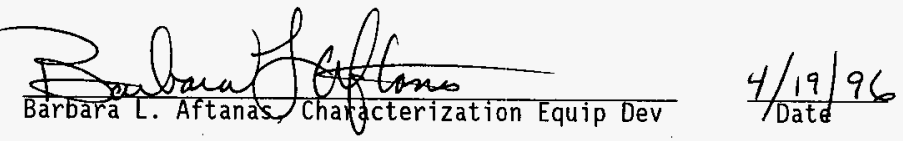

WHC APPROVALS:
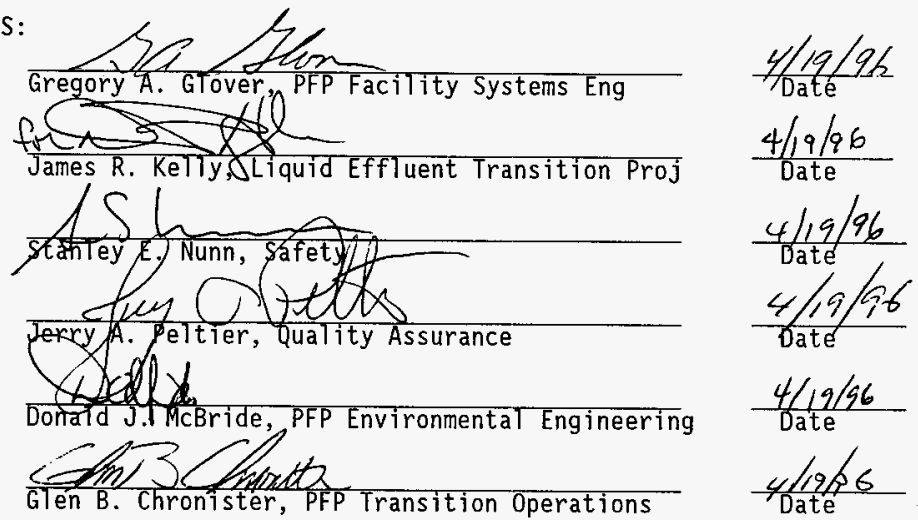

DEPARTMENT OF ENERGY APPROVAL:
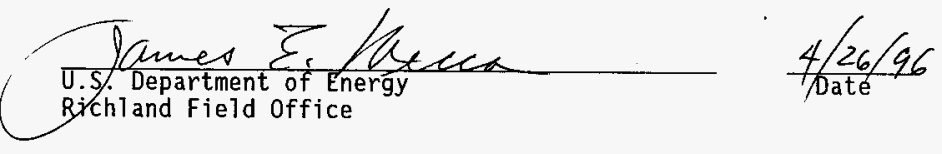
PFP SOLUTION STABILIZATION FUNCTIONAL DESIGN CRITERIA

\author{
TABLE OF CONTENTS
}

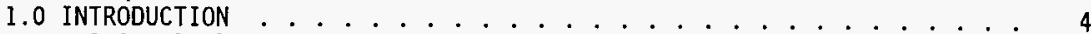

1.1 Background . . . . . . . . . . . 4

1.2 Scope ........................ 4

1.3 Justification . . . . . . . . . . . . . 5

1.4 Site Location . . . . . . . . . . . . . . . . . 5

1.5 Project Integration . . . . . . . . . . . 6

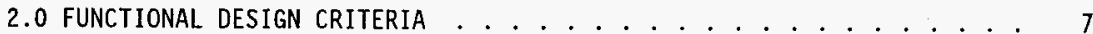

2.I General Guidelines . . . . . . . . . . . . . . . . 7

2.2 Component Design Life . . . . . . . . . . . . . . . 7

2.3 Materials . . . . . . . . . . . . . . . 7

2.4 Required Availability . . . . . . . . . 7

2.5 0perability and Maintainability........... 8

3.0 PROCESS CRITERIA . . . . . . . . . . . . . . . 9

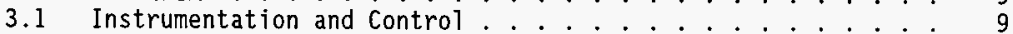

3.2 Piping and Vessels ................ . . . 9

3.3 General Process . . . . . . . . . . . . . . . . . . g g

3.4 General Mechanical Processes ............. g

4.0 FACILITY CRITERIA . . . . . . . . . . . . . . . 11

4.1 Architectural and Civil/structural ............. 11

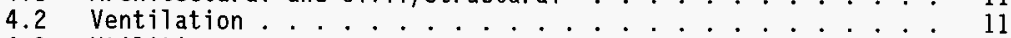

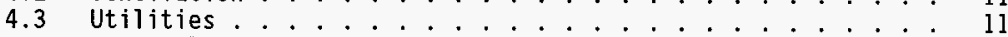

4.3.1 Electrical . . . . . . . . . . . . 12

4.3.2 Lighting . . . . . . . . . . . . . . 12

4.4 Communications Systems ................ . . . 12

4.5 Automatic Data Processing . . . . . . . . . . 12

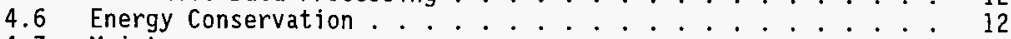

4.7 Maintenance .................... 12

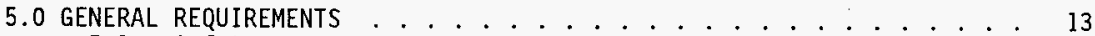

5.1 Safety .................... 13

5.1 .1 Criticality . . . . . . . . . . . . . 13

5.1 .2 Safety Analysis . . . . . . . . . . . . . . 13

5.1 .3 Contamination Control . . . . . . . . . 13

5.1 .4 Shielding. . . . . . . . . . . . . . . 14

5.1 .5 Industrial Safety . . . . . . . . . . . . 14

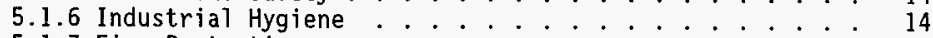

5.1 .7 Fire Protection . . . . . . . . . . . . 14

5.1 .8 Traffic Safety . . . . . . . . . . 14 
5.2 Environmental Protection and Compliance . . . . . . . . . 14

5.3 Safeguards and Security................... 15

5.4 Natural Forces . . . . . . . . . . . . . . . . . 16

5.5 Design Format . . . . . . . . . . . . . . . . . . . . . . . . 16

5.6 Quality Assurance ..................... . . . . 16

5.7 Decontamination and Decommissioning . . . . . . . . . . . . 17

5.8 Operating Personnel and Services . . . . . . . . . . . . . 17

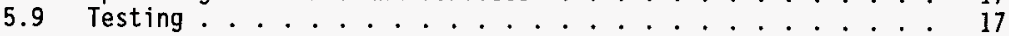

6.0 CODES AND STANDARDS . . . . . . . . . . . . . . . . . . . 18

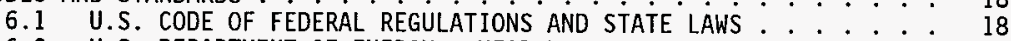

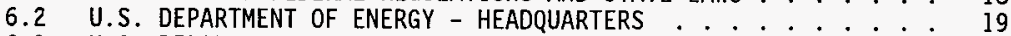

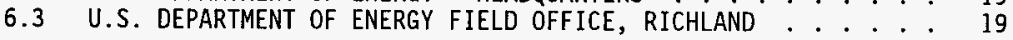

7.0 REFERENCES ......................... . . . . 20

8.0 ACRONYMS AND ABBREVIATIONS . . . . . . . . . . . . . . . . . . . 21

APPENDIX

A. LOCATION ASSESSMENT OF VERTICAL CALCINER . . . . . . . . . . . . . A-1

B. TECHNICAL ASSESSMENT OF THE PFP VERTICAL DENITRATION CALCINER . . . . B-1 
WHC-SD-CP-FDC-003, Rev 0

Page 4 of 21

PFP SOLUTION STABILIZATION

\subsection{INTRODUCTION}

\subsection{Background}

The Hanford Site has completed its production mission and is now beginning its new mission of environmental restoration. Part of the new mission is to stabilize and suitably store or dispose of all plutonium-bearing material.

In response to this mission, the Defense Nuclear Facilities Safety Board (DNFSB) Recommendation 94-1, dated May 26, 1994, made recommendations that resulted in the generation of the Hanford Site Integrated Stabilization Management Plan (SISMP). This SISMP covers the stabilization and storage or disposal of plutonium-bearing material in inventory at the Westinghouse Hanford Company-operated facilities at Richland, Washington and those materials (nonwaste) arising from terminal cleanout of Hanford Site facilities.

For stabilization considerations, all plutonium-bearing materials at the Hanford site have been grouped into categories, one of which is approximately 4,800 Titers of solutions.

For solutions which are not discardable, the baseline plan is to utilize a denitration process to stabilize the solutions prior to packaging for storage, contingent upon the issuance of a Record of Decision for the PFP Stabilization Environmental Impact Statement.

The Environmental Impact Statement (EIS) is expected to recommend that the solutions be treated thermally. and stabilized as a solid for long term storage.

\subsection{Scope}

This document addresses remediation of the $335 \mathrm{~kg}$ of plutonium contained in 4,800 1iters of solutions currently in inventory at the Plutonium Finishing Plant (PFP). This inventory includes:

- Product Plutonium nitrate: These solutions are from the PRF and PUREX processes. This solution is contained in Product Receiver (PR) cans and needs no pretreatment.

- Concentrated filtrate solution: These solutions are contained in PR cans. Some lab testing has indicated that these solutions may need pretreatment using ion exchange or some other pretreatment process to remove extraneous substances prior to processing.

- Flush solutions: Lab testing has also indicated that these solutions 
may need pretreatment due to uncertain composition. These solutions may have elevated levels of sodium, iron, nickel, or chromium which may be removed using ion exchange prior to processing.

The product form for the stabilized solutions will be plutonium oxide fired to the temperature $\left(950^{\circ} \mathrm{C}\right)$ necessary to meet the DOE standard, DOE-STD-3113-94, for 50-year storage.

\subsection{Justification}

The intent of this project is to provide compliance with the Defense Nuclear Facilities Safety Board Recommendation 94-1, dated May 26, 1994 and the Plutonium Vulnerability Management Plan (PVMP) released by the Department of Energy in March 1995. In response to the DNFSB and PVMP, Hanford established the SISMP for stabilization and safe storage of plutonium-bearing material. Initial startup of the solution stabilization phase is anticipated in July 1997. Stabilization of the solutions is projected to be completed in January 1999. The SISMP preliminary schedules show completion of stabilization processing, repackaging, and storage of all materials in the year 2002.

\subsection{Site Location}

The system will be installed at the PFP facility in the 200 West area of the Hanford Site approximately 30 miles northwest of Richland, Washington. The specific location of a new glovebox (230-C-2) containing the solution stabilization system is in Room 230C in the 234-5Z Building. The work is inside the secure area of PFP. Installation will not disturb virgin ground.

The processing system requires a significant amount of floor space because of equipment separation mandated by criticality safety considerations. The following specific site factors, as specified in the Location Assessment for Vertical Calciner, WHC-SD-CP-TI-200 (see Appendix A), were considered in locating the solution stabilization processing system :

- criticality safety,

- Minimization of operator exposure resulting from background radiation levels and vapors (as low as reasonably achievable) [ALARA],

- security and safeguards,

- cost of installation of new equipment,

- availability of the conveyor system for product removal,

- ease of instatlation of the equipment,

- access to storage vessel 1 iquid retrieval station, and

- availability of plant services. 


\subsection{Project Integration}

The project will be installed in PFP during the period of time that PFP is proceeding with implementation of 94-1 activities. This project shall coordinate its design and installation with the active facility and ongoing stabilization processes. The project shall minimize interference with the completion of other 94-I PFP activities or safe maintenance of the PFP facility. Physical interfaces are:

1. The plutonium transfer line from the batch tanks located in glovebox 227T/S

2. Utilities and services located in room $228 \mathrm{~A}$ and $230 \mathrm{C}$

3. Conveyor $\mathrm{HC}-3$ located in room $230 \mathrm{C}$

4. Fire detection, alarm, and suppression system for PFP

5. Liquid waste disposal drain line(s) to 2412 and/or $243 Z$

6. Gloveboxes $\mathrm{HC}-7 \mathrm{C} /$ or equivalent and $\mathrm{HC}-9 \mathrm{~B} /$ or equivalent located in room $228 \mathrm{~A}$

7. Glovebox HA-46F/or equivalent located in room 232

8. Chiller equipment located in the duct level in the 234-5Z Building.

This will provide convenient tie-ins to existing utilities and the conveyor system for product removal. Location shall minimize interferences with other equipment and processes.

Personnel required to operate the solution stabilization process/equipment will not require additional restrooms, changerooms, lockers, etc... No personnel services are provided by this project. Personnel services within the PFP compound are available to personnel working on this system. 
WHC-SD-CP-FDC-003, Rev 0

Page 7 of 21

\subsection{FUNCTIONAL DESIGN CRITERIA}

\subsection{General Guidel ines}

Plutonium-bearing solutions will be processed in a solution stabilization system designed to produce nonreactive plutonium oxide in preparation for dry storage. The system design must:

- be resistent to corrosion from nitric acid, and possible trace amounts of hydrochloric and hydrofluoric acid in some feeds,

- maintain a solution feed rate of 4 liters per hour operating on dilute feedstock, or 600 grams per hour plutonium, operating on rich feedstock,

- be inherently criticality preventing under any credible conditions,

- minimize solid and liquid waste, both in hazard and quantity,

- be modular in design to allow ready replacement of its subcomponents.

\subsection{Component Design Life}

The component design life will vary according to the specific components. Storage tanks are expected to last the length of the existing campaign. Components subject to thermal stresses during processing may have a 3-6 month operating lifespan. The design life of the heater and bearings is 6 months minimum with the entire operation less than 2 years. The heaters are high temperature performance heaters and will likely operate at their temperature limit. The design shall allow easy replacement of items expected to have a shorter operating lifespan.

\subsection{Materials}

Materials shall be compatible with the exposed radiological and chemical environment. Installed materials shall be resistant to radiation, process solutions, acid and caustic vapors and solutions.

Materials exposed to high temperatures shall be chosen for their strength, thermal conductivity, resistance to corrosion, and thermal stress cracking. Materials exposed to high temperatures shall be fabricated from type 310 stainless steel, or a similar stainless steel with high temperature properties.

\subsection{Required Availability}

The solution stabilization system shall be designed for continuous operation. 


\subsection{Operability and Maintainability}

Installation of the solution stabilization system shall provide a safe, efficient system for personnel to operate and maintain. The principles of human factors engineering shall be considered throughout the design of the stabilization system. Instrumentation and controls shall have the capability of monitoring and controlling all parameters necessary for operations. Spacing of the equipment shall provide service and operational needs. The design shall utilize standard components that are currently utilized and readily available as spares. 
WHC-SD-CP-FDC-003, Rev 0

Page 9 of 21

\subsection{PROCESS CRITERIA}

\subsection{Instrumentation and Control}

Al1 instrumentation and controls necessary to monitor and control operation of the stabilization system shall be installed in the 234-5Z Building. The process system controls will be incorporated into the computer furnace control system in room $230 \mathrm{~A}$ and/or be contained in a modular unit installed in Room $230 \mathrm{C}$.

The software utilized by the controller for the operation of the calciner and pre-treatment operations shall be developed, acquired and used in accordance with WHC-CM-4-2, Quality Assurance Manual, Section QR 19.0 "Software Quality Assurance Requirements". The control configuration shall be documented and verified as described in QR 19.0.

The software acceptance test procedure shall be performed by PFP Facilities Engineering personnel and the results documented in an Acceptance Test Report. Functional field tests and an Operational Test Procedure shall exercise all hardware and software components utilized in the performance of the process with the results demonstrating acceptance performance reported in a WHC Supporting Document.

\subsection{Piping and Vessels}

Piping and tubing will be stainless steel material. Vessels will be of corrosion resistant materials such as glass or stainless steel. Feed tanks will be made of glass to meet the main safety criteria for visual inspection of the feed for a separate organic phase.

\subsection{General Process}

The solution stabilization system will be used to convert plutonium nitrate/filtrate/flush solutions into a stable, storable plutonium oxide powder. The conversion is accomplished by a denitration based system as described in the Technical Assessment of the PFP Vertical Denitration Calciner, WHC-SD-CP-TA-009 (See Appendix B), which separates the plutonium out of the solutions and stabilizes the residue at a temperature of nominally $1000^{\circ} \mathrm{C}$. Depending on the feed quality the following two processing options are available:

- direct denitration without any pre-treatment,

- pre-treatment of the feed by ion exchange or EIChrom processes followed by direct denitration of the plutonium.

The solution stabilization process strategy used will minimize introducing additional chemicals into the system.

\subsection{General Mechanical Processes}

The overall solution stabilization system is designated Safety Significant 
(old Safety Class 3 ) and consists of a series of gloveboxes housing tanks, reactors, scrubbers, columns, pumps, and piping interconnected by encased Pu feed and return 1 ines, and chemical lines. These gloveboxes are attached to PFP utility services, the PFP fire protection system, and the PFP ventilation systems.

The individual basic processes to be performed are the transfer, pretreatment, and conversion processing of plutonium-bearing solutions.

The transfer process includes transfers of:

- Pu feed stored in shipping/storage containers (PR cans or L-10 type containers) in Hood $\mathrm{HC}-227 \mathrm{~T}$ to tanks in glovebox $\mathrm{HC}-227 \mathrm{~S}$,

- Pu nitrate solutions from Glovebox $227 \mathrm{~S}$ to the pretreatment process located in glovebox $\mathrm{HC}-7 \mathrm{C} /$ or equivalent and to the new conversion glovebox in room $230 \mathrm{C}$,

- Pu nitrate from the pretreatment process to the conversion glovebox,

- liquid wastes from the processes to the storage tanks in $241-Z$ through the existing PFP waste system (required tie-ins will be included as a part of the project),

- chemical transfers from the chemical makeup area in 234-5Z to the required locations (required tie-ins will be included in the project).

The pre-treatment process will be an ion exchange or EIChrom process consisting of glass tanks, pumps, piping and existing equipment located in $\mathrm{HC}-$ $7 \mathrm{C} /$ or equivalent and support equipment in gloveboxes $\mathrm{HC}-9 \mathrm{~B}$ and $\mathrm{HA}-46 \mathrm{~F}$ (or equivalent).

The conversion process will convert the Pu nitrate solution into a solid that is directly suitable for storage or may require additional thermal processing to meet storage specifications.

The major process components of the system are:

- A closed loop cooling system capable of handling the induced heat loads of the process.

- Two gloveboxes to independently house the conversion process components (a new glovebox provided by PFP) and the pretreatment components located in an existing glovebox ( $\mathrm{HC}-7 \mathrm{C})$.

An encased $\mathrm{Pu}$ transfer 1 ine from glovebox 2275 to the pretreatment and the conversion process gloveboxes including valving and hydrotest capabilities. 
- Ion exchange columns and support tankage and pumps in the pretreatment glovebox. Maximum reuse of existing equipment is encouraged.

- A conversion system, thermal based, to convert the Pu nitrate to a solid including scrubbers,.. product collectors, separators, run tankage and waste collection equipment.

The system will be secured to preclude the contents from contributing to an on or offsite release in the event of a DBE.

If the system utility requirements are in excess of the PFP utility capabilities the project will make the necessary upgrades to provide a fully functional system

\subsection{FACILITY CRITERIA}

\subsection{Architectural and Civil/Structural}

\section{$N / A$}

\subsection{Ventilation}

Ventilation for gloveboxes utilized in the process shall exhaust to the 291-Z-1 stack through two existing testable HEPA filtration stages. In addition a HEPA filtration stage will be installed at the glovebox discharge point for new gloveboxes being installed. The ventilation of the gloveboxes is Safety Significant (o1d Safety Class 3) until the first set of testable filters in the duct level. There are no changes being made to the HEPA filters which are Safety Class (old Safety Class 1). Glovebox supply air will be provided by connecting to the existing Remote Mechanical (RMC), ventilation system. Room ventilation requirements are unchanged. An evaluation will be required to ensure the existing supply air drawn into the gloveboxes from the room through HEPA filters by the glovebox negative pressure will provide sufficient air flow to maintain air temperatures within process and fire protection requirements. All nuclear grade filtration equipment and components will be constructed to American Society of Mechanical Engineers (ASME) N509 and tested to requirements of ASME N510.

\subsection{Utilities}

Utility support services which are available or can be made available are:

- Chiller water in and out,

- Chemical solutions in,

- Liquid waste system out,

- Feed system in (encased line from glovebox HC-227S to new conversion process glove box and pretreatment glovebox), $26 "$ - Hg. process vacuum line and/or a new vacuum system,

- Instrument/process air in, 
- $17^{\prime \prime}$ vacuum system for CAMs/or new CAM exhaust system.

Except for installing a self-contained chilled water supply unit in the duct level, if required, all the utility support services above only entail piping connections to existing plant headers and drains. Standard.

Utility support services shall comply with Glovebox Fire Protection

\subsubsection{Electrical}

The power for the stabilization unit and its related equipment shall be normal power only, supplied from building power panels located in the project area.

The electrical design shall be in compliance with the 1996 edition of the National Electrical Code (NFPA 70).

\subsubsection{Lighting}

The lighting for the stabilization unit installation and operation will be provided by the existing building lighting system. Any additional task lighting will be determined and added by definitive design. Temporary lighting for construction will be provided on an as needed basis.

\subsection{Communications Systems}

Communications will be installed in the Room $230 \mathrm{C}$ operating area, as required. These will include a Private. Automatic Exchange (PAX) phone for internal use, and a public telephone, and a tie-in to the PFP TOA talk-box system.

\subsection{Automatic Data Processing}

Any automatic data processing desired will be incorporated into the system operating control system, as required. Data removal will be by diskette for subsequent analysis.

\subsection{Energy Conservation}

\section{$N / A$}

\subsection{Maintenance}

The stabilization system will be designed to permit routine maintenance activities and reduce the need for specialized equipment wherever practical and cost effective. The system shall minimize exposure to hazardous or radioactive environments. ALARA practices shall be used in all maintenance activities. 


\subsection{GENERAL REQUIREMENTS}

\subsection{Safety \\ 5.1.1 Criticality}

The system shall be designed, fabricated and operated to remain sub-critical. Since there is a potential for critical concentrations of fissile material in the system a criticality analysis shall be provided. All equipment, vessels, and piping shall be geometrically favorable to prevent criticality. Program/project designs shall conform to the requirements listed in WHC-CM-4-29, Nuclear Criticality Safety Manual, Section 2.0.

Criticality prevention is maintained by: geometrically favorable process equipment, spacing the stabilization processing equipment appropriately inside the gloveboxes with adequate separation between components and piping. A criticality drain shall be properly sized and installed in the bottom of the gloveboxes (no sumps) to meet OSR limits on the amount of $\mathrm{Pu}$ in the gloveboxes. All criticality design parameters shall be defined in the Criticality Safety Evaluation Report (CSER) that shall be developed in conjunction with the equipment design.

\subsubsection{Safety Analysis}

The current PFP Final Safety Analysis Report (FSAR) provides the release analysis and limits for plutonium possession in the facility. The addition of the stabilization process does not change the possession limits. Criticality limits to be applied to the project do not affect the PFP FSAR accident bases. The survival of the glovebox(es) to a Design Basis Earthquake (DBE) assures no addition of plutonium to the environmental release beyond that previously analyzed in the accident scenarios. Descriptive changes to the text of chapters 5 and 6 of the FSAR shall be completed by PFP personnel prior to acceptance of the completed project.

The inclusion of criticality drains will require the addition of the drain(s) to the PFP Operational Safety Requirement (OSR) WHC-SD-CP-USR-010 documentation. This shall be completed prior to acceptance of the project.

\subsubsection{Contamination Contro1}

Contamination control will be in accordance with PFP procedures. An additional source of vacuum to support continued operation of the continuous air monitors (CAMs) will be provided when the 17" vacuum is inoperable. 


\subsubsection{Shielding}

Where necessary, shielding shall be provided to reduce personnel radiation exposure levels to ALARA as governed by 10CFR835, "0ccupational Radiation Protection" and DOE/EV/1830.T5, "A Guide to Reducing Radiation Exposure to As Low As Reasonable Achievable (ALARA)".

\subsubsection{Industria7 Safety}

Hazards involved in this project will be eliminated or reduced through implementation of the WHC Safety and Health Standards, procedures and policies, WHC-CM-1-10 Safety Manual. In addition to common construction hazards, work involving electrical circuits will be in accordance with section 15 "Electrical Work Safety" and section 16 "Electrical Installation Safety" of the Safety Manual. As part of the PFP readiness assessment a job hazard walkdown shall be performed by PFP Industrial Safety Engineers.

\subsubsection{Industria] Hygiene}

The design and construction shall assure compliance with applicable industrial health and safety standards (29 CFR's 1910 and 1926), WHC-CM-440 and WHC-CM-1-11, and the most recent consensus standards applicable to occupational safety and health (e.g. ACGIH Threshold Limit Values for Chemical Substances and Physical Agents and Biological Exposure Indices)

\subsubsection{Fire Protection}

Glovebox fire protection systems shall be designed in accordance with DOE/RLID 5480.7, "Fire Protection"; Glovebox Fire Protection Standard, Draft Report, prepared for U.S. Department of Energy by Westinghouse Hanford Company, March 1993; and applicable NFPA standards.

\subsubsection{Traffic Safety}

No traffic modifications are envisioned as part of this project.

\subsection{Environmental Protection and Compliance}

A Notice of Construction (NOC) shall be prepared and submitted to the Washington State Department of Health prior to operation of the solution stabilization system. All work that will be performed that has the possibility of radiological or non-radiological emissions shall be brought to the attention of the PFP air emissions engineer.

All liquid waste that is anticipated or generated during solution stabilization shall be reviewed by the PFP liquid effluents engineer.

All solid waste that will be generated during installation and operation of the solution stabilization equipment shall be reviewed by the PFP solid waste 
engineer.

Tanks and piping systems designed for waste disposal will be reviewed by PFP Environmental Engineering to ensure compliance with applicable requirements of the Resource Conservation and Recovery Act (RCRA).

National Environment Policy Act (NEPA) documentation shall be prepared and approved prior to installation and operation of the solution stabilization system. The Plutonium Finishing Plant Stabilization Environmental Impact Statement will be the NEPA documentation for the operation of the solution stabilization system. Installation of the solution stabilization system will need to be reviewed for the appropriate level of NEPA documentation.

The cultural resource review has been completed. The Memorandum of Agreement to mitigate the historical significance documentation for the Plutonium Finishing Plant complex has been approved by the Department of Interior.

\subsection{Safeguards and Security}

The processing of Special Nuclear Material requires physical protection as outlined in the Department of Energy orders, DOE 5632.1C "Protection and Control of Safeguards and Security Interests".

The 94-1 Stabilization Project Vulnerability Risk Analysis, WHC-96-00015, was performed using the DOE approved theft and sabotage scenarios. With the addition of the following security upgrades, the Risk Analysis determined that the physical protection of room $230-C$ is acceptable for the stabilization process. The security boundary limits are defined by the following:

- the South wa11s and doors of room 227, 228A, B, C, 230A, B, C, and that portion of the south wall of 235B which adjoins Rooms 234 and $234 \mathrm{~A}$,

- the West walls and doors of rooms $230 \mathrm{C}$, and $235 \mathrm{~B}$,

- the North walls and doors of 235B, 230A, B, 228A, B, C, and 227,

- the East wall of room 227.

The security upgrades required for 230-C but not part of this project consist of the following:

The interior of the room will be monitored by volumetric intrusion sensors. These sensors will detect any unauthorized access to the target materials within the room.

Doors 638 and 639 will be monitored by Balanced Magnetic Switch (BMS) sensors to detect unauthorized use of these doors.

Closed Circuit Television (CCTV) cameras will be used for surveillance of target areas. A Security Police officer will be dispatched to assess sensor alarms.

Authorized access into this area will be controlled by a positive 
identification device (a hand geometry unit) that will require a "two person rule". The two person rule requires that at least two knowledgeable people in the Personnel Security Assurance Program are in the area when work is in progress.

\subsection{Natural Forces}

The PFP Facility is a Hazards Class 2 facility. The gloveboxes and process that is installed by this project will deal with Category l quantities of fissile material. The PFP FSAR, WHC-SD-CP-SAR-021, contains restrictions un the quantities of Plutonium that may be released in a seismic event. Other natural phenomena events do not effect the accident analysis contained in the PFP FSAR. The glovebox(es) containing the plutonium bearing equipment shall be restrained to survive a DBE of $0.2 \mathrm{~g}$ as described in the FSAR. The equipment in the glovebox(es) that could jeopardize the confinement capabilities of the glovebox(es) shall be restrained. The gloveboxes are classified as Safety Significant equipment but the analysis method applied for the determination of restraint requirements shall be of the same type as applied to Safety Class equipment. Supporting equipment external to the glovebox(es) shall not impact the integrity of the glovebox(es). All other equipment shall be secured as required by the UBC in effect at the time of construction. The project is within the analyzed bounds of the PFP Authorization Basis.

\subsection{Design Format}

Drawings that interface with existing PFP facility drawings shall provide traceability to these existing drawings by identifying the affected WHC drawings in accordance with WHC-CM-6-3, Drafting Standards Manual.

Modifications which affect the accuracy or completeness of any Essential Drawing identified in WHC-SD-CP-TI-125, PFP Essential and Support Drawing List, shall require that revision of the affected Essential Drawing be completed by the Project.

Equipment Component Identifier numbers designated for new equipment shall be defined in accordance with WHC-SD-CP-RD-024, Component Identifying Standard for the PFP.

\subsection{Quality Assurance}

Qual ity Assurance and Quality Control services shall be provided for design specification, design media, materials procurement, fabrication, installation and acceptance testing activities. Requirements imposed by and derived from 10CFR830.120 shal1 be implemented using a graded approach to assure that customer requirements are met and that the final installation will perform as the designers intended.

These Reviews, Inspections, and other 0versight services shall be supplemented with any additional services defined by the designers and fabricators as being essential to assuring the success of their efforts. 


\subsection{Decontamination and Decommissioning}

The system shall be designed to limit dispersion of radioactive materials, and facilitate decontamination and decommissioning or reuse. All readily accessible surfaces should be finished (ground, polished, painted with Amercoat, etc.) to facilitate decontamination. Components should be designed for easy disassembly using common tools, to the extent practical. Disassembled components should be small enough to be easily handled using sealouts and compact enough to fit in some disposal package such as a 55 gallon drum.

\subsection{Operating Personnel and Services}

A control operator interface will provide all process parameters and controls to an individual location, as much as practical. This location will be within view of the conversion glovebox for security reasons but in a location to Timit personnel exposure to As Low As Reasonably Achievable (ALARA). The establishment of radiological areas with in the room that would allow for access to the workstation without Personal Protective Equipment (PPE) shall be considered in determining placement. The interface/workstation shall be ergonomically correct and shall be sealed to allow for easy decontamination.

All valves should be positioned such that the valve can be seen during manipulation. All equipment must be accessible from glove ports to allow for maintenance. As much as possible, valving shall be consolidated in a minimal number of gloveboxes to expedite operations.

The solution stabilization glovebox shall have a seal-in/seal-out port 1 arge enough to support parts replacement of equipment plus additional means for introduction of small equipment (sphincter port).

Both PAX and normal phone lines shall be present at the control interface/workstation. Computer Local Area Network (LAN) access shall be evaluated and determined by PFP Process Engineering.

\subsection{Testing}

- The stabilization system will be tested with cerium nitrate which is the standin material for plutonium nitrate. This non-radioactive material al lows for easy correction of deficiencies that would not be possible with the use of Plutonium nitrate. This is part of the Acceptance Test Procedure (ATP)/Operational Test Procedure (OTP) phase of acceptance testing. 


\subsection{CODES AND STANDARDS}

In general, applicable Occupational Safety and Health Administration standards, and the "national consensus" codes and standards as developed by such organizations as the American Society of Mechanical Engineers, and the American National Standards Institute shall be used.

The design and construction of the stabilization system shall comply with the current versions of the following codes and standards:

- American Conference of Government Industrial Hygienists (ACGIH)

- American Society of Mechanical Engineers (ASME)

- Environmental Protection Agency (EPA)

- Institute of Electrical and Electronics Engineers (IEEE)

- Instrument Society of America (ISA)

- National Fire Protection Association (NFPA)

- National Electrical Code (NFPA 70)

- National Environmental Policy Act (NEPA)

- National Emissions Standards and Hazardous Air Pollutants (NESHAP)

- Resource Conservation and Recovery Act (RCRA)

- Uniform Building Code (UBC).

A11 applicable DOE orders and standards in effect at the start of the design and all Federal, State, and local laws and regulations shall apply to the extent specified in S/RID (WHC-SD-MP-SRID-003).

\subsection{U.S. CODE OF FEDERAL REGULATIONS AND STATE LAWS}

- $\quad 10$ CFR 830.120, "Nuclear Safety Management Quality Assurance".

- 10 CFR 835, "Occupational Radiation Protection".

- 29 CFR 1910, "Occupational Safety and Health Standards".

- 29 CFR 1926, "Safety and Health Regulations for Construction".

- 40 CFR 262, "Standards Applicable to Generators of Hazardous Waste".

- Washington Administrative Code (WAC) 173-303-170, "Dangerous Waste Regulations". 
WHC-SD-CP-FDC-003, Rev 0

Page 19 of 21

\subsection{U.S. DEPARTMENT OF ENERGY - HEADQUARTERS}

- Department of Energy DOE-STD-3013-94, "Criteria for Safe Storage of Plutonium Metals and 0xides".

- Department of Energy DOE/EV/1830.T5, "A Guide to Reducing Radiation Exposure to As Low As Reasonable Achievable (ALARA)".

- Department of Energy DOE/EM/0199, "Plutonium Vulnerability Management Plan".

- Department of Energy Order 5632.1C, "Protection and Control of Safeguards and Security Interests".

\subsection{U.S. DEPARTMENT OF ENERGY FIELD OFFICE, RICHLAND}

- Department of Energy-Richland Operations Order RL HSRCM-1, "Hanford Site Radiological Control Manual".

- Department of Energy-Richland Operations Implementing Directive (RLID) 5480.7, "Fire Protection".

- Department of Energy-Richland Operations Implementing Procedure (RLIP) 4700.1A, Attachment $V-l$, "Functional Design Criteria". 


\subsection{REFERENCES}

- WHC-96-00015, 94-1 Stabilization Project Vulnerability Risk Analysis

- WHC-CM-1-10, Safety Manual

- WHC-CM-1-11, Industrial Hygiene Manual

- WHC-CM-4-29, Nuclear Criticality Safety Manual

- WHC-CM-4-40, Industrial Hygiene Manual

- WHC-CM-4-46, Safety Analysis Manual

- WHC-CM-6-1, Standard Engineering Practices

- WHC-CM-6-3, Drafting Standards Manual

- WHC-CM-7-5, Environmental Compliance Manual

- WHC-EP-0853, DNFSB Recommendation 94-1 Hanford site Integrated Stabilization Management Plan.

- WHC-IP-1026, Engineering Practices Guidelines

- WHC-SD-CP-OSR-010, PFP Operational Safety Requirement

- WHC-SD-CP-RD-024, Component Identifying Standard for the PFP

- WHC-SD-CP-SAR-021, PFP Final Safety Ana7ysis Report

- WHC-SD-CP-TA-009, Technical Assessment of the PFP Vertical Denitration Calciner

- WHC-SD-CP-TI-125, PFP Essential and Support Drawing List

- WHC-SD-CP-TI-200, Location Assessment of Vertical Calciner

- WHC-SD-MP-SRID-003, PFP Standards/Requirements Identification Document 


\subsection{ACRONYMS AND ABBREVIATIONS}

$\begin{array}{ll}\text { ALARA } & \text { As Low As Reasonably Achievable } \\ \text { BMS } & \text { Balanced Magnetic Switch } \\ \text { CAM } & \text { Continuous Air Monitor } \\ \text { CCTV } & \text { Closed Circuit Television } \\ \text { CSER } & \text { Criticality Safety Evaluation Report } \\ \text { DBE } & \text { Design Basis Earthquake } \\ \text { DNFSB } & \text { Defense Nuclear Facilities Safety Board } \\ \text { DOE } & \text { Department of Energy } \\ \text { FSAR } & \text { Final Safety Analysis Report } \\ \text { HEPA } & \text { High Efficiency Particulate Air } \\ \text { LAN } & \text { Local Area Network } \\ \text { NOC } & \text { Notice of Construction } \\ \text { OSR } & \text { Operational Safety Requirements } \\ \text { PAX } & \text { Private Automatic Exchange } \\ \text { PFP } & \text { Plutonium Finishing PTant } \\ \text { PRF } & \text { Plutonium Reclamation Facility } \\ \text { PPE } & \text { Personal Protective Equipment } \\ \text { PRV } & \text { Pressure Reducing Valve } \\ \text { Pu } & \text { Plutonium } \\ \text { PVMP } & \text { Plutonium Vulnerability Management Plan } \\ \text { RMC } & \text { Remote Mechanical C } \\ \text { SDR } & \text { Supplemental Design Requirement } \\ \text { SISMP } & \text { Site Integrated Stabilization Management PTan } \\ \text { WHC } & \text { Westinghouse Hanford Company }\end{array}$


WHC-SD-CP-FDC-003, Rev 0

Page A-1 of $A-32$

APPENDIX A 


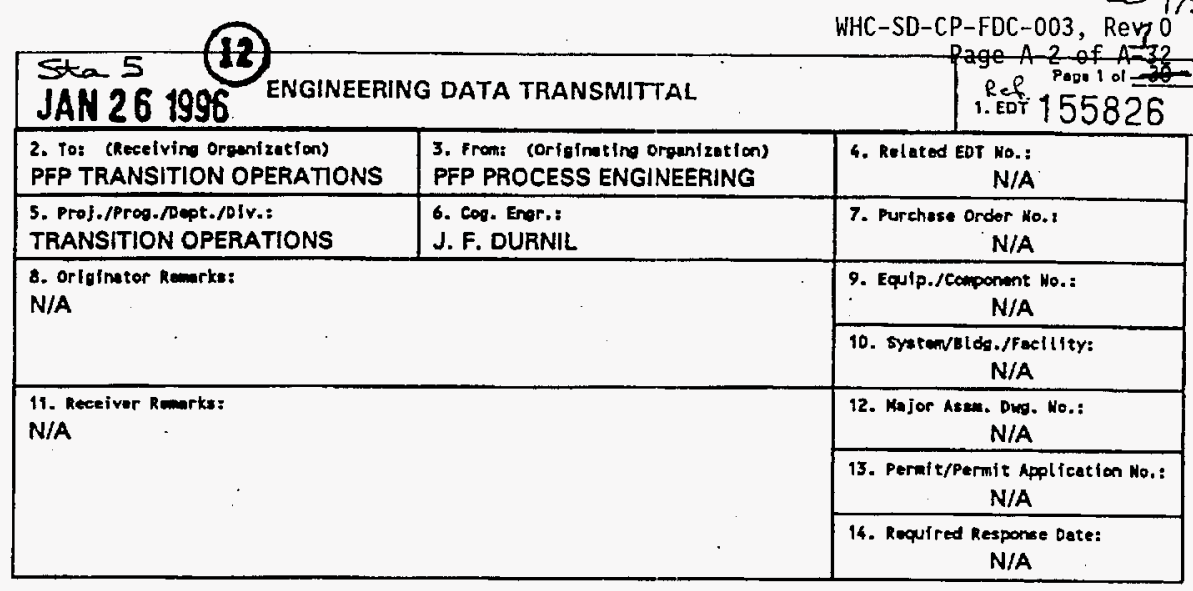

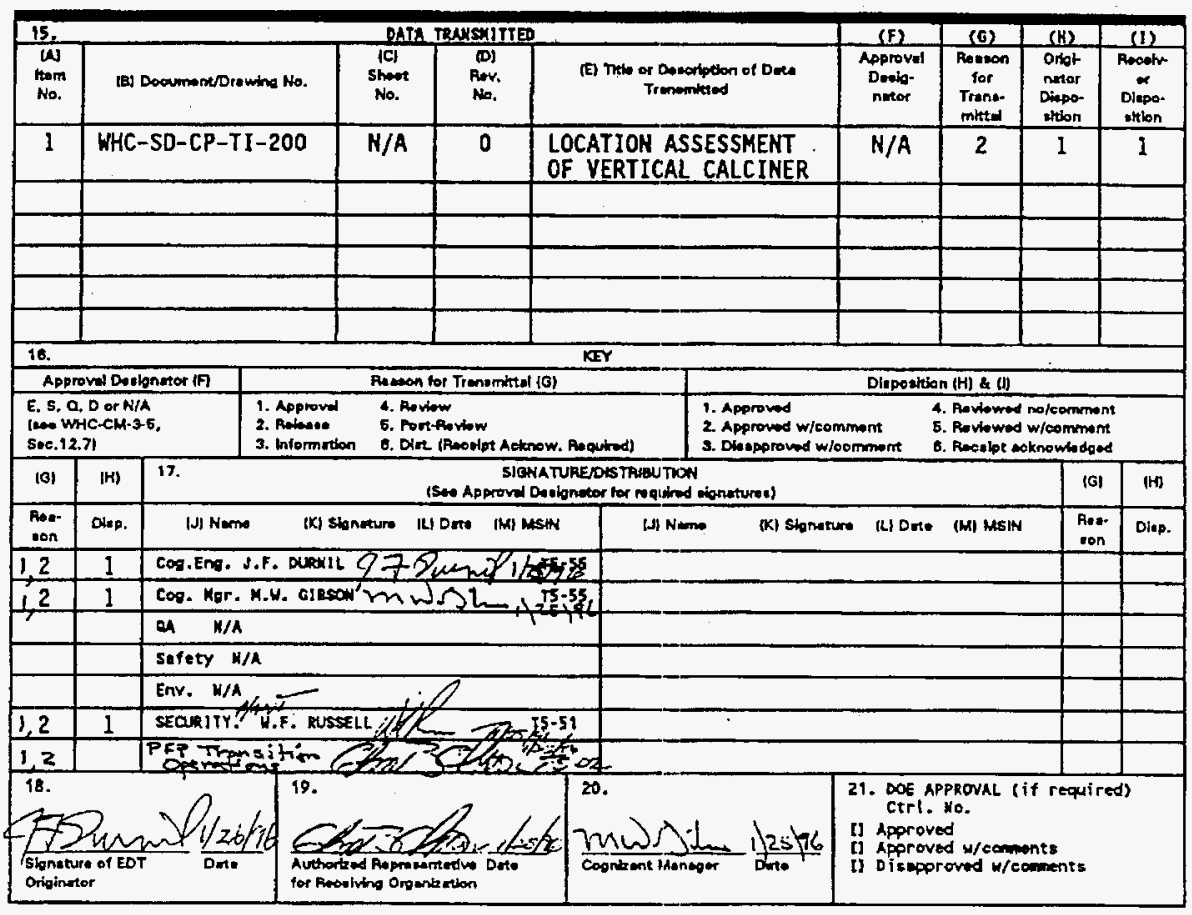

60-7400-972-2 (0/949) GEF097 


\section{LOCATION ASSESSMENT OF VERTICAL CALCINER}

J. F. DURNIL \& S. B. DUTTA

WESTINGHOUSE HANFORD CO., Richland, WA 99352

U.S. Department of Energy Contract DE-HCO6-87RL10930

EDT/ECH: 155826

UC:

Org Code: 15530

BaR Code:

Charge Code: $K 6137$

Total Pages: 30

Key Words: PFP, PLUTONIUH, PU, SOLUTION, STABILIZATION, 94-1, CALCINER, DENITRATOR

Abstract: Possible locations inside PFP were examined for installing a vertical calciner systen to stabilize plutonium solutions to satisfy part of the 94-1 DNFSB recomendation. The recommended location would be a new glovebox to be installed inside Room 230-C in the Plutonium Finishing Plant (PFP).

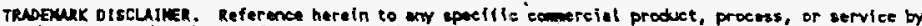

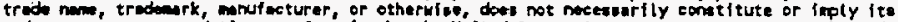
endorament, recomendition, or favorine by the United stated Goverrment or any agency thereof or ite contrectors or subeontrictors.

Printed in the thited states of Nerice. To abedin capies of this document, contact: Whe/BCs Document control services, P.0. tex 1970, Mallstop W6-100, Richlend un 99352, Phone (509) 372-2420; Fax (509) 376-4999.
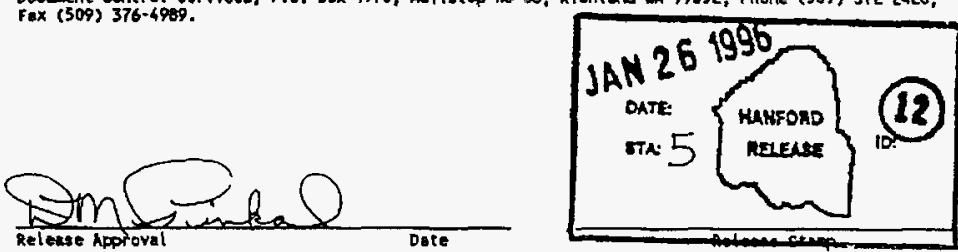

Approved for Putlic Release

A-6400-073 (10/95) DEF321 


\section{TABLE OF CONTEMTS}

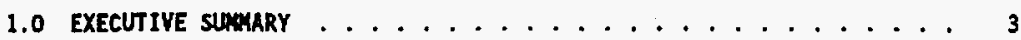

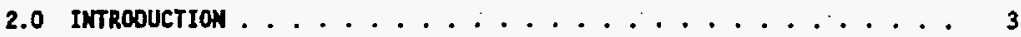

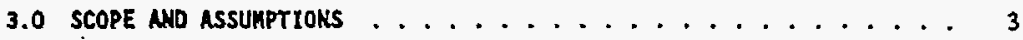

4.0 METHODOLOEY ......................... 6

5.0 EVALUATION OF GLOVEBOXES . . . . . . . . . . . 6

5.1 DESCRIPTION OF THE GLOVEBOXES ............. 9

5.2 COHPARISON OF THE GLOVEBOXES $\ldots \ldots \ldots \ldots$

5.2.1 Criticaltty Safety: . . . . . . . . . . 10

5.2 .2 AlARA . . . . . . . . . . . . 11

5.2.3 Security and safeguards: ............ 12

5.2 .4 cost Estimation: . . . . . . . . . . . 12

5.2 .5 Access to Conveyor system: . . . . . . . . . . 13

5.2 .6 Ease of Installation: . . . . . . . . . . . 13

5.2.7 Access to Llquld Retrieval station: ........ 14

5.2 .8 Avallability of plant Services: ......... 14

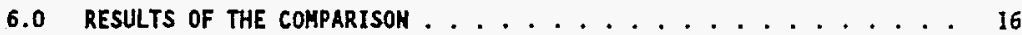

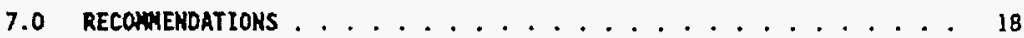

8.0 ISSUES TO BE RESOLVED . . . . . . . . . . . . . 19

APPEKDIX A - ALARA ASSESSMENT . . . . . . . . . . . . 25

APPEHDIX \& - CRITICALITY ASSESSMENT . . . . . . . . . . 25

APPEROIX $\mathrm{C}$ - SAFEGUARDS AND SECURITY ASSESSHEMT $\ldots \ldots \ldots \ldots \ldots$

APPENOIX D - IMSTALLATIOH COST ASSESSMENT . . . . . . . . 28

FIGURE 1 - CALCIMER PROCESS FLOK DIAGRAY . . . . . . . . . 20

FIGURE 2 - BLOCK SCHEKATIC OF YERTICAL CALCINER SYSTEM . . . . . 21

FIGURE 3 - LOCATION OF GLOVEBOX HC-7C NND THE PROPOSED NEW GLOVEBOX : : 22

FIGURE 4 - GLOVEBOX HC-TC . . . . . . . . . . . . 23

FIGURE 5 - KEH GLOVEBOX $\ldots \ldots \ldots \ldots \ldots \ldots \ldots \ldots$

TABLE 1. GLOVEBOXES CONSIDERED FOR VERTICAL CALCINER . . . . . . . 8

TABLE 2. PLANT SERVICES . . . . . . . . . . . 15

TABLE 3. COAPARISON OF HC-7C AND THE HEV GB $(230-\dot{C}-2) \cdots \ldots \ldots \ldots$ 


\subsection{EXECUTIYE SUMARY}

The possible locations for a vertical calciner in the Plutonium Finishing Plant (PFP) 234-5Z building were identified and compared. This assessment determined that a new glovebox in room $230 \mathrm{C}$ is the best location for the vertical calciner based on the assumptions and weighing factors as described in this report.

\subsection{INTRODUCTION}

Plutonium bearing process solutions at the Plutonium Finishing Plant (PFP) need to be stabilized for long term storage. A vertical calciner (see Flgures 1 and 2 for a process flow diagram and 2 block schematic of the system) will use a direct denitration process to stabilize this material. The Plutonium Process Support Laboratory (PPSL) has a pilot scale vertical calciner that has completed cold testing and is now undergoing hot testing with solutions from the PFP. Approximately $15 \mathrm{~L}$ of radioactive solution have been fed to the pilot scale vertical calciner as of January 1996 with minor observable process problems.

The purpose of this location assessment is to study possible locations for the production scale vertical calciner at the PFP and give recommendations as to which location should be used.

\subsection{SCOPE AND ASSUKPTIOHS}

The 94-1 solutions to be processed in the vertical calciner include the following:

1) Product Plutonfum nitrate solution from the Plutonium Uranium Extraction Facility (PUREX) and Plutonium Reclamation Facility (PRF) processes. This solution is contained in Product Receiver (PR) cans (100 items with $250 \mathrm{~kg}$ total PU) and needs no pretreatment.

2) Concentrated filtrate solution contained in PR cans (180 items with $40 \mathrm{~kg}$ total Pu). Laboratory technical evaluation has indicated that these solutions will need pretreatment by ion exchange to remrove the potassiunl (which could affect the quality of the calcine produced) prior to sending the solution to the calciner.

3) Flush solutions contained in PR cans and L-10 type containers (150 items with $50 \mathrm{~kg}$ total $\mathrm{Pu}$ ). Laboratory testing has also indicated that these solutions will probably need pretreatment due to uncertain composition. These solutions have unacceptably high levels of sodium, iron, nickel, or chromium, which would be 
removed by ion exchange before processing the solution through the calciner. The fon exchange pre-treatment system will probabily be designed and operated to route uranium in those fiush items containing uranium to the plutonium rich eluant stream.

Potential locations for pretreatment are partilaliy constrained by the location of the vertical calciner. In this location assessment for the vertical calciner, the selection process did not preciude any areas where the pretreatinent process may be located.

Figure 3 has potential locations for the vertical calciner and the pretreatment process. The details and locations for the pretreatment process cannot be defined untll additional laboratory testing is done on pretreatment methods. This information is not expected before March 1996 and decisions made on whether pretreatment is required and what unit operations are recommended.

The draft Environmental Impact Statement (EIS) recommended that the above solutions be treated thermally and stabilized to a solid for long term storage. The draft EIS did not recomend ariy specific location of the treatment facility.

The gioveboxes in the PRF area were not considered as potential sites for the vertical calciner process as the projected Terminal clean Out (TCO) of that area will be performed at the same time as the projected operation of the vertical calciner. The gloveboxes in the Remote Mechanical A (RMA) 7 ine were not considered a potential site for the vertical calciner process due to very high dose rates in most of the RMA line area. Those areas that are accessibie (RMA fabrication area - rooms $235 \mathrm{~B}$ and C) contain only gloveboxes that are being used for other processes with the exception of glovebox HA-19 which is too small for vertical calciner installation.

The gloveboxes in rooms 230A, B, and C (RMC line fabrication area) were not considered for vertical calciner instaliation as they are being used for other processes (thermal stabllization in muffle furnaces, etc.). (Glovebox HC-60 is in standby condition for caustic hydrolysis processing.)

The gloveboxes in the RHC Line were evaluated as a potentlal site for the vertical calciner process (preferred due to one additional wall between the process area and the non-radiological area for containment control in the case of an abnormal occurrence). Also, the RHC Line process area was recently operated (1988 - 89) for metal production.

The scope of this document is to evaluate the identified gloveboxes from the areas discussed above. These gloveboxes have been identified as having the necessary space (approximately 6 feet high by 11 feet long by 3 feet wide) to accomodate the calciner and the associated process equipment.

The vertical calciner is 4 feet 6 inches tall with additional clearances for maintenance and has a diameter of 6 inches, nomina 1,16 inches with 
insulation. The remaining tanks are 6 inches in diameter with the following

length for each one: feed recelving tank 24 to 30 inches, feed pump tank 24 to 30 inches, flush tank 12 inches, scrubber waste tanks 6 feet, and vacuum trap 18 to 24 inches.

The criticality spacing between equipment is given beiow.

The following assunptions were made:

1) The maximum diameter (excluding insulation) of the equipment inside the glovebox is 6 inches, nominal.

2) The spacing (criticality prevention) between each piece of equipment is about 18 inches and the spacing between the inside edge of the glovebox and any piece of equipment is about 8 inches. With insulation, the outside diameter of the calciner is approximately 16 inches.

3) The cost of connecting lines from plant air, reagent tanks (caustic solution, etc.), electrical, process waste iine, and the of fgas (to existing process vacuum) to the equipment inside the glovebox will be similar for all the Identified gloveboxes.

4) The calciner product w1ll be collected in the calciner glovebox and be sent to the product storage vault: without being thermaliy stabilized in the muffle furnaces. If the vertical calciner temperature cannot be maintained at $1000^{\circ} \mathrm{C}$, then the product will go to the muffle furnaces.

5) A new, dedicated, closed loop water chilling unit will be installed near the glovebox. This unit should probabily be installed in the PFP duct level, to reduce the amount of equipment installed in probable contamination areas (CA's).

6) The feed will be transferred from the staging tank (an intermediate tank used to store feed after pretreatment prior to sending it to the vertical calciner process) to the feed tank inside the calciner glovebox.

7) The storage container liquid retrieval ( $P R$ can and other container unloading) station will be at $\mathrm{KC}-227 \mathrm{~S} / \mathrm{T}$.

8) The scrubber process offgas will be routed into the existing PFP process vacuum (26" $\mathrm{Hg}$ vacuum) system.

9) The glovebox exhaust ventilation and process vessel vent will be routed to the existing PFP E-4 filter room(s) (Rooms $309 \& 310$ ), through an existing filter box, via E-4 HVAC piping in the duct level. 
10) The scrubber waste from the collection tanks will be connected to a drain line which will route plant liquid wastes to TK-D8, 241-Z.

11) The caustic solution line will be brought down from the Room 337 (top level) to the duct level and then will be connected to the scrubber inside the glovebox.

12) The glovebox should be tall enough to allow enough space for maintenance which will allow lowering the heater and feed tubing, and disassembling and removing the calciner agitator from above.

13) The glovebox should have a greater than 18 inch air lock or seal in port.

\subsection{METHODOLOGY}

The selected gloveboxes will be compared in the following areas which are iisted in order of relative importance.

1) criticality safety,

2) ALARA,

3) security and safeguards,

4) cost of instaliation of new equipment (estimated),

5) avallability of the conveyor system for product removal,

6) ease of installation of the equipment,

7) access to storage vessel liquid retrieval station, and

8) avallability of plant services.

\subsection{EVALUATION OF GLOVEBOXES}

There are a number of existing gloveboxes in the Plutonium Finishing Plant (PFP) facility which could be selected for installation of the vertical calciner.

The existing gloveboxes in the following areas were not considered for installation of the vertical calciner:

1) Existing gloveboxes in the Plutonium Reclamation Facility (PRF) area were not considered as a potential site for the vertical calciner process because Teminai Clean Out (rCO) of that process area is projected to overlap vertical calciner operation. 
2) Existing gloveboxes in the Remote Mechanical $A$ (RMA) 1 ine area were not considered as potential sites for the vertical calciner process due to very high dose rates in this area.

Those RMA line areas with a lower dose rate (RHA fabrication area rooin 2358 and $C$ ) have gloveboxes being used for other processes, with the exception of glovebox HA-19 which is too small for vertical calciner installation.

3) Existing gloveboxes in Roons 230A, B, and C (RMC fabrication area) were not considered as potential sites as these gloveboxes are being used for other processes (thermal stabilization in muffle furnaces, etc.). Glovebox HC-60 in room 230C was nat considered due to the floor between the top and bottom sections which would require cutting holes in the floor for the installation of the vertical calciner equipment." Glovebox HC-60 is in standby condition for caustic hydrolysis processing or. it may be used for solids handling during terminal clean out.

The gloveboxes in the RAC Line were evaluated for the installation of the vertical calciner.

The vertical calciner system requires a significant amount of floor space because of equipinent separation mandated by critfcality safety considerations. The vertical denitrator and supporting equipment require a glovebox which has the following recomended size: 11 feet long by 3 feet wide by 6 feet high.

The RMC line gloveboxes 1 isted in Table 1 were considered for installation of the vertical calciner process. Host of the gloveboxes considered were eliminated from use based on size constraints. 
TABLE 1, GLOYEBOXES COKSIDERED FOR YERTICAL CALCINER

\begin{tabular}{|c|c|c|c|c|}
\hline Glovebex & Drmeneions & Locat ion $\ln 234-52$ & Sfeecial features & Further Consideration \\
\hline HC-7 & $80^{4} \mathrm{~L} \times 31 \times \times 91$ & 20002234 & tunable vesuel. & YeA \\
\hline HC- 98 & 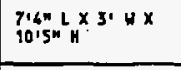 & 20002284 & $\begin{array}{l}\text { Extre floors } \\
\text { vplitting } \\
\text { flovedex }\end{array}$ & Yee \\
\hline ke- 10 & 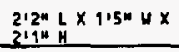 & noom 2284 & & No \\
\hline$a c-11$ & 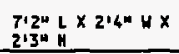 & Room 2284 & & Ho \\
\hline HC. 125 & $\begin{array}{l}2170 \pm \times 2124 \cup x \\
315=y\end{array}$ & Rocan 2288 & & No \\
\hline HC- 1360 & $\begin{array}{l}3+201 \times 2 \times 1110 \mathrm{~V} \\
\times 4+100 \mathrm{H} \\
\end{array}$ & Roon 2280 & & No \\
\hline HC- 15 & 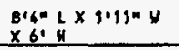 & Roon 2288 & & No \\
\hline$K C \cdot 16 C C$ & 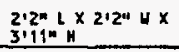 & Rocm 2288 & & No \\
\hline He-17DC & $\begin{array}{l}31100 \mathrm{~L} \times 212^{\prime \prime} \\
\times 415 \mathrm{~m} \times \\
\end{array}$ & Room 2280 & & No \\
\hline HC- $17 \mathrm{P}$ & $\begin{array}{l}21002 \times 212114 \\
\times 645+11 \mathrm{H} \\
\end{array}$ & $\operatorname{Rocm} 22 \Delta c$ & & No \\
\hline $\mathrm{HC}-1758 \mathrm{~B}$ & $\begin{array}{l}517010 \times 110 * 4 \times \\
2110^{\circ} \times\end{array}$ & Room $228 c$ & & Wo \\
\hline Hew & ${ }_{61}^{151} \mathrm{~L} \times 31644 \times$ & 20002300 & Wo contentination & Yes \\
\hline
\end{tabular}


Those gloveboxes receiving further consideration (1arge enough) for installation of the vertical calciner are $H C-7 C$, $H C-9 B$, and a new glovebox (tentatively identified as 230-C-2) which would be installed in Room 230-C.

The exterlor dimensions of glovebox $\mathrm{HC}-9 \mathrm{~B}$ indicated that the glovebox could contain the vertical calciner equipment. However, the interior of glovebox HC-9B is separated into three horizontal sections (floors), none with sufficient height to accommodate the calciner or the other equipment (scrubber, etc.). This would require cutting hole(s) into its interior floor $(s)$. Also, there are several significantly contaminated areas below the glovebox $\mathrm{HC}-9 \mathrm{~B}$ exterior shielding (lead and lead glass). These reasons precluded glovebox $H C-9 B$ from further considerition.

Glovebox HC-7C has sufficient space to hold the vertical calciner equipment (with the exception of the waste collection tanks). Also, an uncontaminated new glovebox at the PFP has sufficient space to hold all of the vertical caiciner equipment.

Therefore, glovebox HC-7C and the new glovebox will be considered for installation of the vertical calciner.

In the following subsections, these gloveboxes ( $\mathrm{HC}-7 \mathrm{C}$ and the new one) will be evaluated on the basis of the criteria described above in the methodology section.

Room $230 C$ has been chosen as the probable location of the new glovebox (230-C-2) which would contain the vertical calciner. This room was selected for consideration based on the accessibility of the conveyor system and a security upgrade for themal stabilization processing in progress.

\subsection{DESCRIPTION OF THE GLOVEBOXES}

Glovebox HC-7: The overall size of this glovebox is 8 feet long $\times 3$ feet deep and 9 feet 10 inches high. See Figure 4 or drawing no. H-2-19260 for details. There is sufficient space to install

all the equipment inside this glovebox with the exception of the two scrubber waste collection tanks. These two collection tanks would be installed in glovebox $\mathrm{HC}-9 \mathrm{~B}$. Glovebox $\mathrm{HC}-7 \mathrm{C}$ contains contaninated equipment including tanks, pipelines, tubing, tubing fittings, valves, piping fittings, and instrument connections.

Hew Glovebox: The overall size of the proposed new glovebox is 15 feet long $\times 3$ feet 6 inches deep and 6 feet high. See Figure 5 or drawing no. H-4-109252, sheet 1 for details. This glovebox is completely empty and all the new calciner equipment will fit into it. 


\subsection{COMPARISON OF THE GLOVEBOXES}

The gloveboxes were conpared based on the following areas:

1) criticality safety,

2) ALARA,

3) security and safeguards,

4) cost estiration (installation of vertical calciner,

5) access to conveyor system,

6) ease of installation,

7) access to liquid retrieval station, and

8) availability of plant services.

Each of these areas is discussed in detail in the following subsections.

5.2.1 Criticality Safety: Criticality prevention is maintained by: 1) geometrically favorable process equipment, 2) spacing the vertical calciner equipment 18 inches apart inside the glovebox with 8 inches of separation from the equipment and the walls of the glovebox, 3) a criticality drain in the bottom of the glovebox (no sumps), and 4) OSR. iimits on the amount of Pu (about 8000 grams) in the glovebox.

The size of the process equipment (favorable geometry) will be the same for both the gloveboxes.

Glovebox $\mathrm{HC}-7$ : The criticality spacing requirements will not allow all (waste tanks in another glovebox) of the equipment to be installed in the glovebox. This glovebox has a functional criticality drain. The OSR limit on dispersible plutonium in this glovebox is 3,000 grams. This 1 imit would have to be raised to atrout 8,000 grams as the calciner contains about 6,000 grams during operation pius the $P u$ in the staging tank and the feed tanks. Raising this Timit could probably be overcome; however, there are some significant adninistrative problems associated with changing this number.

New glovebox: The criticality spacing requirements will allow all the proposed equipment to be installed in the glovebox. An OSR 1 imit on dispersible pu would have to be developed for this glovebox. The glovebox will need to have a criticality drafn installed and have the sumps blanked off, filled, or removed. 
5.2.2 ALAR: Glovebox HC-7: There are high contamination levels within glovebox HC-7. Norkers would work in these contamination levels when removing old components and installing new components in this glovebox. Removal of the existing equipment would have the following consequences:

a) There would be approximately 64 cubic feet of radioactive waste generated while cleaning the existing equiprent out of glovebox HC- $7 \mathrm{C}$ which would need to be removed during Decontamination and Decormissioning of the facility,

b) Use of $H C-7 C$ for the calciner would require a larger amount of personnel exposure during removal of the existing equipment and the installation of the new equipment than that required to install the equipment in a new glovebox. Dose rates around $\mathrm{HC}-7 \mathrm{C}$ range from 3 to $12 \mathrm{mrem} / \mathrm{hr}$ while the dose rates at the proposed location for the new glovebox in room $230 \mathrm{C}$ are $<0.5$ to $1 \mathrm{mrem} / \mathrm{hr}$.

If $\mathrm{HC}-7 \mathrm{C}$ is connected to the existing conveyor system, the radiation workers must open the ends of two gloveboxes, build an extenston between them, and install the new conveyor equipment.

If $\mathrm{HC}-7 \mathrm{C}$ were used without a hook up to the existing conveyor system, operators would be expected to receive larger extremity dose during operation. The increased dose would be due to more product handiing time for sea]ing out and transportation. This difference in exposure from $\mathrm{KC}-\mathrm{TC}$ without a conveyor hookup and with a conveyor hookup would be equivalent to one seal out from $H C-7 C$ then a seal in to a conveyor system glovebox with transport to a bag-less seal out system.

The location of Feed storage retrieval station (HC-227S/T) is closer to the glovebox HC-7C (approximately 25 feet). Therefore, running a double encased pipe line from $H C-2275 / T$ to $H C-7 C w 111$ be shorter than running one to the new glovebox. Depending on integrity, the current pipe line from $H C-227 S / T$ to $H C-7 C$ could be used. Horkers irould be exposed to less contamination while running the shorter pipeline (if the pipeline will be run through currentiy contaminated areas) or not at all if the current pipe line can be used.

New Glovebox: Since this glovebox is new, workers would essentially be working in a contamination free area during instaliation of the new equipment. Future product handling time would be minimized since the conveyor system would be connected to this glovebox.

One disadvantage to placing the calciner in a new glovebox is that the location of Feed storage retrieval station (HC-227S/T) is away from the proposed location of new glovebox (Room 230C); therefore, the installation of the double encased pipe line will be longer (approximately $150 \mathrm{ft}$ ). The potential contamination and radiation depend on where the pipeline is run from $\mathrm{HC}-227 \mathrm{~S} / \mathrm{T}$ to the new glovebox. 
A Tong term disadvantage of a new glovebox will be to have one more glovebox added to decontamination and decomission with the associated worker exposure.

The plant services connections to the new glovebox may have some contamination, but it will be insignificant when compared to the removal and instaliation work in glovebox $\mathrm{HC}-7$.

5.2.3 Security and Safeguards: Glovebox HC-7: The location of this glovebox is in room 228A, which is in a protected area. For the $H C-7 C$ glovebox to be used for the vertical calciner, a new Vulnerability Analysis (VA) would need to be done. The security upgrades required as a result of the VA could result in additional motion detection coverage of the new target areas. The conveyor belt hoods in these areas may also need additional barriers. The cost of the analysis and resulting security upgrades could be significant, and the cost cannot be determined untif the new VA is complete.

New glovebox: If this glovebox is installed in room $230 \mathrm{C}$ with the vertical calciner in it, a new Vulnerability Analysis (VA) would not need to be done, since this proposed glovebox is part of the security upgrade designs currently underway. Therefore, no cost or schedule impacts are expected.

5.2.4 Cost Estimation: The cost estimation was done as part of the comparison of the two gloveboxes under consideration ( $\mathrm{HC}-7 \mathrm{C}$ and the new one). The cost estimate for glovebox $\mathrm{HC}-\mathrm{TC}$ included the removal of existing equipment, reusing some of the existing equipment, and installing the new equipment. The cost estimate for the new glovebox only included the installation of the equipment into this glovebox and the installation of the glovebox into room $230 \mathrm{C}$. The cost estimation was not done for the total cost of the entire project.

The estimated cost for installing the system in the new glovebox is $\$ 500,000$ less than installing the same system in $\mathrm{HC}-7$. This difference is discussed below and detalied in Appendix $D$.

Glovebox HC-7: The estimated overall cost: for the removal of contaminated equipment, reuse of the existing equipment after decontamination, and the installing the new equipment is $\$ 770,000$. For more detailed information, see Appendix-D. Connection of the conveyor system to the glovebox would add extra cost to the installation of the calciner in this glovebox. The design using an existing contaminated glovebox is usualiy $20 \%$ more expensive than an uncontaminated glovebox.

New glovebox: The cost of installing the new vertical calciner equipment into this glovebox is estimated as $\$ 270,000$. For detailed information, see Appendix $D$. The installation of the new equipment in the glovebox wili not require any special precautions. However, the tie-ins to the existing 
process off-gas and glovebox off-gas.will require special precautions. The cost of modifications to this new glovebox (criticality drain, blanking off sump, and new windows) will be in addition to the estinated cost of new equipment instaliation.

5.2.5 Access to Conveyor System: Glovebox HC-7: This glovebox does not have a conveyor system directly connected to it. There is a conveyor system in another glovebox nearby which could be extended to $\mathrm{HC}-7 \mathrm{C}$ or the material could be manually sealed out.

New glovebox: The proposed location of the new glovebox (230-c-2) would be in room $230 \mathrm{C}$ which has an existing conveyor system that can be connected to the glovebox.

5.2.6 Ease of Installation: Glovebox HC-7: To accomodate the new calciner equipment, the following equipment needs to be removed:

1) Filter kill tank,

2) Filtrate storage tank,

3) Filtrate catch tank,

4) less than 100 Linear feet of piping and tubing and its accessories.

The following existing equipment can be used to support the system:

1) The staging feed tank can be substituted by the existing Pre-Reduction tank (PRT) with moderate piping changes.

2) The feed tank can be substituted by the existing Transfer head tank, with minor piping changes.

3) The Aqueous Collection tank and the Flush tank can be used to support the calciner system.

The existing contaminated equipment needing removal will be bagged out and disposed off as contaminated waste. This equipment must have the residual liquid drained and must be flushed prior to removal. Utilizing the existing equipment as mentioned above will require the same follow up procedure for draining and flushing.

The interfor surface of this glovebox and the existing equipment are contaminated. Precautionary steps to prevent the spread of contamination need to be taken during the removal of the unnecessary equipment, the reuse of the existing equipment, and installation of the new equipment. This work will be done under contamination prevention control and thus will require a longer time to accomplish than an uncontaminated glovebox as the potential for the spread of contamination exists. 
The availabllity of a nearby control room could be satisfied by using the RKC Itne control room since it contains shielding and viewing windows of this glovebox.

Hew Glovebox: This glovebox is free from any contamination and equipment. The new process equipment can be installed without the removal of equipaient and no contamination controls.

The availability of a near by control room could be satisfied by using the existing one in room $230 \mathrm{~A}$.

5.2.7 Access to Liquid Retrieval Station: The glovebox HC-7C is close (25 $\mathrm{ft}$ ) to the storage retrieval station while the new glovebox would require a longer (150 ft) encased piping connection.

5.2.8 Avallabtlity of Plant Services: Glovebox $\mathrm{HC}-7 \mathrm{C}$ and the new glovebox: The plant services connections are available (see Table 2 ). The installation of the plant service connections to either glovebox would not have any potential difference in cost estination. The electrical power connection to either of these gloveboxes would be done by either running the line from the transformer sitting at the duct level or installing a new electrical control panel cabinet in the roon itself. Therefore, this would not have any impact on the comparison.

Glovebox HC-7C and the new glovebox need the following plant service connections:

1) Chiller water in and out,

2) Caustic solution in,

3) Waste system out,

4) Feed system in (encased ine from giovebox $\mathrm{HC}-227 \mathrm{~S} / \mathrm{T}$ ),

5) $26^{n}-\mathrm{Hg}$. process vacuum line or a new vacuum line out, and

6) Process air in. 
TABLE 2. PLAT SERYICES

\begin{tabular}{|c|c|c|c|}
\hline ITEMS & 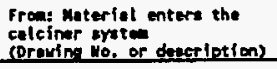 & 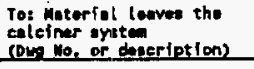 & REMURKS \\
\hline $\begin{array}{l}\text { Pure solut fon } \\
\text { Loed-in }\end{array}$ & $\begin{array}{l}\text { At } \mathrm{nC}-227 \mathrm{~s} / \mathrm{T} \text {, } \\
\text { Load-in GT's or RT's }\end{array}$ & $\begin{array}{l}\text { Staging versel inside } \\
\text { glombox }\end{array}$ & $\begin{array}{l}\text { Ow. No, H-2-26104, } \\
\text { K-2-26910 installod } \\
\text { equip. plaine hods nec. }\end{array}$ \\
\hline Food to Calciner & $\begin{array}{l}\text { steging tunk Inatde the } \\
\text { glovetox }\end{array}$ & Product reciefiver. & \\
\hline $\begin{array}{l}\text { Process Alr } \\
\text { (celefner) }\end{array}$ & $\begin{array}{l}\text { From nosder in the Duct } \\
\text { Ievel }\end{array}$ & Process off gas stron & \\
\hline Chllled beter & $\begin{array}{l}\text { soparate chiller inetalled } \\
\text { cloes to glovebox }\end{array}$ & Weter retirn to chiller & $\begin{array}{l}\text { Closed rystem cooling } \\
\text { water wi th heat exchengs } \\
\text { to water or afr }\end{array}$ \\
\hline $\begin{array}{l}\text { ER(KWAC) to E-4 } \\
\text { hesder }\end{array}$ & $\begin{array}{l}\text { noce alr for glovebox } \mathrm{KC}_{7} 7 \text {; } \\
\text { Fre eommor for How Gs }\end{array}$ & alovebox uff-ges atreas & $\begin{array}{l}\text { Owg. No. } 1-2-23400 \text { sh. } 16 \\
\text { (E6) Duct Livel } \\
\text { At the Filter Bax. }\end{array}$ \\
\hline Procest off-ges & $\begin{array}{l}\text { Meinly from Glovebox Air } \\
\text { strem }\end{array}$ & Into 26" Ha vecum system & $\begin{array}{l}\text { Ow. Ho. } \begin{array}{l}H-2-96418 \text { oh. } 12 \\
\text { (Duct (evel) }\end{array}\end{array}$ \\
\hline $\begin{array}{l}\text { Serubber. } \\
\text { Weste }\end{array}$ & $\begin{array}{l}\text { Eran seruber to collection } \\
\text { Tenks in the of (Calciner) }\end{array}$ & $\begin{array}{l}\text { From coll weti on tunke to } \\
241-2 \text { Ildg. (1K=08) }\end{array}$ & Belon Ist. Floor \\
\hline Product pu Oxide & GB(Cslciner) & $\begin{array}{l}\text { Product sea l- ast from } \\
\text { calciner } \mathrm{CB} \text { or furnace } \\
\text { blend gferion area. }\end{array}$ & $\begin{array}{l}\text { From es (Colciner) to } \\
\text { seal-out/blending area } \\
\text { by conveyor. }\end{array}$ \\
\hline Electric power & Source not defined as yet & & \\
\hline Cuvetic solution & $\begin{array}{l}\text { From tark in the top level } \\
\text { Roct } 336 / 337 \text { to dxet level } \\
\text { to ecrutber }\end{array}$ & $\begin{array}{l}\text { Fran ocrutbur to scrubber } \\
\text { weste collewtion tank. }\end{array}$ & Dug.No, H-2-97813 \\
\hline
\end{tabular}

"See Section 8.0 for Issues To Be Resolved. 


\subsection{RESULTS OF THE COHPARISOH}

The results of the comparison are sumarized in Table 3 COMPARISON OF. HC-7C AND THE NEW GLOVEBOX where weighted scores in the eight categories are shown. The Table Indlcates that the new glovebox has a an overall score of 684 and was more favorable in the areas of. ALARA, security and safeguards, cost of installation, availability of conveyor system, and ease of installation (including contamination control). Table 3 also indicates that $\mathrm{HC}-7 \mathrm{C}$ has an overal1 score of 414 and was more advantageous in access to the storage vessel liquid retrieval station. 


\section{TABLE 3. COMPARISON OF HC-7C MRO THE NEN GB (230-C-2)}

\begin{tabular}{|c|c|c|c|c|}
\hline $\begin{array}{l}\text { Arev of } \\
\text { Comerison }\end{array}$ & $M C-7$ & Stcore & How ol orebox & score \\
\hline $\begin{array}{l}\text { Eriticality } \\
\text { sefety. }\end{array}$ & 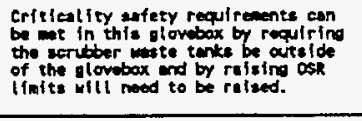 & 120 & 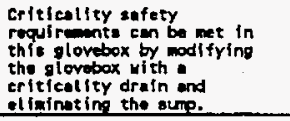 & .135 \\
\hline ALARA & 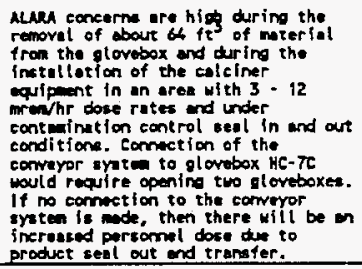 & 65 & 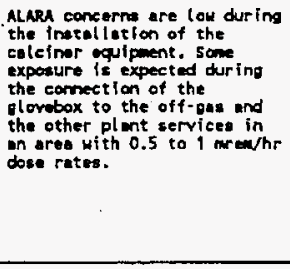 & 120 \\
\hline $\begin{array}{l}\text { Security and } \\
\text { Sefegurds }\end{array}$ & 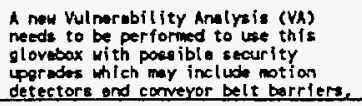 & 40 & $\begin{array}{l}\text { Rocm } 2300 \text { (proposed area of } \\
\text { Instellation) is part of a } \\
\text { securlty uporede and no new } \\
\text { VA neede to be perforned. }\end{array}$ & 100 \\
\hline $\begin{array}{l}\text { Cost } \\
\text { Estination }\end{array}$ & 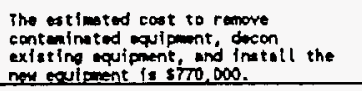 & 45 & $\begin{array}{l}\text { The estimated coet to install } \\
\text { the calciner equipient in the } \\
\text { new slovebox is } \$ 270,000 \text {. }\end{array}$ & 135 \\
\hline $\begin{array}{l}\text { Accese to } \\
\text { Converor } \\
\text { Syetein }\end{array}$ & $\begin{array}{l}\text { No comection to an existina comveyor } \\
\text { system. }\end{array}$ & 6 & $\begin{array}{l}\text { Proposed locktion has } \\
\text { conveyor system to comect } \\
\text { with. }\end{array}$ & 60 \\
\hline $\begin{array}{l}\text { Esse of } \\
\text { Instatlistion }\end{array}$ & 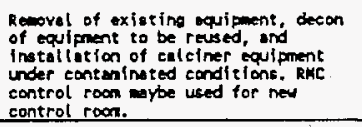 & 18 & 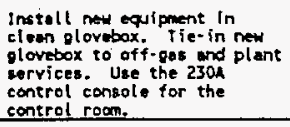 & 48 \\
\hline $\begin{array}{l}\text { Access to } \\
\text { liquid } \\
\text { retrieval } \\
\text { stistion }\end{array}$ & $\begin{array}{l}\text { glovebox is opproxinately } 25 \text { ft avey } \\
\text { from retrieval station. }\end{array}$ & 60 & $\begin{array}{l}\text { Glovebox is opproximately } 150 \\
\text { fe ausy from retrieval } \\
\text { station. }\end{array}$ & 6 \\
\hline $\begin{array}{l}\text { Availability } \\
\text { of plent } \\
\text { servlees }\end{array}$ & $\begin{array}{l}\text { Plant servlees are readily uvailable } \\
\text { (tee Table } 3 \text { for details). }\end{array}$ & 80 & $\begin{array}{l}\text { Plant ervices are readily } \\
\text { uvaileble (see Toble } 3 \text { for } \\
\text { derails). }\end{array}$ & 80 \\
\hline Total seore & & & & 684 \\
\hline
\end{tabular}


Scoring: The above areas in Table 3 were evaluated on a scale of 1 to 10 (10 being a perfect score). Those scores were then multiplied by the following welghing factors

$\begin{array}{lr}\text { Criticality Safety } & 15 \\ \text { ALARA } & 15 \\ \text { Security and Safeguards } & 10 \\ \text { Cost Estimation } & 15 \\ \text { Access to Conveyor } & 6 \\ \text { Ease of Installation } & 6 \\ \text { Access to Liquid Retrieval Station } & 6 \\ \text { Avallability of Plant Services } & 8\end{array}$

The score was then totaled at the bottom of the column.

\subsection{RECOMEENDATIONS}

on the basis of the comparisons and prioritization made in the previous sections between glovebox $H C-7 C$ and the new glovebox, it is recommended that the vertical calciner be installed in the new glovebox.

The location for the new glovebox is in room $230 \mathrm{C}$ of 234-5Z at the end of the existing conveyor system (see Figure 3 ). This location for the new glovebox is recommended due to the following reasons:

1) availability of the conveyor (ALARA considerations),

2) enough space for the operation of the glovebox,

3) plant services are avallable at this location,

4) the process system controls can be added to the computer control system in room $230 \mathrm{~A}$,

5) the security and safeguards upgrade is underway in this room,

6) will allow installation, and modification in a clean environment, and

7) ease of installation of equipment: workers can fully access all areas inside new clean glovebox for welding, fitup, etc, and the whole assembled unit could be moved to the process area as a unit. A waste tie-in point is also nearby this location. 


\section{WHC-SD-CP-FDC-003, Rev 0 \\ Page $A-21$ of $A-32$}

LOCATION ASSESSHENT OF VERTICAL CALCINER

Ref. WHC-SD-CP-TI-200

\subsection{ISSUES TO BE RESOLVED}

Further problem areas affecting the location of the vertical calciner.

1) The actual layout of the waste collection tanks needs to be determined if the system is installed in glovebox $\mathrm{BC}-7 \mathrm{C}$ (waste collection tanks in $\mathrm{HC}-9 \mathrm{~B}$ ).

2) The liquid handling system for pretreatment and the vertical calciner liquid feed handling system needs to be integrated.

3) If the new glovebox HVAC supply air is provided by the conveyor glovebox, then the capacity of the system to supply the air must be determined before the design continues for the connection of the new glovebox.

4) The electrical power supply requirements and source locations must be integrated with the calciner system design. 


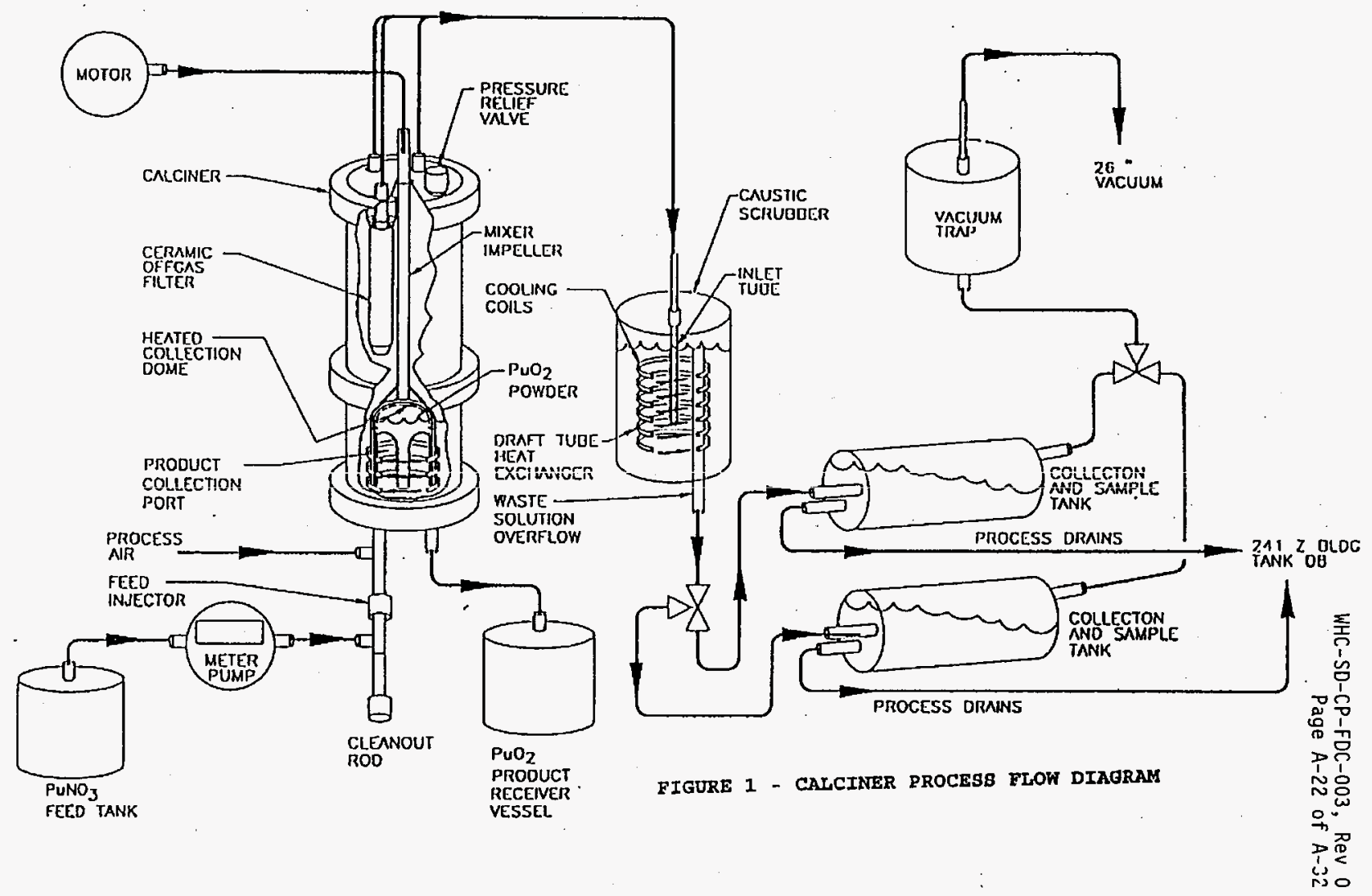


LOCATION ASSESSMENT OF VERTICAL CALCINER

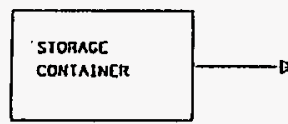

Ref WHC-SD-CP-TI-200

REV. 0, Page 21

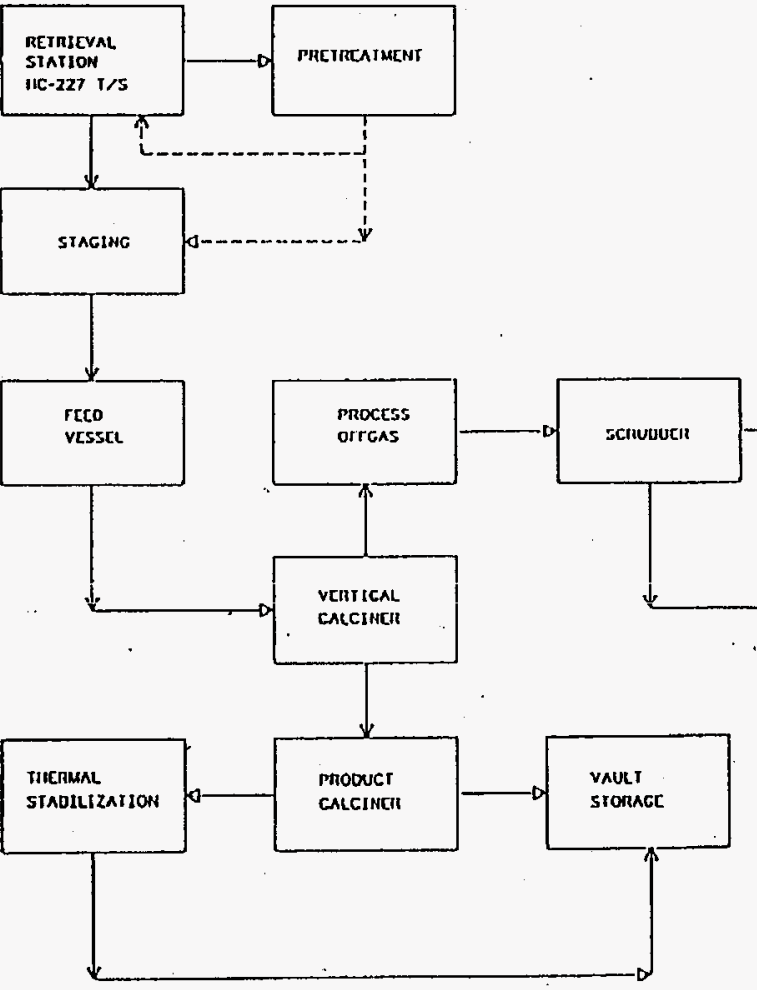

C-4 CXIMUST orrons srsiem

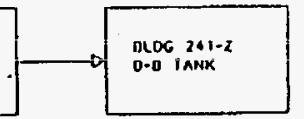

FIGURE 2 - BLOCK SCHEMATIC OF VERTICAL CALCINER SYSTEY 
LOCATION ASSESSMENT OF VERTICAL CALCINER
Ref, WHC-SD-CP-TI -200
REV. 0, Page 22

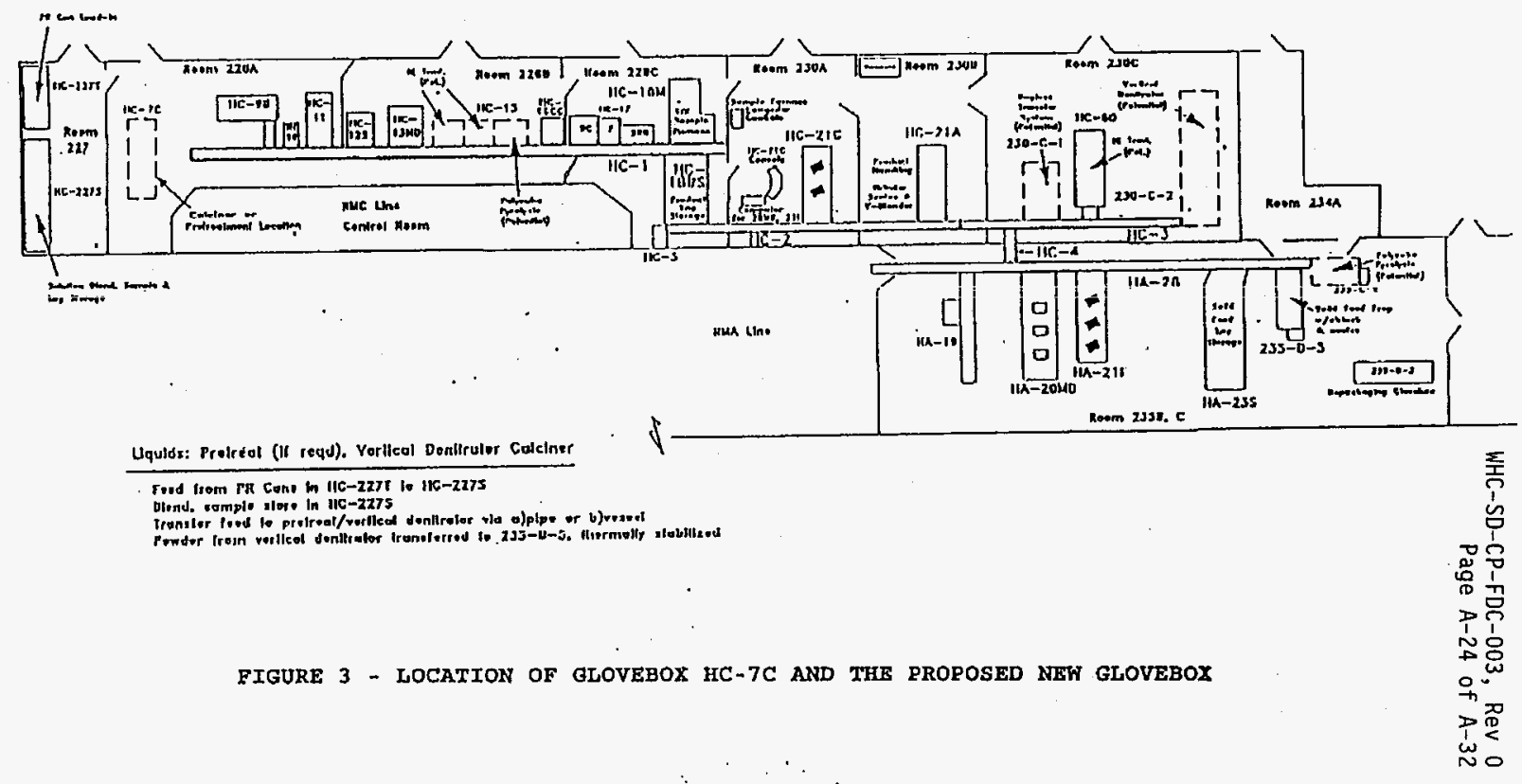


WHC-SD-CP-FDC-003, Rev 0

Page $A-25$ of $A-32$
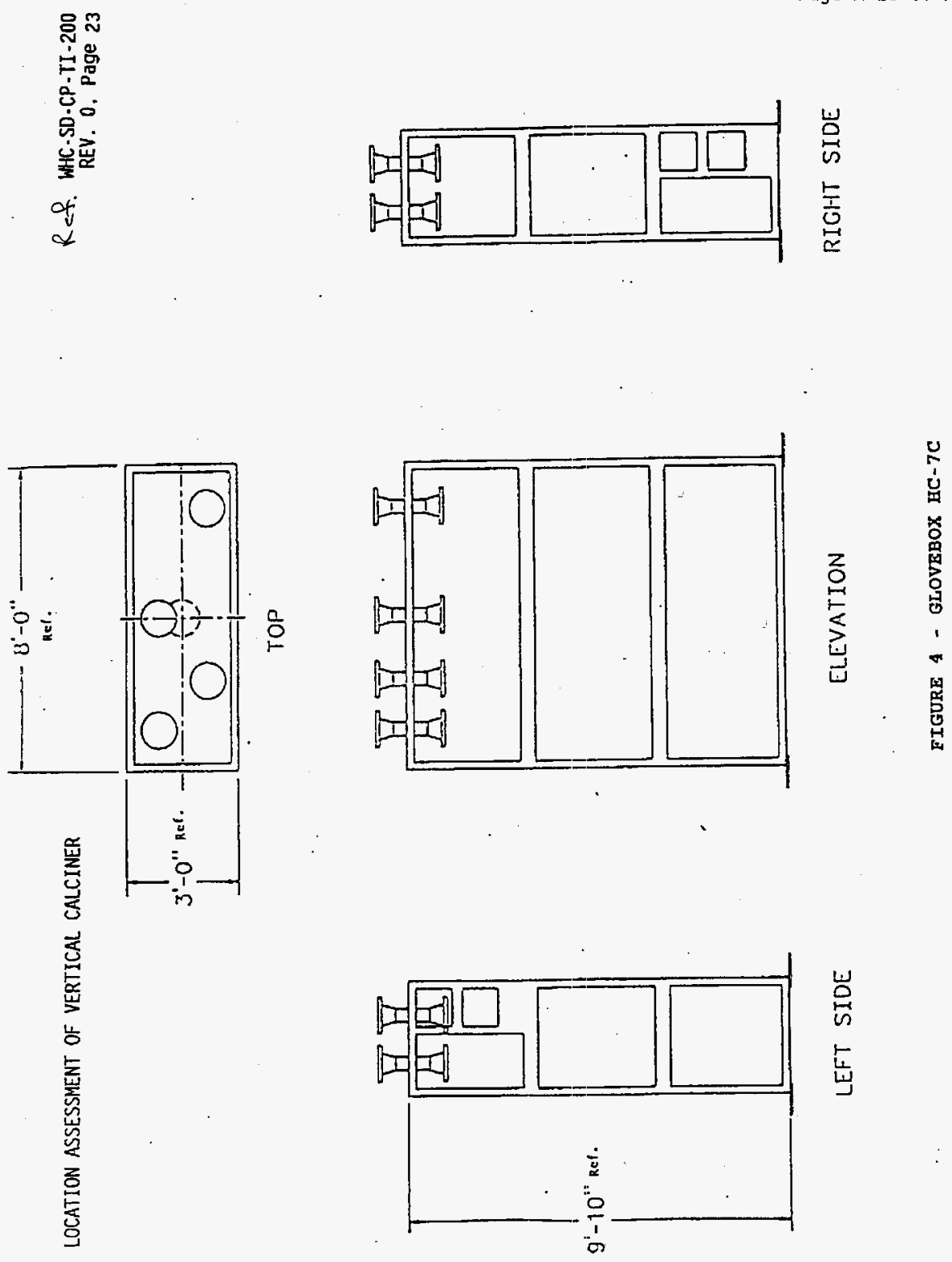

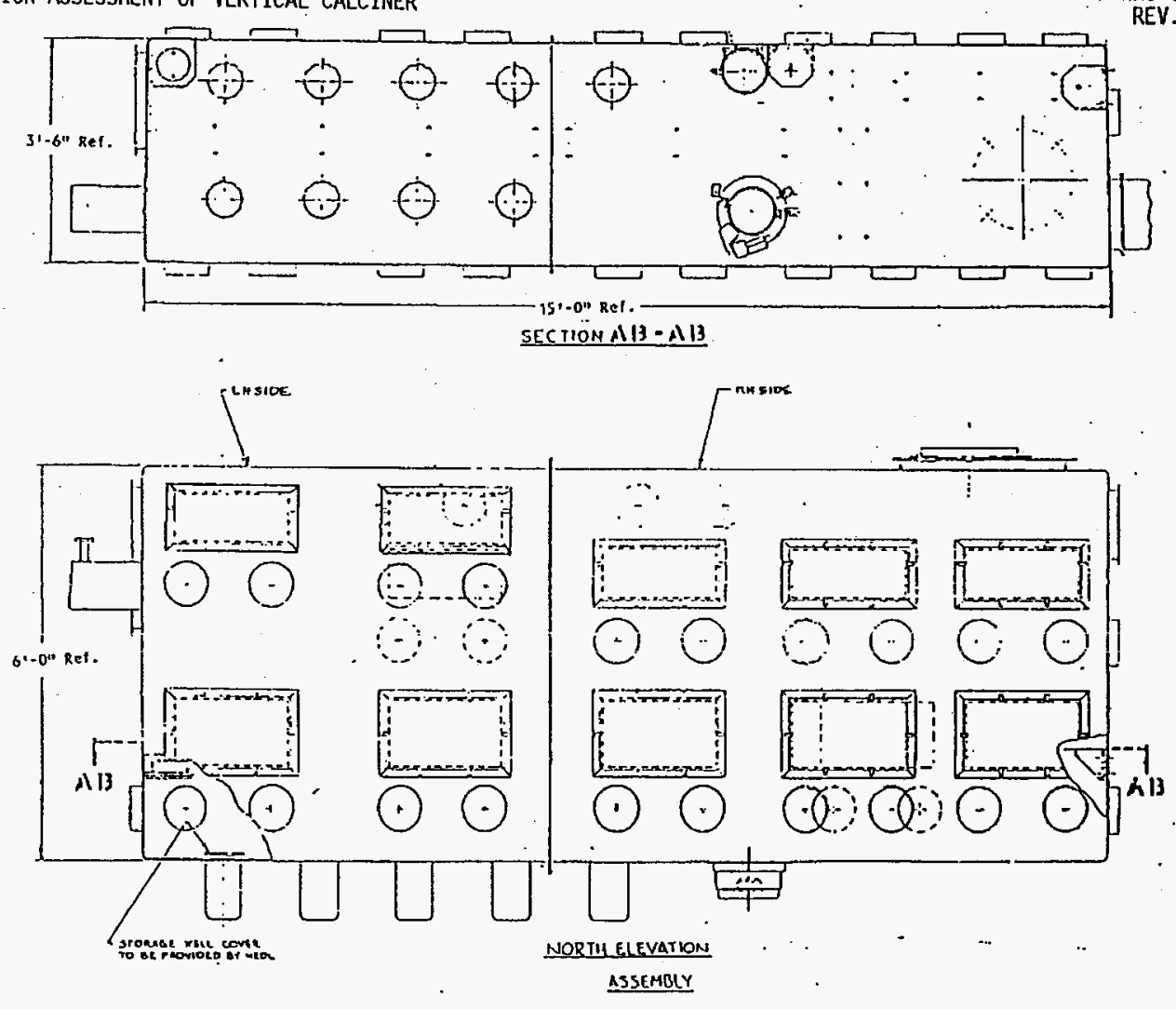

FIGURE 5 - NEW GLOVEBOX 


\section{APPEKDIX A - ALARA ASSESSHENT}

[23] From: Robert B (Rob) Sits]er at -WHC70 12/15/95 12:06PH (3441 bytes: I

in)

To: Satya B Dutta at -WHC246

cc: Robert B (Rob) Sitsler

Subject: Re: ALARA ASSESSHENT

The Assessment was made for glovebox HC-7 (existing)

and the new one.

1) Glovebox $\mathrm{HC}-7$ :

Disadvantage: 1) There will be high contamination levels within HC-7.

Workers would be working in these levels when removing old components and

instaling new components in this glovebox. (a) There would be a great amount of radioactive waste generated whlle cleaning the existing equipment, (b) Use of $\mathrm{HC}-7$ for the calciner would cost PFP a considerably larger amount of personnel exposure. Dose rates around $\mathrm{HC}-7$ range from $3-12 \mathrm{mrem} / \mathrm{hr}$. where dose rates in $230 \mathrm{C}$ are $<0.5-1 \mathrm{mren} / \mathrm{hr}$. 1i) If $\mathrm{HC}-7$ were used without a hook up to the existing conveyor, operators would be expected to receive larger extremity exposures when operation commences. This would be due to more product handing time for sealing in and out and transportation.

Advantage: The location of Feed storage retrieval station (HC-2275) is closer to the glovebox $\mathrm{HC}-7$, so, running the double encased pipe line will be shorter, therefore, workers would be exposed to less contamination while running the pipe line (if pipeline is running through currently contaminated areas).

2) New Glovebox:

Aovantage: Since this glovebox is new, workers would essentially be working in a contamination free area. Future product handling time would be minimized since the conveyor system is connected to this glovebox, product hand ing is minimum.

The only disadvantage to placing the calciner in a new glovebox is that the location of Feed storage retrieval station ( $\mathrm{HC}-227 \mathrm{~S}$ ) is away from the proposed location of new glovebox (Room No. 230C), installing the double encased pipe line will be longer. Therefore, it depending on where the pipeline is run the contamination potential involved with running the pipeline would be greater.

Moreover, the plant services connection may have some contamination, but insignificant when compared to that to work in glovebox (HC-7).

Make a recommendation based on ALARA such as:

Based on ALARA, installation of a new glovebox in $230 \mathrm{C}$

would be the wiser of the two choices. 


\section{APPEDIX B - CRITICALITY ASSESSHENT}

[9] From: Laurren T (Tom) Nirider at -WHC120 11/29/95 10:34AM (1182 bytes: 22 in)

To: Satya B Dutta at WHC246

Subject: $H C-7 C$ Criticality Questions

Message Contents

Satya:

As we discussed this morning, glovebox HC-7C would be appropriate from a criticality safety perspective for vertical calciner operations. There is presently an OSR Timit on dispersible plutonium in HC-7C of 3,000 grams PU. This could probably be overcone, however there are some significant administrative problems associated with changing that number.

HC-7C has a functional criticality drain and so would be safe in that regard. The new FMEF glovebox would need to have a criticality drain installed and have the surps blanked off, fllled, or removed prior to use. As it is a clean glovebox, this should not present significant difficulties.

If you have any questions, please call me.

TON MIRIDER

373-3180 


\section{APPENDIX C - SAFEGUARDS AND SECURITY ASSESSKENT}

n off thdewxta, W F Jr (Bill) Russell at "WHC28, Paul F Klear

Subject: Additional GTove Box in Room 230C

Message Contents

Text item 1: Text_1

Satya,

You asked about the security impacts of additional glove boxes in room $230 \mathrm{C}$. My reply is as follows:

The initial process configuration proposed the addition of one or two glove boxes in room $230 \mathrm{C}$. These were considered as part of the initial risk analysis. I have these glove boxes labeled as $230-C-1$ and $230-C-2$ connecting to conveyor $\mathrm{HC}-3$. If these are the same glove boxes you are referring to, there are no known impacts. These proposed glove boxes are part of the security upgrade designs currently underway. I must say again that any room configuration or calciner location different than that originally proposed will necessitate another risk analysis and may result in significant security design changes.

Paul Klear

Forward Subject: Glove

Box $\mathrm{HC}-7$ and $\mathrm{HC}-15$

Author: Paul F Klear at NHC246

Date: $11 / 17 / 95$ 3:29 PH

If the HC-7 or HC-15 glove box is used for the ealciner, a new Vulnerability Analysis (VA) would need to be done. The security upgrades required as a result of the VA would result in additional motion detection coverage of the new target areas. The conveyor belt hoods in these areas may also need additional barriers. The cost of the analysis and resuiting security upgrades would be significant but cannot be determined until the new VA is complete. The security upgrade designs are well underway in a number of areas, so the sooner we can lock down the process configuration the less rework to the existing security designs will be required.

Paul Klear

$372-3448$ 
WHC-SD-CP-FDC-003, Rev 0

Page $A-30$ of $A-32$.

LOCATION ASSESSHENT OF VERTICAL CALCINER

$R \in f$ HHC-SO-CP-TI-200

REV. O PAGE 28

APPENOIX D - IKSTALLATION COST ASSESSHENT

(See following Pages for Estimate Sumary) 
LOCATION ASSESSMENT OF VERTICAL CALCINER

APPENDIX D - INSTALLATION COST ESTIMATE

\section{(CONTINUED)}

- IEST . TRIERACBIVE ESTIHAIIHG

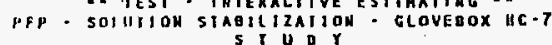

DOE_ROI. PROJECT COST SUHAARY
$R=P, W H C-S D-C P-T I-200$

REV. 0 PAGE 29

PAGE 1 OF a

DATE 12/08/95 13:13,00

ar T.L. HALD a.t. XOREIS

DOC 110 , $23005 A$ A

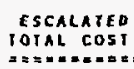

$x==x=0=0 \pm x$

EHGIHEERIHC

SPECIAL EOUIP/PRUCISS SYSIEHS

(ATJUSIED TO HIEI ,NOI 5100.4$)$

FOJECT TOTAL
150,000

400,000

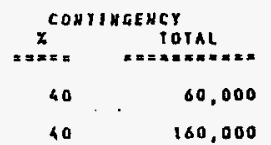

rotal.

DoLläs

$=\pi=0=0=3 \times$

210,000

560,000

\begin{tabular}{|c|c|}
\hline 550,000 & 40 \\
\hline
\end{tabular}

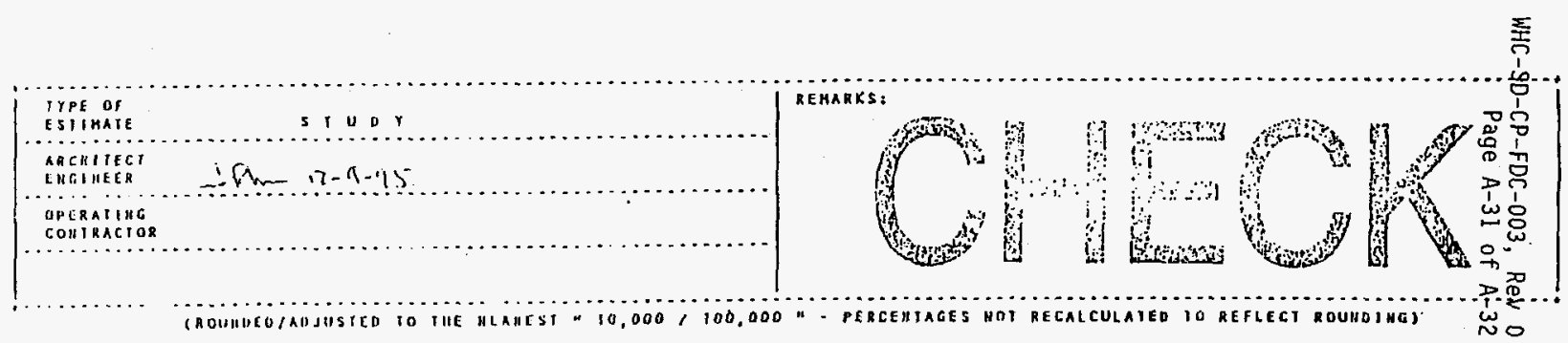


LOCATION ASSESSMENT OF VERTICAL CALCINER

APPENDIX D - INSTALLATION COST ESTIMATE (CONTINUED)

IAISER ENGINEERS HAKFORO

I.L. KOREIS

10B nO. 2JoOsab a ifst - interactive rstima:ing -

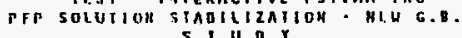

DOE_ROT. PROJECT COST SUMAAKY
Ref WHC-SD-CP-TI-200

REV. O PAGE 30

TAGE 1 OF

DATE 12100/95 13:26:56

OY I.L. NALOO

\section{$\cos t$} CODE

000

700

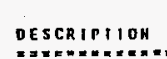

EHGJHEERIMG

SFECIAL EQUIRARRTESS SYSIEAS

(ADJUSIED TO HEET DOE 5100.4 )

PROJECI TOIAL

\begin{tabular}{|c|c|c|c|}
\hline ESCALATED & corr & SEENCY & TOIAL \\
\hline IOINi cosi & $\boldsymbol{\gamma}$ & IOIAL & OOLEARS \\
\hline$E===-==m=\mathrm{z}$ & $=x x=2$ & $5 x x=2 x=E x=$ & $=x=\leq x * 2=\pi$ \\
\hline 50.000 & 40 & 20,000 & 70.000 \\
\hline $14,0,000$ & 100 & 60,000 & 200.000 \\
\hline
\end{tabular}

140,000

60,000

200.000
190,000
40
00,000
270,000 
WHC-SD-CP-FDC-003, Rev 0

Page B-1 of B-47

APPENDIX B 
Sta 5 ENGINEERING DATA TRANSMITTAL

2. To: (Recoiving Orpanization)

Utoniun Process Support

Laboratory

5. Proj./Prog-/Dept.Jiv.: PFP/ENG/TRP

8. Oripinetor Remarks:

WHC-SD-CP-FDC-003, Rev 0

3. From: Page $B-2$ of $B-47$

PFP Design Engineering

6. Cog. Engr.: F. D. Fisher
IAN29 1996

Ref No 700526

i. $\mathrm{EOT}_{4 . \mathrm{N}}$

$N / A$

7. Purchass Order No.:

$N / A$

9. Equip./Component No.:

$\mathrm{N} / \mathrm{A}$

10. Syctem/Eldg./Facility:

234-5Z/PEP

12. Nisjor Assm. Dwg. No.:

SKX-2-300303

i1. Recelver Remarks:

13. Permit/Petmit Appliestion No.: $N / A$

14. Requited Responso Doie: $N / A$

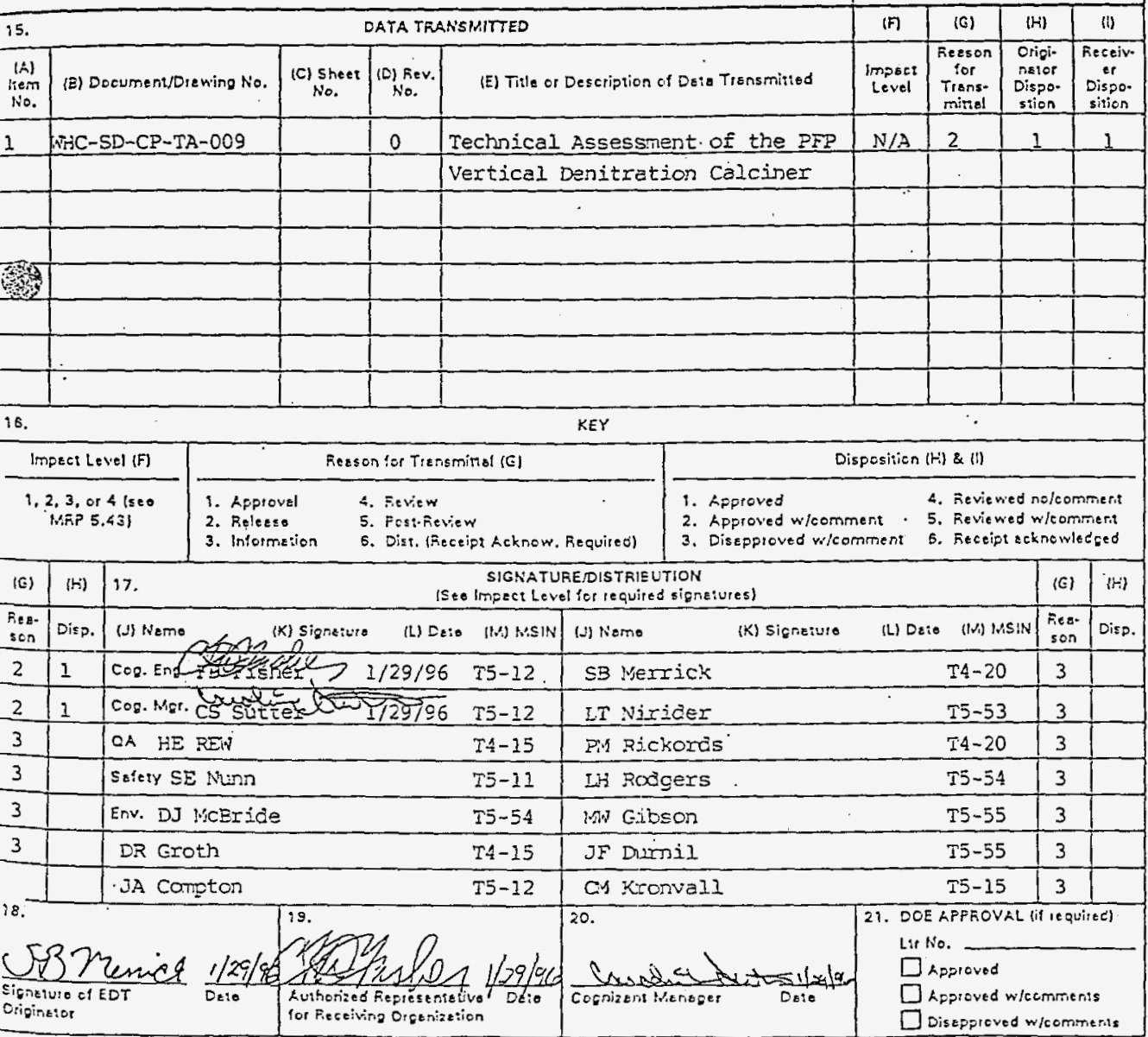


WHC-SD-CP-FDC-003, Rev 0 HHC-SD-CP-TA-009, Rev. 0

Page $B-3$ of $B-47$

\section{TECHNICAL ASSESSMENT OF THE PFP VERTICAL DIRECT DENITRATION CALCINER}

\section{SB Merrick, and PH Rickords}

Westinghouse Hanford Company, Richland, WA 99352

U.S. Department of Energy Contract DE-ACO6-87RL10930
EDT/ECN: 700526
UC: $\quad$ UC -721
Org Code: 15520
Charge Code: $K 6136$
B\&R Code: EW7003000
Total Pages: 45

Key Words: Calciner, material stabilization, liquid scrap stabilization

Abstract: This peper documents the development, fabrication and testing of the prototype PFP vertical direct denitration calciner. This calciner is designed to treat plutonium nitrate solutions at temperatures of up to $1000^{\circ} \mathrm{C}$ and directiy render them into a stable, storable solid oxide powder. The prototype vertical calciner succeeded in meeting all of its design objectives. With a few minor operability enhancements, the vertical direct denitration calciner should prove to be a valuable tool for stabilization liquid plutonium scrap material.

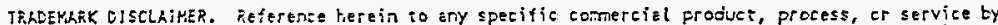
trede neme, iredemerk, renufacturer, or ciherwise, does net necesserily constituie or imply its ensorsement, recomendation, or fivoring by the United states evernment or any ageney therecf or its comreciors or subeoniraciers.

Frinted in the United stetes of hrierica. To obtain copies of this document, contact: hric/scs

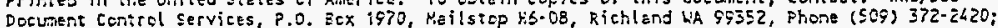
FEx (505) $376-4589$.
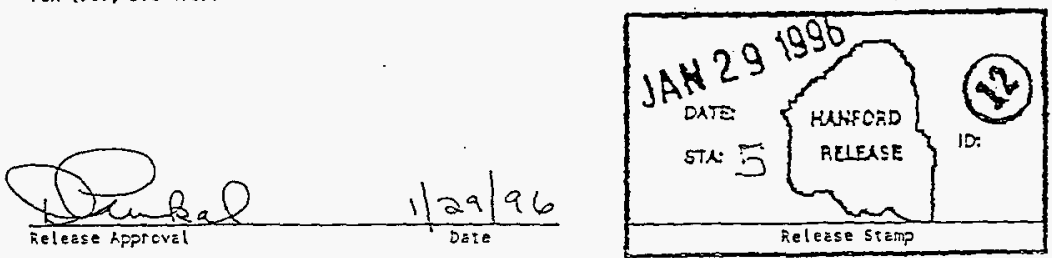

Approved for Public Release 
WHC-SD-CP-FDC-003, Rev 0

Page $B-4$ of $B-47$
Ref. $H H C-S D-C P-T A-D O Q 9$

Revision 0

Page 2 of 45

\section{TABLE OF CONTENTS}

1.0 PFP VERTICAL OENITRATION CALCINER TECHNICAL ASSESSMENT . . . . 4

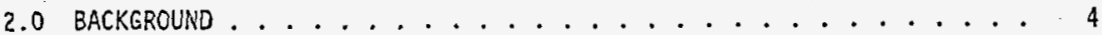

3.0 PROTOTYPE CALCINER TEST EXPERIENCE . . . . . . . . . 7

4.0 PROCESS DESCRIPTION ................... 8

5.0 VERTICAL DIRECT DENITRATION CALCINER ............. 10

5.1 Calciner Shaft Bushings and Seais ........... 12

5.1 .1 Graphite Bushing Test Experience . ......... 13

5.1.2 Production-Scale Calciner Top Plate and Bushing Design Enhancements ............. 15

5.2 Agitator and shaft................... 15

5.2.1 Agitator Test Experience . . . . . . . . . . 17

5.2.2 Production-Scale Agitator Design Enhancements . . . . 17

5.3 Calciner Vessel Jacket . . . . . . . . . . . . 17

5.3.1 Calciner Vessel Wall Test Experience . . . . . . . 18

5.3.2 Production-Scale Calciner Vessel Design Enhancements

5.4. Calciner Base piate Assembiy . . . . . . . . 18

5.4 .1 overflow Dome and Heater Assembiy ...... 19

5.4.1.1 Overfiow Dome and Heater Test Experience... 21

5.4.1.2 Production-Scale Calciner Overflow Dome

Desion Enhancements ........... 21

5.4 .2 Material Feed Injector.............. 21

5.4.2.1 Material Feed Injector Test Experience.... 25

5.4.2.2 Production-Scale Calciner Feed System Design.

Improvements ............ 25

5.5 offgas filters. . . . . . . . . . . . . 26

5.5.1 Off́gas filter Test Experience ......... 28

5.5.2 Production-Scale Offgas Filter System Design Enhancements ............. 28

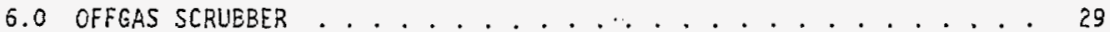

6.1 Offgas scrubber Test Experience ............... 31

6.2 Production-Scale Scrubber Design Enhancements ....... 31

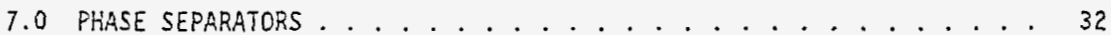

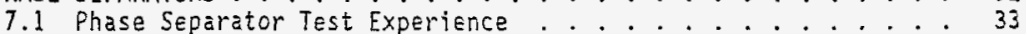

7.2 Phase Separator Design Enhancenents . . . . . . . 33

8.0 VACUUH TRAP . . . . . . . . . . . . . . . . 34

8.1 Potential Vacuum Trap Faijure liechanisms........ 34

8.2 Production Version Vaculm Trap Design Enhancements .... 34

9.0 VACUUH REGULATOR . . . . . . . . . . . . . . 35

9.1 Vacuum Reguiator Test Experierice . . . . . . . . 35

9.2 Recommended Vacuuri Regurator Design Enhancements ...... 35 
WHC-SD-CP-FDC-003, Rev 0

Page $B-5$ of $B-47$
Ref.WHC-5D-CP-TA-DO9

Revision 0

Page 3 of 45

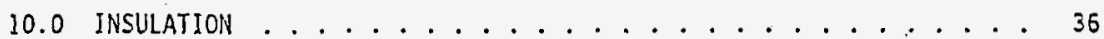

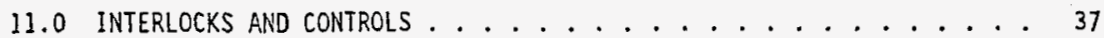

11.1 Calciner Temperature Controls . . . . . . . . . . . . . . . 37

11.2 Feed Solution and Caustic Makeup Flow Controls . . . . . . 39

11.3 Agitator Orive and Controls.............. . . 40

11.4 Glovebox High Temperature interlock........... 40

12.0 CONClusions ...................... 41

APPENDIX A SUMMARY OF CALCINER TEST EXPERIENCE . . . . . . . . . . . 42 
WHC-SD-CP-FDC-003, Rev 0

Page $B-6$ of $B-47$
Ref. WHC-SD-CP-TA-009

Revision 0

Page 4 of 45

\subsection{PFP VERTICAL DENITRATION CALCINER TECHNICAL ASSESSMENT}

In March 1995, the Department of Energy released its Plutonium Vuinerability lanagement $P 1$ an for the nation-wide DOE complex. This $p l a n$ included a requirement for PFP to stabilize the piutonium nitrate it held by January 1999.

PFP participated in the formutation of this report and its recommendations, one of which is to thermally stabilize the plutonium nitrate solutions at PFP. PFP initiated development of a vertical direct denitration calciner for these solutions in December of 1994 in anticipation of the 1995 plutonium vulnerability report release. PFP has completed development testing of the calciner on stand-in nitrate solutions, and has suecessfully performed testing on some plutonium nitrate solutions.

The traditional prototype development process involves design and testing of a laboratory or pilot-scale unit. Data from this device is then used to scale up the process for production operation. A conscious decision was made to develop a prototype device that simulated the production-scale calciner to the greatest extent possible.

Documentation for the prototype was managed to the same rigorous standards as a final design. There is thus no doubt the test results directly apply to the production unit, and the core design documentation can be directly used for fabrication of the production-scale calciner.

This report provides a summary of test experience of the prototype vertical calciner, and it identifies modifications to improve operability and maintainability that will be included on the production-scale calciner.

\subsection{BACKGROUND}

Mechanically agitated caiciners have been useful for many years in the DOE complex to thermally treat nuclear materials. These calciners have typically been designed to operate at lover temperatures than proposed for the PFP vertical direct denitration calciner. Their primary function was to produce reactive oxide materials as a step in the production of nuclear weapons. Typical challenges with earlier horizontal calciner designs included 
WHC-SD-CP-FDC-003, Rev 0

Page $B-7$ of $B-47$
Ref. WHC-SD-CP-TA-009

Revision 0

Page 5 of 45

bearing and seal failure through direct exposure of these components to the abrasive oxide powder, and the inability to provide bearing lubrication at the elevated temperatures. A hard mastic-like material accumulated on relatively cool surfaces which sometimes caused the calciner to stall or completely seize.

The PFP vertical direct denitration calciner solves these problems through its unique design. The agitator bearing and shaft seals are completely outside and above the material chamber, and the feed solution is atomized and injected into a preheated bed of plutonium oxide starter material. As the solution contacts the hot, churning bed of material, it quickly decomposes, leaving behind residual oxide powder in the material bed. The gases and vapors are carried away under vacuum to the offgas treatment system. As the material accumulates above a certain level, it is skimmed off at an overflow port and collected as product.

A vertical calciner tested in 1962 was found not to be very suitable for nuclear weapons material production, as it tended to produce a largely nonreactive oxide material Even at relatively low temperatures. While the tendency of the vertical calciner to produce nonreactive oxide precludes its use in weapons material production, it makes it useful for stabilization of plutoniua nitrate solutions in preparation for dry storage.

The vertical calciner concept was successfully tested at low temperatures in 1962 as reported in document No. Hil -73765. The 1962 design operated at $300^{\circ} \mathrm{C}$. The new design has been enhanced to operate continuously at over $1000^{\circ} \mathrm{C}$. The higher temperature promotes rapid and complete decoriposition the plutonium nitrate solution to a stable, storable solid plutonium oxide powder.

The PFP vertical direct denitration calciner is a system consisting of the calciner itself, a one micron offgas filter bank, a feed storage vessel, metered feed pump, chiller, scrubber, neutralizer metering pump for the scrubber, collection vessels, vacuum trap, vacuum regulator, and an instrumentation and control system. A simplified flow diagram is provided in Figure 1. The characteristics of each major system compenent will be discussed in this report, including design challenges, test experience and future enhancements to be incorporated into the production calciner system equipment. 


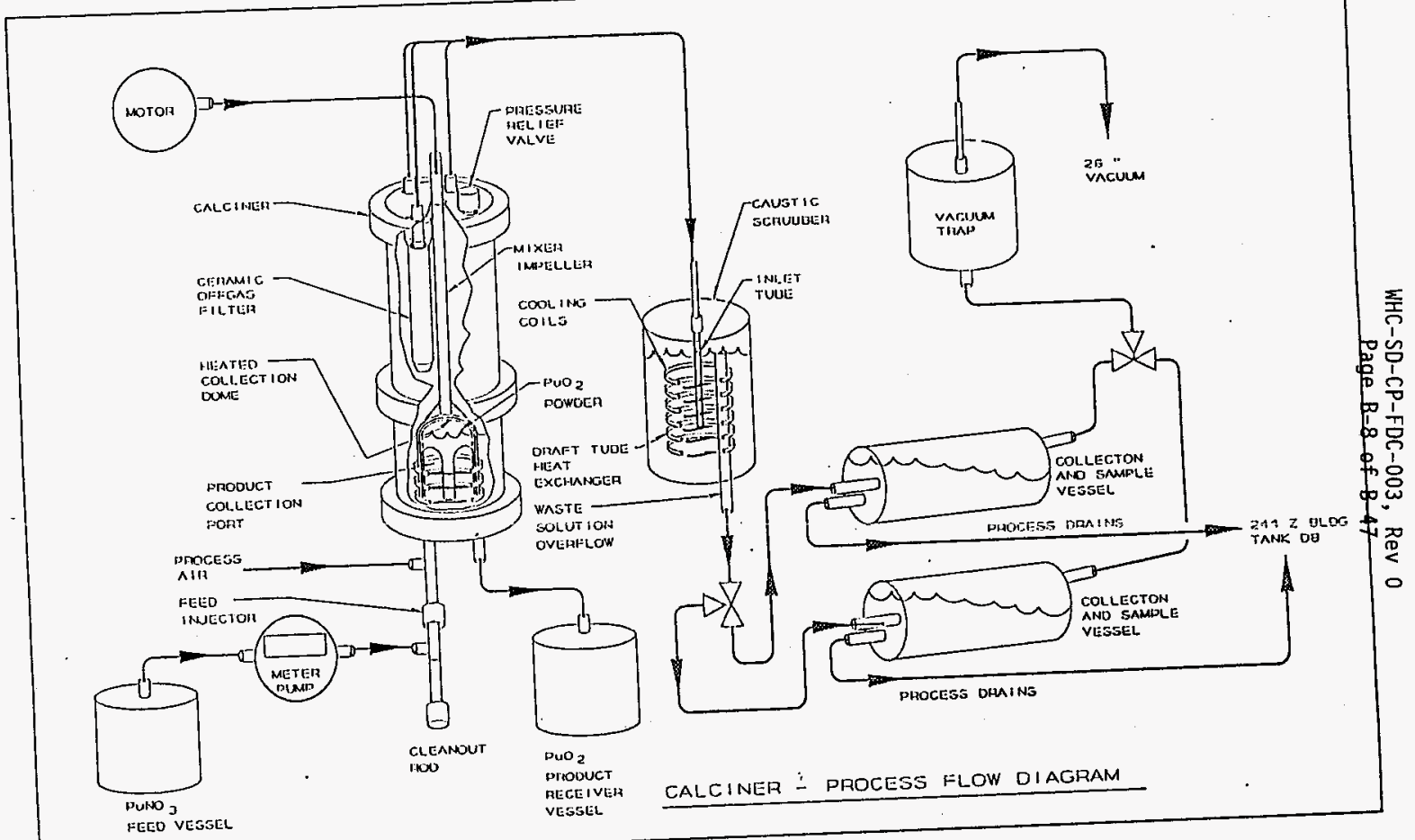

Figure 1 Simplificd flow diagram of the PFP vertical denitration calciner system. 
WHC-SD-CP-FDC-003, Rev 0

Page B-9 of $B-47$
Ref. WHC-SD-CP-TA-009

Revision 0

Page 7 of 45

\subsection{PROTOTYPE CALCINER TEST EXPERIENCE}

The PFP vertical direct denitration calciner has proven itself well under test conditions. Its feasibility has been demonstrated beyond our original expectations in testing so far. The calciner design was carefully engineered and thoroughly analyzed prior to fabrication and testing to ensure the greatest chance of successful testing. No major problems have been. encountered in the development process. A number of minor technical challenges were identified both prior to, and ouring testing, and successfully addressed by the technical and support staff. The flexibility of the design allowed improvements to be made and probiem areas corrected as they were identified.

To date, we have over 500 hours of total test experience with the prototype denitration calciner. This specifically includes 194 hours of development testing of the calciner materials and subassemblies; 34 total hours experience operating and testing of the controls and interlocks; 288 hours "dry" operational testing of the calciner system, and 20 hours of feed solution processing.

As each test was performed, any required design improvements identified Were processed and incorporated prior to continuing development testing. The calciner and its support equipment consequently evolved with each test cycle, improving in performance and reliability with each test run. Test experience and related actions taken are summerized in Appendix $A$.

Test runs are continuing to provide process chemistry related information. These tests will help determine if the concept of direct thermal denitration and stabilization of plutonium nitrate solutions should be carried forward in a production process. 
WHC-SD-CP-FDC-003, Rev 0

Page $B-10$ of $B-47$
RefWHiC-SD-CP-TA-OOS

Revision 0

Page 8 of 45

\subsection{PROCESS DESCRIPTION}

This calciner is used to convert plutonium nitrate solution into a stable, storable plutonium dioxide powder. The conversion is accomplished by heating to (2) boil off the liquids, (2) decompose the nitrate anion, leaving only an oxide compound, and (3) improve the properties of the oxide crystals as they reach appropriately high temperatures. This calciner uses the direct denitration process to avoid introducing additional chemicals into the calciner.

Plutonium nitrate feed solutions from various sources are injected with a controlled flow of air into the bottom of the caiciner at a controlled rate. The calciner contains a pre-mede bed of plutonium dioxide powder that has been heated to $1000^{\circ} \mathrm{C}$ while being agitated. A thin layer of the nitrate solution is sprayed onto the hot, moving particies of oxide. This layer quickly dries due to the high starting temperature and the close proximity of the heated calciner walls. The resulting layer of crystalline plutonium nitrate decomposes to oxide and $\mathrm{NO}_{x}$. The newly formed oxide increases the particle size and, eventually, the bed volume. The particles are moved around the annular section of the calciner by the agitator, which allows them (1) to receive new feed spray from the feed puim and repeat the growth, and (2) to be heated to ever higher temperatures as the larger particles work their way upward in the bed. Eventually, the particies reach the top of the bed and fall into a tube leading to the product collector. The product collection vessel is glass, and is manually removed and emptied into cans, as needed.

The water vapor, nitric acid vapor, decomposition gases, and atomizing air flow upward through the bed and out the top of the calciner. These gases pass through sintered ceramic filter elements to remove any entrained plutonium dioxide powder. They are then ore transported by vacuum into a chilled scrubber. The scrubber cools the gases to condense most of the water vapor and intact nitric acid vapors. The scrubber uses a recirculating caustic solution to react with the decomposition gases, reducing most of them to soluble salts. Caustic solution is metered continuously into the scrubber to maintain the desired caustic concentration. 
The scrubber is designed with an internal chimney-shaped "draft tube" to induce a recirculation pattern as the gases pass through. A liquid/gas mixture flows upward through the inside of the draft tube and downward on the outside with some of the gas bubbles still entrained. The draft tube is made from a single tightiy coiled tube that contains cooling water inside. The tight coiling minimizes the amount of scrub solution passing directly from the inside to the outside of the draft tube, which would decrease the recirculation effect. It also increases the surface area of the heat-exchanger coils. Gases not entrained by the scrub solution exit the liquid at an open area in the top of the scrubber, then pass out of the scrubber through an overflow tube along with part of the reacted scrub solution.

This gas/liquid mixture flows into one of two tanks where the phases separate. When one tank is filled with liquid, its contents are sempled and analyzed to ensure that the solution is acceptable for entry into the building drain system; mearwhile, the second tank is filling.

The gases exit continuousiy from the top of the tank and pass through a dedicated vacuum trap. This trap is designed to (1) ensure separation of the liquid and gas phases, and (2) prevent overflowing liquid from passing through the trap into the building vacuum system. The second objective is accomplished by the presence of a float that will seal the exhaust side of the vacuum trap if enough liquid enters. This sealing action el iminates the vacuum in the offgas piping, which ends the flow of gases through the system. The liquid level in the scrubber orops as the remaining gases separate due to lack of circulation, thus ending the overflow of liquid from the scrubber. Gases building up inside the calciner are exhausted through a pressure relief device at the top. 
WHC-SD-CP-FDC-003, Rev 0

Page $B-12$ of $B-47$
Ref. WHC-SD-CP-TA-009

Revision 0

Page 10 of 45

\subsection{VERTICAL DIRECT DENITRATION CALCINER}

The design of the test scale calciner presented many challenges to meet the design requirements. The operating temperatures and related corrosion issues presented serious materials challenges and limited the types of materials that could be used.

The calciner needed to be able to resist corrosion from nitric acid, and possibly trace amounts of hydrochloric acid and hydrofluoric acid in some feeds. It is designed to maintain a solution feed rate of 4 liters per hour, and it must sustain material bed temperatures of around $1000^{\circ} \mathrm{C}$. The calciner is engineered to be inherently critically favorable under any conditions. It is engineered to generate minimal waste, both in hazard and quantity.

A principal advantage of the vertical calciner design is its flexibility. Its modular design allows any of its subcomponents to be raadily replaced. This enables repairs, upgrades or modifications to be made with minimal difficutty.

The main components of the calciner are fabricated from type 310 stainless steel. This material was chosen for its strength, thermal conductivity, and resistance to corrosion and thermal stress cracking for the majority of the known conditions that would be present inside the calcirier, and for its ability to perform these functions at very high temperatures. All welding was done using type 310 stainless filler metal as well.

Figure 2 shows a cross-sectional view of the prototype vertical direct denitration calciner and identifies all of its major subcomponents. Each of these components will be discussed in the following sections. 
WHC-SD-CP-FDC-003, Rev 0

Page $B-13$ of $B-47$
Ref. WHC-SD-CP-TA-009

Revision 0

Page 11 of 45

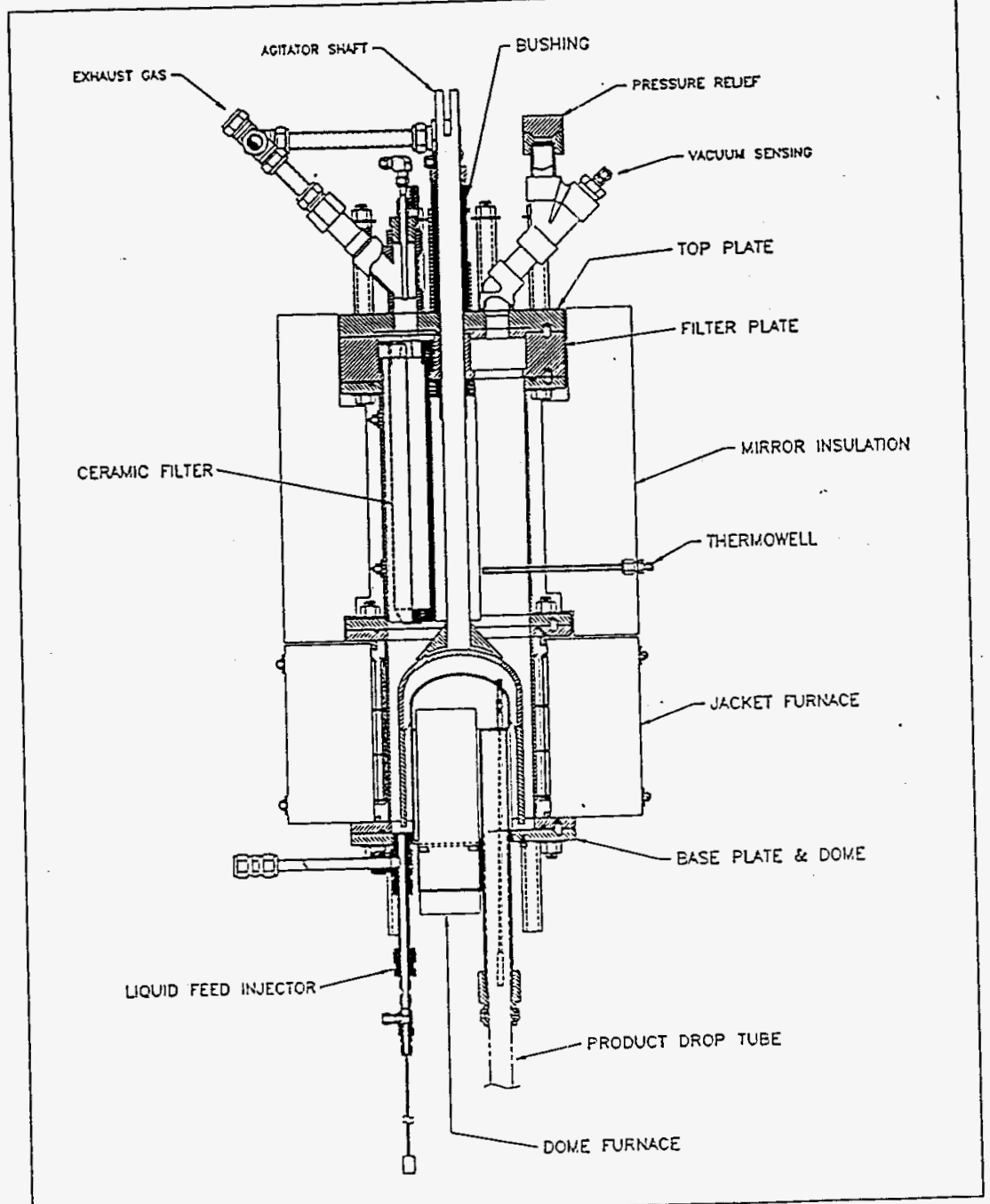

Figure 2 Cross-sectional diagrem of the PFP vertical denitration calciner. 
WHC-SD-CP-FDC-003, ReV 0

Page B-14 of B-47
Ref. WHC-SD-CP-TA-OOg

Revision 0

Page 12 of 45

\subsection{Calciner Shaft Bushings and Seals}

On top of the calciner there is a 1 inch thick plate with fittings welded to it to direct the offgas to the scrubber, a hole for the shaft, a: pressure release, and a sleeve to hold the shaft alignment bushing in place. The top plate also provides the seal pressure for the filters and shaft packing.

The bushing alignment sleeve is welded to the calciner top plate, and is one of the key areas in the calciner design. The primary function of the top bushing and sleeve is to align and center the agitator shaft within its bore hole in the top and filter plates. This bushing was also designed to support the weight of the agitator and shaft, serve as a gas seal to preserve vacuum in the calciner vessel, and act as a thrust bearing.

The alignment bushing and sleeve assembly sustains by far the largest mechanical stresses in the calciner. Lateral forces on the 2 foot agitator are opposed largely in the 4 inch long bushing sleeve and the single weld at the base of the sleeve.

Proper alignment of the top plates and filter plates is crucial to allow the guide bushing to ensure the shaft makes no contact with the plates. Improper alignment has twice caused the agitator to stall during testing; once through galling of the shaft on one of the plates, and once by binding of the bushing and shaft.

It was found that the alignient difficulty arises from intentionally loosely toleranced aligment pins (it was feared that press-fit tolerance of the stainless steel alignment pins might cause them to seize the plates together at high temperatures), and from the ability of the top plate to rock sightiy on the offgas filter washers. Both of these areas will be improved in the production calciner.

A second shaft bearing is located inside the calciner vessel inset into the lower portion of the filter plate. This bearing heips distribute the forces exerted by the agitator shaft over a wider area, and assists in aligning the shaft to prevent the shaft contacting the steel of the filter plate. The internal shaft bearing is subject to an extremely harsh environ- 
WHC-SD-CP-FDC-003, Rev 0

Page $B-15$ of $B-47$
Ref. KHC-SD-CP-TA-DOg

Revision 0

Page 13 of 45

ment. It is directly exposed to the intense temperatures, abrasive dust, and corrosive atmosphere within the calciner vessel.

An extensive industry search for suitabie bushing material was conducted early in the design process. Bearing experts, ceramics experts, and other calciner design experts were consulted to find bushing material capabie of withstanding temperatures up to $1200^{\circ} \mathrm{C}$, abrasion, and the corrosive atmosphere within the calciner. Silicon carbide was initially selected for the bushings due to its corrosion resistance and excellent ferformance at high temperatures. These were soon replaced with graphite, as discussed below.

In addition to providing shaft alignment, the upper bushing was designed to serve as a vacuum seal. The engineered tolerance permits some air to be pulled downward between the shaft and bushing. This was designed to provide some cooling to the shaft and to clear any product dust that might accumulate between moving surfaces causing abrasion and hear.

\subsubsection{Graphite Bushing Test Experience}

The silicon carbide shaft alignment bushing fractured during the first test run of the calciner. The fracture was caused by too tight of tolerance between the agitator shaft and the bushing. It was not known at the time of initial design what the differential thermal expansion rates were between the ceramic bushing and the stainless steel. The riaterial data sheet for steels or any other metal do not extend up to the nominal operating temperature of our calciner, and that information was not available from the manufacturers.

Calculations based on expansion rates extrapolated from the data sheets underestimated expansion of the steel shaft. Consequentiy, the shaft overexpended within the bushing, causing the bushing to fracture. The tolerances were appropriately redesigned, the bushing material was changed to graphite, and no problems with bushing breakage have since been encountered.

In early development testing, the high compressive stresses at the edges of the bushings caused chipping of the flat ceramic surfaces. The small silicon carbide flakes chipped from the bushing caused excessive friction and rapid wear of the agitator shaft. It was also conceived that if the carbide 
internal bearing were to fracture, it could fall down into the material bed and cause potentially serious damage to the agitator or the calciner vessel. It was quickly determined silicon carbide bushings in this configuration were not well suited for this application.

Fortunately, the testing revealed the heat of the agitator shaft above the calciner top plate to be less than $300^{\circ} \mathrm{C}$, significantly less than the worst case temperature enticipated. Internal temperatures at the top of the filter section were found to be about $700^{\circ} \mathrm{C}$ or less. This finding enabled the replacement of the carbide bushings with high temperature nuclear grade graphite. These have worked very well, so far. As these graphite shaft alignment bushings gradually wear from friction with the shaft, the eroded powder serves to provide further lubrication to wear surfaces below.

During early testing using a very fine magnesium oxide stand-in material, pressure pulses from the filter blow-back system during full flow operation caused brief periodic pressure reversals, puffing dust up between the bushing and shaft. This would not have been likely when processing higher density materials such as plutonium oxide. It was nevertheless determined that the design should be changed to seal this area. Fortunately, the lower than expected temperatures in this region allowed the installation of an airtight graphite and fabric shaft seal in the filter plate. This seal has worked well in continued testing.

The wear rate of the graphite bushings from friction with the agitator shaft has been found to be minor. After more than 80 hours of agitator operation, the only significant wear observed resulted from a misaligned shaft. No significant wear of the shaft alignment bushing has been observed when the shaft is properly aligned.

In the original design phase, temperatures up to $1000^{\circ} \mathrm{C}$ on top of the calciner were conservatively anticipated. Consequently, the locator pins that were put in the top plates had large clearances to prevent oxidation problemis and/or an interference fit. Due to this clearance, it has been difficult to align the plates to the shaft inside the glovebox.

Alignment of the top and filter plates in the prototype calciner is largely accomplished through the skill of the craftsmen performing the 
WHC-SD-CP-FDC-003, Rev 0

Page $B-17$ of $B-47$
Ref.WHC-SD-CP-TA-009

Revision 0

Page 15 of 45

assembly. Misalignment of the top plate and filter plate will subject the bushing to increased stresses. Interference between the shaft and the filter plate shaft bore from the misalignment resulted in excessive friction which caused the agitator to stall during two of our test runs. Should we have any further alignment difficulties, a mating ring has been designed which can be placed between the calciner plates to-prevent rocking of the top plate on the filter washers and will ensure that the top and filter piates remain parallel. 5.1.2 Production-Scale Calciner Top Plate and Bushing Design Enhancements

Reliability of the graphite bushing will be further enhanced in the production version by increasing the iength of the bushing to reduce the surface pressures exerted from shaft moments. To ensure proper vertical and horizontal alignment of the shaft with the plate bore, alignment pin and plate tolerances will be tightened, and diamond locator pins will be provided to ensure positive plate alignment. The calciner top plate will also be machined to fit completely over the filter seal washers. It will be engineered to provide the required pressure on the flexitallicos seal washers while mating flush with the filter plate.

\subsection{Agitator and Shaft}

The agitator was designed to provide a continual mixing action of the material bed and to serve as an impeller to orive processed powder to the product collection port. It rotates at a nominal $60 \mathrm{rpm}$, adjustable between 0 and $120 \mathrm{rpm}$. The action of the agitator causes the material to wipe against the vessel walls and absorb heat from the inner (dome) and outer (jacket) heating elements. Heat is transferred from the oxide bed to the material which has been fed into the chamber from the injector port.

The agitator and shaft are shown in Figure 3. The agitator was engineered in a domed shape. The domed shape serves as a heat shie?d, concentrating the intense temperatures in the reaction bed. This greatly enhances the efficiency of operation, while sheltering the upper section of the calciner from the temperature extremes in the calciner reaction bed. The arched shape

1) Flexitallic is a tredenark of flexitallic tasket company, inc., Defr park, tX 
of the agitator blades also serves to provide reinforcement to the softened steel in the presence of relatively large forces on the blades.

The agitator shaft was made from l inch diameter 310 stainless steel shafting material. The agitator was fabricated from a 5 inch pipe cap and 1/4 inch plate and welded onto the shaft. A conical cap was placed on top of the dome to reinforce the shaft-agitator joint. More importantly, the conical cap helps shed the heavy oxide powder from the top of the agitator to minimize load on the thrust bearing. It also helps prevent powder buildup from accumulating to the point where it interferes with operation of the filters.

The agitator blades are continuously rotated through the oxide bed. Plutonium oxide is extremely abrasive and, over time, will erode away the blades of the agitator. The agitator has been designed to be replaceable under routine maintenance, although it is important to minimize required main-

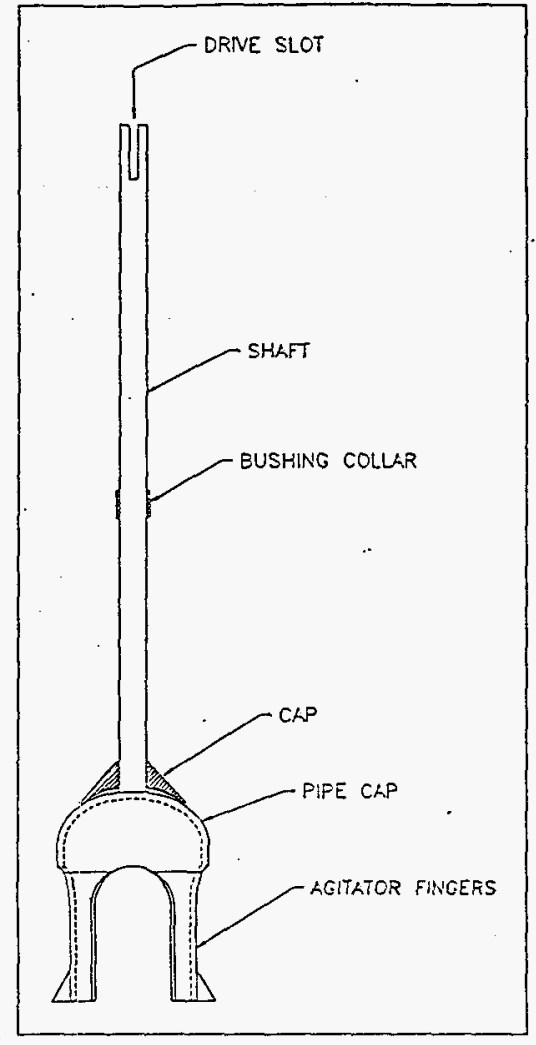

Figure 3 Calciner agitator/impeller and drive shaft. tenance intervals. The blades are therefore designed roughiy an inch longer than necessary for clearance with the overflow dome. This is intended to allow the agitator to be adjusted downard as the ends of the blades erode from contact with the abrasive material bed. 


\subsubsection{Agitator Test Experience}

During early testing, it was determined that the agitator blades needed to be twisted to provide sufficient mixing of the bed material in the calciner. The added resistance of the modified agitator necessitated use of a larger motor to turn the shaft. The agitator motor horsepower was increased to $1 / 4 \mathrm{hp}$ from the $1 / 12 \mathrm{hp}$ motor originally specified. The new motor is. torque limited to 50 inch-pounds to prevent damage to the agitator or vessel should the assembly stall.

The wear rate of the agitator has been insignificant. After over 80 hours agitator run time in the oxide material ted, we have not yet observed significant wear on the all steel agitator.

\subsubsection{Production-Scale Agitator Design Enhancements}

Although the agitator is designed to be easily replaceable as it wears, its test performance has exceeded our expectations. No changes to the agitator are planned for the production calciner.

\subsection{Calciner Vessel Jacket}

The calciner jacket provides the basic structure of the calciner. It conducts heat from the furnace, or jacket heater, to the material in the reaction bed. For criticality safety, it is limited in diameter to 6 inches nominal; and in height to the minimus necessary to contain the filters, agitator, and overflow housing.

The calciner vessel is constructed of high temperature, low carbon 310 stainless steel. An extensive number of other materials were investigated for construction of the calciner vessel. These included various steel alloys, Hastelloys, Inconels, various refractory metals, and ceramics. The other materials were ruled out for a variety of reasons, including low melting or annealing point; poor corrosion resistance to nitrate, chlorides or fluorides; low availability; or problems with brittieness or potential thermal stress cracking. One of the chief difficulties in material selection was that very few of the material properties charts extend up into these extreme temperature ranges. Even with the high temperature 310 stainless steel, the calciner 
operates near the absolute limits of the material capabilities $\left(1100^{\circ} \mathrm{C}\right.$ maximum operating, temperature, corrosives, abrasives, etc..).

The outer shell of the calciner was fabricated in two sections. This was done to facilitate maintenance and to provide both a thermal barier and thermal stress relief between the hot lower reaction section and the cooler upper filter section of the calciner. The two calciner sections were fabricated using 6 inch schedule 10 pipe, and flanges of $1 / 2$ inch plate. The flanges were machined to square off the faces and form the grooves for the $0-$ ring seals.

A thermowell was installed in the upper section using $1 / 4$ inch 310 stainless tubing to allow measurement of temperatures in the filter section of the caiciner vessel.

Only minor aging of the calciner vessel is expected over the duration of any anticipated process campaign. Eventually the calciner vessel will wear out by one of several mechenisms, including corrosion, abrasion, high temperature oxidation or scaling, or thermal stress cracking. This is considered normal wear. The age-related failure in any of these areas will be manifested by a steady increase in difficulty maintaining vacuum within the vessel. The modular design of the calciner has been provided to allow replacement of worn out components.

\subsubsection{Calciner Vessel Wall Test Experience}

The 310 stainless steel has so far proven adequate under test conditions. With over 200 hours of high temperature testing done to date, the outside walls of the lower part of the calciner vessel around the furnace have only lightly oxidized. There is only slight dulling of the stainless steel shine on the inside of the calciner. No scaling is evident either inside or outside the calciner as would be expected with type 304 stainless steel after exposure to these temperatures. All of the flange weld joints have remained in excellent condition.

\subsubsection{Production-Scale Calciner Vessel Design Enhancements}

No significant chenges are plenned to the production calciner vessel. The 310 stainless steel has held up well in testing. It is not anticipated 
that vessel life can be significantly enhanced through use of Hastellioy, Inconel, or other grade of stainless steel. For the current stabilization program, the 310 stainless steel selected is fully expected to perform satisfactorily.

\subsection{Calciner Base Plate Assembly}

The calciner baseplate is a machined weldment that includes the overflow dome and heater assembly, the feed injector assembly, and several thermowells for temperature measurement. Figure 3 is a diagram of the baseplate assembiy. These subcomponents are discussed below.

\subsubsection{Overflow Dome and}

Heater Assembly

The overflow dome and heater assembly provides several key functions in the calciner operation. It houses one of the two calciner heat sources, an 1100 Watt, $1400^{\circ} \mathrm{C}$ Kanthal cenister heater. Radiant heat is transferred from the heating element to the overflow dome. From the dome, heat. is transferred primarily by direct conduction to the material bed. The dome also houses the product collection port, or "overflow tube." This is a one inch tube inset into the dome

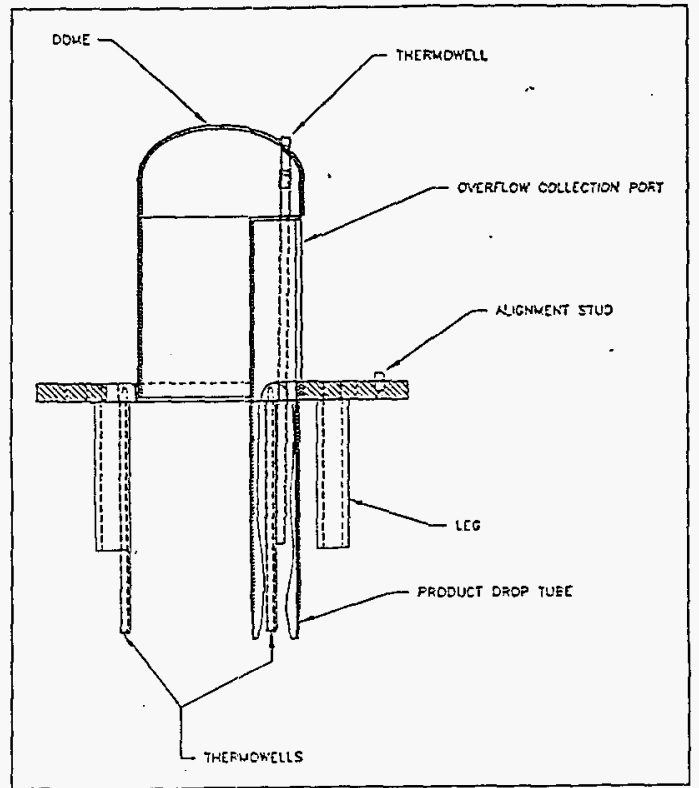

Figure 4 Cross-sectional diagram of the calciner baseplate assembly. wall. The overflow tube is adjusted vertically to set the depth of the 
material bed. Finally, the dome assembly serves to contain the material bed in the area of the agitator blades to promote rapid mixing and heat transfer.

The main body of the dome was fabricated from 4 inch stainless pipe and pipe cap. The dome was seal welded to the bottom edge of the bottom plate, and a cosmetic weld was placed between the dome and the top surface of the lower plate. A slot cut out on one side of the pipe accommodates the overflow tube which permits the excess bed material to drop into a collection vessel.

The 1100 litt dome heater was mounted inside the dome and anchored to a mounting bracket attached to the lower plate. A thermowell was attached to obtain temperature readings from the top surface of the dome, one of the hottest surfaces on the calciner.

The collection tube extends down well below the base of the calciner. It is adjustable vertically via a Teflon ${ }^{e 2}$ fitting and calibrated to allow the depth of the material bed to be adjusted externally during calciner operation. The base of the collection tube is connected to a ball valve mounted on the top plate of the product receiver vessel. This valve allows material collection to be suspended without interrupting operation to allow the receiver canister to be replaced.

The overflow dome will age due to the same mechanisms as the vessel wall discussed under Section 5.3. Corrosion, oxidation, abrasive erosion, and stress cracking can be expected after extended operation.

The heated surface of the dome is maintained at over $1000^{\circ} \mathrm{C}$ during operation. Less than 2 centimeters away, the feed port is injecting room temperature air and feed solution. The resultant thermal gradient causes very high stress on the materials and the intervening weld. This may eventualy lead to stress cracking at this point. cracking of this weld is not considered significant, as it is primarily cosmetic. The primary dome seal weld is located at the bottom of the base plate, outside the area of significant thermal stress.

2 ieflon is a tradenatk of E. 1. DuFont de kemours \& Co., hilmington, DE 
WHC-SD-CP-FDC-003, ReV 0

Page B-23 of B-47

RE, HHC-SD-CP-TA-0O9

Revision 0

Page 21 of 45

Should the base plate assembly eventually wear out, it can be replaced with a spare unit. Without replacement of this component, age-related deterioration in the dome structure over extended operation could prevent adequate vacuum from being maintained, and would allow some material to escape and sprinkle down onto the drip pan beneath the product collection vessels when vacuum is interrupted.

\subsubsection{Orerflow Dome and Heater Test Experience}

As with the calciner vessel, only light oxidation of the overflow dome is evident after over 200 hours of high temperature testing. All weld joints have remained in excellent condition.

\subsubsection{Production-Scale Calciner Overflow Dome Design Enhancements}

The come assembly, as with other major components of the calciner, is designed to be replaceable should it eventually wear out. The life of the dome could be enhanced by elimination of the welded joints in the assembly. The dome housing could readily be cast and machined from 310 stainless, eliminating velded joints. This will only be considered if it is decided to operate the calciner considerably longer than is presently anticipated.

The base of the production scale calciner dome will be threaded into the calciner baseplate rather then welded, eliminating potential stress failure of the dome welds provided on the prototype calciner. For the projected operational period of the new production calciner, no other material fabrication changes will be made.

\subsubsection{Material Feed Injector}

The material feed port was surprisingly one of the more difficult design challenges faced by the calciner engineering design team. The challenge of providing a means of introducing cold liquid feed material into the calciner material bed reliabiy was significant. The feed solution must introduced into the calciner without wetting any of the calciner surfaces or boiling in the feed tube, and without it scaling and clogging the feed tube, saturating the top of the material bed, or interfering with the agitator operation. 
Fed from the top or side, the plutonium solution would have wet the top surface of the agitator. This would have eventually caused buildup of soidified paste to interfere with rotation of the calciner, and could have caused damage to the offgas filters. It would also have wet the top surface of the material bed such that incompletely reacted material could be carried out the overflow port to the collection vessel, reducing quality of the product. If introduced into the center of the materia? $b \in d$, the feed tube may have interfered with the free rotation of the agitator or prevented free circulation of the material in the bed. Introduced through the bot-

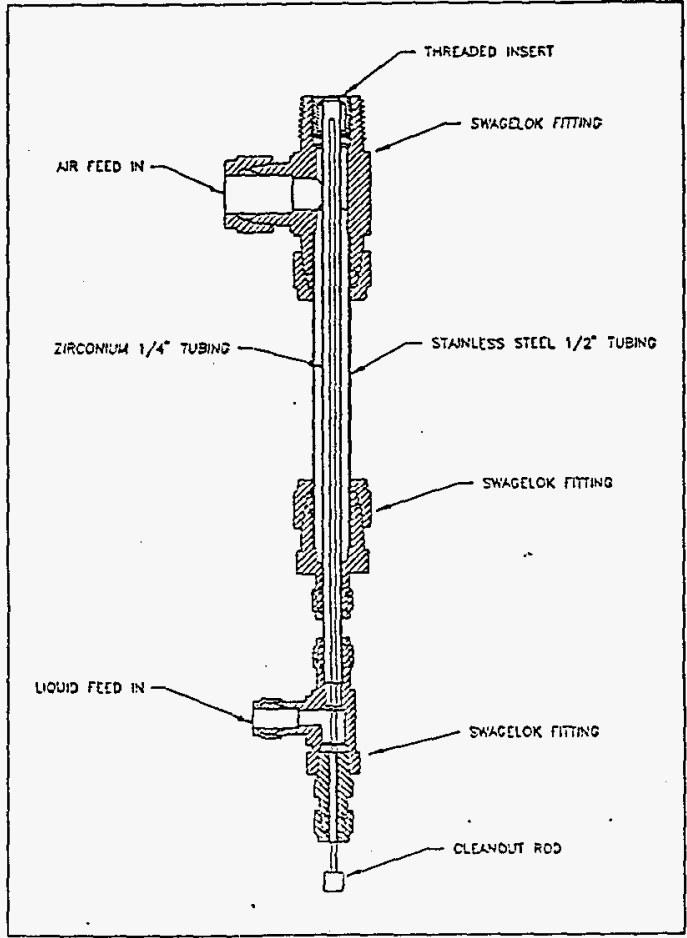

Figure 5 Calciner feed material injector assembly tom, the liquid must pass through a half inch thickness of the red-hot steel baseplate without boiling, and without severely cooling off the baseplate which would cause material stress and loss of calciner reaction efficiency. To prevent an unacceptably high corrosion rate, the feed material could not be allowed to boil off from the surface of the baseplate (or any other metal surface).

Ehegelok is a tredematk of crahferd fitting compasy, solon, on 
WHC-SD-CP-FDC-003, Rev 0

Page B-25 of B-47

Ref. WHC-SD-CP-TA-OOS

Revision 0

Page 23 of 45

After analyzing a number of potential feed tube design concepts, the best option was determined to be a bottom feed system where the solution is introduced through an injector system.

The injector is comprised of a liquid feed tube concentrically housed inside of an air line. The air serves to insulate liquid feed from the hot baseplate, as well. as to provide some cooling. This prevents the material from boiling inside the feed tube which would have led to excessive corrosion or possibly precipitative blockage of the feed tube. The feed line system is fitted with an air nozzle at the basepiate surface. The injection nozzle is engineered so that above 1 cubic foot per minute air delivery, the air velocity at the plate surface is supersonic. This breaks the feed liquid (fed at a maximum rate of about $1 \mathrm{~m} l / \mathrm{sec}$ ) into a fine mist, which is carried by the air up into the material bed. This prevents the feed solution from pooling and corroding the baseplate. Should the feed tube corrode or plug, it has been designed to be replaceable.

The feed port location has been engineered so the agitator blades wipe directly across the orifice roughiy 4 times per second. This is designed to continually bring new material in contact with the feed solution. It also helps prevent tube blockage, scale buildup, and pooling of solution.

During normal operation, fositive liquid feed flow prevents powder from the material bed from being packed down the tube by the action of the agitator. A cleanout rod has also been provided should the feed tube become plugged. It is designed to fit flush with the top of the baseplate and serve as a plug to prevent powder from being packed down the tube by action of the agitator when the feed pump is not running.

The feed tube is designed to be readily replaceable, although high temperatures in this area prevent safely doing so during operation. It is important to completely insert the cleanout rod at the completion of each run to prevent blockage. Periodic inspection of the feed tube should also be performed.

Loss of air pressure to the feed injector could cause corrosion and buildup of scale in and around the feed port. Lab tests with boiling acid revealed that the thickness of the 310 stainless liquid feed tube could 
corrode through at the liquid-vapor interface point in as few as 40 hours. operating personnel have been instructed to flush the feed tube after each run to help extend its life.

There was also a credible potential upon loss of air pressure for liquid to be forced by the feed pump back up the air line and into the process air system. For these reasons, an interlock was installed to shut down the feed pump should the air pressure fall below about to psi.

Should the air injector nozzle corrode or wear significantly over time, it will lose some of its effectiveness in dispersing the feed solution. It could also then be more likely to become blocked by the oxide product materia1. As the prototype calciner is designed for a limited operating life, the injector nozzle was not designed to be replaceable. For the production scale calciner, the entire feed tube and air injector assembly will be designed to be readily replaceable.

One possible operational hazard with the injector system is conceivable. The process air line supplying the-feed injector is known to have significant quantities of oil and water trapped in its piping. Should a large slug oi water or worse, oil, be injected through the feed injector air line into the hot caiciner vessel, the evoived gases would be emitted from the vent, potentially blowing quantities of the product powder into the glovebox. If oil is injected, it would be incompletely reacted and would likely be quite flammable as it is ejected from the vent.

It is clear that such an event could not be permitted. The air line was thus blown down when it was installed to remove as much liquid as possible, and filter traps were installed to separate any residual liquid. Nevertheless, during construction and prior to energizing the calciner, the airlines were pressurized for leak testing, the filter traps were overwhelmed, and water from the air line leaked into the glovebox from a loose fitting.

The hazard has been eliminated by modifying the filter trap drain lines such that they are left permenently open. Any liquid in the air line will now be trapped by the separators and diverted to a collection vessel. 


\subsubsection{Material Feed Injector Test Experience}

Experimental testing so far has shown that the feed injector design has worked extremely well. No evidence of surface corrosion or scale accumulation on the baseplate or within the feed system has been discovered. High quality, dry product is being delivered from the collection port.

The air injected into the vessel has been found to have the side benefit of keeping the temperatures in the upper section of the calciner lower than anticipated. This has permitted use of other desirable materials such as graphite for bushings in the construction of the calciner.

Prevention of blockage of the feed tube has been the greatest challenge faced with the feed system. During one test run, the cleanout rod was inadvertently left in its retracted position after completion of the run. The action of the agitator completely packed the feed tube with powder from the material bed. The powder mixed with the liquid in the feed tube and formed a paste. The paste baked into a hard, cement-like material during the extended c001 down cycle and the heat up cycle for the next test run and had to be replaced.

\subsubsection{Production-Scale Calciner Feed System Design Improvements}

The feed system on the production version of the calciner will be supplied from bottied gas. This will prevent any credible possibility of liquid entering the calciner through the air injector. The feed system will also be modified so that the entire injector assembly can be readily replaced as a unit. 


\subsection{Offgas Filters}

The calciner operates with a great deal of internal gas and vapor turbulence. Feed solution injected at $1 \mathrm{~m} \ell / \mathrm{sec}$ quickly vaporizes and decomposes into oxide powder, $\mathrm{NO}_{\mathrm{x}}$ and other gases. The injector air is introduced with the feed solution at about $2 \mathrm{scfm}$, but rapidiy expands as it is heated. These gases and vapors, combined totaling about $15 \mathrm{acfm}$, expand up through the hot material bed, lofting some powder from the material bed as they do.

The offgases must be removed from the calciner without allowing escape of solids. The offgases from the calciner are drawn off under vacuum through a set of 1 micron high temperature silicon carbide particle filteis. These filters ensure high efficiency of radionuclide separation from the waste gases, while minimizing contemination of the gaseous and liquid effluents.

The top section of the calciner is designed principally to house the offgas filters. The height of the filter section was determined by the length of filters required to handle full flow with 25 percent additional capacity. The three ceramic filters together have a capacity of about $20 \mathrm{cfm}$.

The filters are mounted in a 2 inch thick stainless plate machined to mate with the filter seals. Flexitallices gaskets on top of the filters are held in compression by the 1 inch top plate to provide a vacuum-tight seal. The top plate also houses the vacuum exhaust manifold, and the filter blowback assembly, as well as the agitator seal bushing sleeve, and the pressure release.

The offgas filters could conceivably break or become blocked. Breakage of the ceramic filters would prevent confinement of the oxide solids to the calciner vessel, and would allow particulates to be carried to the scrubber. Blockage would cause high differential pressure to overkhelm the available vacuum and restrict flow from the calciner. As positive pressure builds up above 2 psi, the pressure release weight would lift, allowing the offgases to escape into the glovebox.

3) Flexirellic is a tractierk ef flexitallie easket compinny, Ine., Deter park, TX 
The high temperature filters are made of silicon carbide ceramic. Significant mechanical or thermal shock can cause them to crack and lose their integrity. This is not considered likely. Once installed in the calciner, the filters are well shieided from mechanical shock. The calciner is also designed to eliminate the possibility of thermal shock caused by liquid spraying up and impacting on the filter candles.

The feed solution is slowly introduced by the feed injector into the calciner vessel under several inches of heated plutonium oxide as a fine atomized mist. Should the material bed be absent for whatever reason, the agitator covers the feed port and is designed to shield the filters from the feed spray. Mist impacting on the filters could not in any case induce sufficient thermal shock to cause filter damage.

With the high gas flow, moist air, and large ariounts of lofted powder, it was crucial to provide a means of clearing the filters while under operation. A filter blow-back system was thus engineered to accomplish this automatically.

The blow-back system sequentialiy sends a pulse of air to each filter. The pulse is directed through a venturi port, causing a small shock wave to dislodge any accumulated material from the filter surface.

Increasing the feed rate of the nitrate solution beyond the design limit of $4 \mathrm{l} / \mathrm{hr}$ might cause a vapor jet with enough velocity to break through the material bed and deposit moisture laden powder on the filter cartridges. This can quickly draw the temperature down, allowing the vapor to condense on the filters, compounding the problem. Should this happen, the high filter differential pressure indicator will light. If the feed rate is not reduced within a short time, steem will begin to vent through the pressure release. If the problem is corrected before a thick paste is formed on the filters, they should quickly dry out and allow the blow-back system to clear the blockage. Otherwise, the process will have to be shut down and the filters cleaned or replaced.

An excess of orgenics in the feed solution could also lead to filter blockage through coating the filters in an unreacted oily residue. By slowing the feed rate, the organics will be allowed to oxidize or evaporate, and the 
blow-back should clear the filters. This type of event is very unlikely, as the feed solution would have been carefully sampled for organics to prevent formation of organic nitrates.

\subsubsection{Offgas Filter Test Experience}

The filters have performed very well in testing. No deterioration of the filters whatsoever has been detected. Sampling found only very low levels of plutonium in the condensed calciner offgases.

Evidence from filter differential pressure measurements and post run inspection of the filter surfaces indicates that the blow-back system is performing effectively under operating conditions.

It is worth noting that in early testing with magnesium oxide stand-in material, the blow-back system could not keep up with the large volume of extremely fine lofted mag-ox powder. The magnesium oxide was replaced with more dense ceric oxide, which was more representative of plutonium oxide. The filters remained adequately clear once that substitution was made. It was thus determined that the filter and blow-back design was acceptable to allow initiation of process testing on plutonium nitrate. No blockage of the filters has been evident in testing with the plutonium solutions.

\subsubsection{Production-Scale Offgas Filter System Design Finhancements}

No modifications of the filter design is anticipated. 


\subsection{OFFGAS SCRUBBER}

The purpose of the scrubber is two-fold: (1) to cool and condense the vapors, and (2) to neutralize the acidic offgases with a caustic solution. Sodium hydroxide solution is currently used to neutralize these acids.

Figure 6 shows a diagram of the scrubber. The primary components of the scrubber are fabricated from quartz glass and stainless steel. The offgas from the calciner is brought to the scrubber under vacuum through an insulated $3 / 4$ inch stainless steel pipe. The offgases are brought into the scrubber through a $25 \mathrm{~mm}$ glass inlet tube and enter a $100 \mathrm{~mm}$ quartz gas dispersion chamber. At the top of the gas dispersion chamber is a fritted glass diffuse) disk designed to dispersa the offgases into smal1 bubbles. This facilitates efficient conduction of the heat from the offgases and neutralization of the acids.

The quartz glass resists corrosion initially expected from some of the test solutions, and it is able to withstand the temperature difference between the chilled caustic solution and stean and not crack.

The heat exchanger coils are tightiy stacked to provide a chimney effect. The bubbles, as they rise, create a current that circulates around the stainless cooling coils in the caustic solution. Once the bubbles reach the top, the gas, along with any excess liquid is pulled down the exhaust tube.

Al1 of these components are contained within two pieces of 6 inch diameter Pyrex ${ }^{e 4}$ glass pipe with stainiess steel top and bottom flanges and a stainiess steel service ring for chiller and caustic solution access. With the glass pipe, the fluid levels, color of the scrub liquor, and any other indications that there may be a problem can readily be observed.

4 Pyrex is a trademerk of Corning Glass torks, Corning, hy 
WHC-SD-CP-FDC-003, Rev 0

Page $B-32$ of $B-47$
Re WH'HC-SD-CP-TA-0O9 Revision 0

Page 30 of 45

$\therefore$

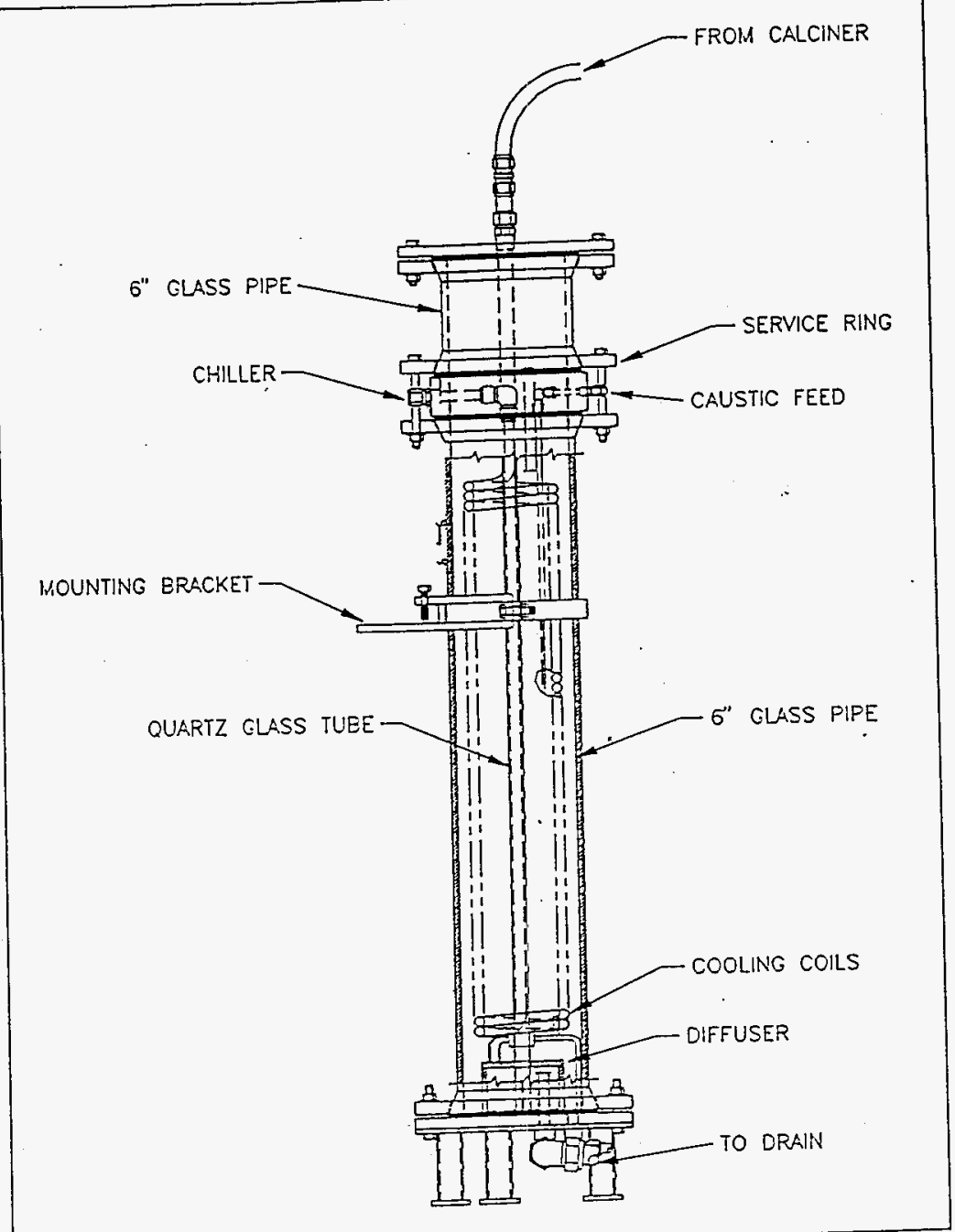

Figure 6 Diagran of the calciner off-gas scrubber. 


\subsection{Offgas Scrubber Test Experience}

The scrubber has performed very well in testing. Gases emitted from the scrubber have been free from acids, and have been consistently chilled below room temperature to condense excess vapor. Ho condensation has been evident in the glass vacuum trap vessel as the offgases are exhausted to the process vacuum.

The quartz glass tube was found to be too fragile for use in the production calciner system. The glass inlet tube fractured several times during assembiy. The design was modified, and there have been no further problems with breakage.

Glass welds have been identified as weak areas. In testing, the fritted glass diffuser disk and cylinder separated from one another at the weld. This was likely caused by the caustic solution exploiting flaws in the glass weld.

\subsection{Production-Scale Scrubber Design Enhancements}

Corrosion by chlorides and iluorides will be minimai due to their infrequent and dilute presence in feeds. Since the feed solutions will be characterized and treated for compatibility with the calciner, a stainiess steel inlet tube and a sintered stainiess dispersing filter will be employed for the production calciner.

The $\mathrm{pH}$ is controlled manually in the prototype scrubber by adjusting the caustic makeup pump flow rate to match the feed acidity, salt nitrate, and feed rate. In the production version, we will provide a pH analyzer/ controller. The controller will add just enough caustic solution to maintain the scrubber $\mathrm{pH}$ in the range of about 9 to 13. This will minimize corrosion of the vessels and tubing, and it will also minimize use of caustic neutralizer. 
WHC-SD-CP-FDC-003, Rev 0

Page $8-34$ of $B-47$
Ref. WHC-SD-CP-TA-OOg

Revision 0

Page 32 of 45

\subsection{FHASE SEPARATORS}

There are tho phase separators in the calciner system. These units separate the calciner offgases from the liquids which are comprised of the condensed vapor and the caustic make up solution injected into the scrubber.

The phase separators are each fabricated from a 4 foot piece of 6 inch Pyrex ${ }^{65}$ glass pipe, PVC end flanges, neoprene gaskets, and stainless steel fittings and tubing. Liquid and gases come from the scrubber to the separators through $3 / 4$ inch stainless stee] tubing and valves.

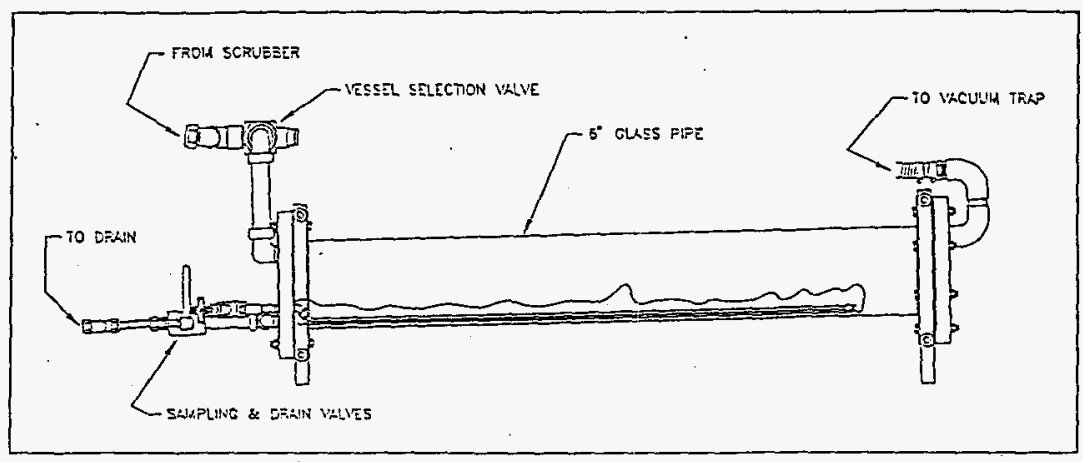

Figure 7 Phase separation vessel

in operation, one separator is filled at a time. The process vacuum is applied at the far end of the separator, causing the gases to travel the length of the vessel. Excess moisture settles out as the gases flow the 4 foot length of the separator. The gas leaving the separator is largely devoid of entrained liquid as it leaves the glovebox and enters the process vacuum system.

When full, the active separator is valved out and the stand by separator is valved in. A liquid sample from the filled tank is taken to check for

5) Pyrex is a trodemerk of Gerning class Herks, Corning, hi 
WHC-SD-CP-FDC-003, Rev 0

Page $B-35$ of $B-47$
ReP. KHC-SD-CP-TA-OOS

Revision 0

Page 33 of 45

nuclear materials and caustic concentration. Once the liquid in the separator is verified to meet release criteria, it is released to the waste drains.

If the separators are allowed to be overfilled, liquid would be pulled into the vacuum trap interrupting flow from the calciner. There is also the possibility that the glass used in the prototype separation unit might be cracked. Should this occur, any leakage would be contained by the glovebox, although vacuum would be lost for the calciner.

\subsection{Phase Separator Test Experience}

The phase separators have performed well in testing, meeting all of their design objectives. One of the separators did crack at a glass seam weld during testing. The crack was caused by the caustic liquid attacking small flaws in the glass weld.

\subsection{Phase Separator Design Enhancements}

Stainless steel will be used for the phase separators in the production calciner system. Level detection instrumentation will be provided to provide level indication and to prevent overflow. 


\subsection{VACUUM TRAP}

The vacuum trap was fabricated from stainless steel plate, angle iron, perforated plate, fittings, bolts, a polyethylene float, and a 6 inch long piece of 3 inch diameter pyrex ${ }^{\mathrm{s}}$ pipe. In the event liquid enters the vacuum trap, the float will plug the flow and interrupt the vacuum. This interruption in flow from the calciner would cause the pressure release cap to lift, safely venting calciner offgases into the glovebox.

Liquid in the vacuum trap will drain back to the phase separator as soon as an empty unit has been valved in. For vacuun to be restored to the calciner, the 26 inch vacuun service to the glovebox will have to be interrupted briefly by closing the vacuum line valve to allow the float to be released.

\subsection{Potential Vacuum Trap Failure Mechanisms}

No credible faiture modes are evident for this piece of equipment.

\subsection{Production Version Vacuum Trap Design Enhancements}

Level detection instrumentation in the production calciner collection vessels will prevent licuid overflow from the phase separators. The production version vacuum trap will also be fitted with an alarm, and interlocked with the feed pumps as a backup.

6) Pyrex is a tradentitk of corning Glass Works, corning, ky 


\subsection{VACUUM REGULATOR}

The vacuum regulator controls the level of vacuum inside the calciner. The vacuum regulator was modified at the factory to our specifications. The regulator started out as a standard Fisher Y612 model with a stainiess steel body, and was modified with a larger Teflon ${ }^{07}$ protected Nitrile diaphragm and an external control port to allow the unit to control the vacuum in the range needed. The regulator is designed to be mounted in any position. The regulator control port receives its pressure reference sensing from the inside of the calciner through $1 / 4$ inch tubing.

\subsection{Vacuum Regulator Test Experience}

The vacuum regulator has functioned well in testing, and the ability it has provided to adjust the vacuum level as needed has been useful.

The possibility for the vacuum sensing line to become plugged by powder from within the calciner vessel was recognized during early testing on the magnesium oxide stand-in. The burst of air from the filter blow-back dislodged material from the ofigas filters in the vicinity of the vacuum tap and caused some to be dratin into the sensing line.

The problem was resolved by inserting a solenoid valve into the sensing line synchronized with the blow-back pulses. The valve closes during the pressure pulses to prevent dust being forced into the line. Since this modification was incorporated, and there has been no evidence of material entering the sensing line.

Given the reliability of the other similar vacuum regulators in the facility, failure of this unit is unlikely for many years. No difficulties are anticipated with the vacuum regulator over any conceivable life of the calciner system.

\subsection{Recommended Vacuum Regulator Design Enhancements}

The regulator itself is extremely reliable and has no credible failure conditions other then nomal wear and tear due to extended use. No modifications are anticipated.

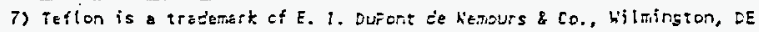


WHC-SD-CP-FDC-003, Rev 0

Page $B-38$ of $B-47$
Ref. KHC-SD-CP-TA-OOg

- Revision 0

Page 36 of 45

\subsection{INSULATION}

The calciner vessel and offgas tubing are thoroughly insulated to ensure efficient operation of the calcination process and to prevent overheating of the glovebox. The calciner top $p l a t e$ and the jacket furnace surrounding the calciner reaction section are insulated with high efficiency castable fibrous insulation. The filter section and the offgas tubing were originally insulated with a ceramic fabric insulation blanket. The insulation performed well, keeping the internal temperature of the glovebox well within its design limits.

Criticality safety considerations led to the design of an alternative, nonabsorptive insulation. A reflective multi-iayered stainless steel foil "mirror" insulation jacket was custom fabricated to our specifications.

Thermal analysis determined that it will be nearly as efficient as the fibrous insulation blanket. The analysis found that the worst-case surface temperature of the insulation jacket will be under $50^{\circ} \mathrm{C}$, well within our safety margin.

The mirror insulation jacket was immersion tested and verified to not retain liquid. It also provides easier access for maintenance on the calciner than the blanket. The thermal efficiency of the mirror insulation has not yet been in-service tested, but it is anticipated that it will perform vell in operation. 
WHC-SD-CP-FDC-003, Rev 0

Page B-39 of B-47
Ref. HHC-SD-CP-TA-009

Revision 0

Page 37 of 45

\subsection{INTERLOCKS AND CONTROLS}

All of the functions of the calciner and its various system components are locally controlled, either from the dedicated calciner control panel, or from within the calciner glovebox. There are six primary variables involved in the calciner control process; these are temperature, feed flow rate, caustic makeup flow, agitator speed, vacuum level, and air flow. The filter blow-back pulse volume and duration also impact calciner operation: Each of these variables can be safely interrupted from the master stop switch located on the control panel.

\subsection{Calciner Temperature Controls}

The calciner is provided with two high temperature electric furnaces, each with its own power supply. The calciner vessel jacket is heated from a 6000 Watt, 240 Voit, 55 Amp vertical tube furnace. This furnace is fitted with molybdenum disilicide elements capable of continuous operation at up to $1600^{\circ} \mathrm{C}$. The internal doise is heated by an 1100 Watt, 12 Volt, 90 Amp unit capable of operation at up to $1400^{\circ} \mathrm{C}$.

The furnaces are supplied from high powered phase-angle controlled SCR current sources. The pover supplies are operated from a programmable temperature controller. The temperature controller nonitors the temperature on the outside of the calciner at a point near the center of the jacket heating elements. At full temperature, the heating elements are designed to operate about $250^{\circ} \mathrm{C}$ above the temperature of the vessel wall; this is the temperature drop across the air space between the furnace and the vessel.

The controller varies the amount of current the power sources supply to the furnaces to maintain a set ramp-up rate, typically between $5^{\circ}$ and $10^{\circ} \mathrm{C}$ per minute. Any faster then $10^{\circ} \mathrm{C}$ per mirute vould cause excessive thermal stress on the calciner due to uneven expansion of its various components. Huch slower then $5^{\circ}$ per minute would take unnecessarily long to reach operating temperature of $1000^{\circ} \mathrm{C}$. It typically takes about 2 hours for the calciner to reach operating temperature. 
WHC-SD-CP-FDC-003, Rev 0

Page $B-40$ of $B-47$
Ref.WHC-SD-CP-TA-0O9

Revision 0

Page 38 of 45

Once at full operating temperature, the controller modulates the polier to maintain its setpoint temperature. For example, as the feed solution or the injection air flow rate is increased, the controller senses the temperature begin to drop from the increased load and increases power to the furnaces unti] the temperature stabilizes. It then throttles back the output power to maintain the setpoint temperature.

The controller also provides a programmable interlock to the material feed pump. This interlock prevents the feed pump from operating whenever the calciner vessel temperature is below $700^{\circ}$. This prevents inadvertent flooding of the calciner with liquid feed, and prevents paste formation in the material bed due to quantities of liquid introduced into the powder bed at low temperatures.

The temperature control system is designed to fail safely. A thermocouple failure will be detected automatically, causing shutdown of the furnace power supply. However, dislocation of the temperature controller thermocouple probe would not be automatically detected and could result in thermal runaway of the furnaces. Vessel temperatures above $1250^{\circ} \mathrm{C}$ could cause destruction of the calciner. To preciude this, a calciner overtemperature interlock has been provided. This interlock is provided by a programable temperature alarm relay which receives input from a redundant thermocouple probe. This probe senses temperature on the calciner vessel wall closest to the heating element. should the vessel temperature rise above the alarm setpoint $\left(1100^{\circ} \mathrm{C}\right)$, it will automatically shut off power to the furnaces and provide a local overtemperature alarm.

A total of 20 thermocouples, including the two primary probes, were incorporated into all areas of the prototype calciner. These permitted an accurate temperature profile to be produced, and enabled us to rule out any potential trouble spots due to temperature extremes. Many of these thermocouples will be eliminated from the production model vertical calciner.

One of the two primary thermocouple probes became bent during maintenance. When it was inserted into the furnace, it didn't track well through its port. It made contact between the heating element and the calciner vessel, short circuiting and burning out the heating element. The thermocou- 
WHC-SD-CP-FDC-003, Rev 0

Page B-4l of B-47
Ref. KHC-SD-CP-TA-009

Revision 0

Page 39 of 45

ple guide holes through the furnace insulation were since reinforced with ceramic guide tubes, and the thermocouple probes themselves have been encased in ceramic insulation over their entire length. This will prevent any similar occurrence.

The fragility of the jacket furnace insulation and heating elements was established in early testing of the calciner. The furnace was damaged twice in handling prior to installation and testing. The furnace was repaired at the factory and returned to service. A cage was fabricated around the terminals to prevent contact and damage to the elements. The cage also protects personnel from potential contact with live electrical components. The production calciner furnace will also be provided with a ceramic terminal bushing to demage to the elements from handling.

It was found in testing that the jacket furnace did not provide sufficient power to drive the process at the full design flow rate. When investigated, it was found that the furnace supplied by the vendor was a lower power off-the-shelf unit rather than custom high-power furnace specified. The vendor error was corrected by the menufacturer at their expense. The jacket furnace power supply was upgraded while we were waiting for the replacemient furnace. Available poler is now more than adequate to run the process at the full design flow rate.

\subsection{Feed Solution and Caustic Makeup Flow Controls}

The material and caustic make up feed pumps are two identical corrosion resistant, lab scale metering pumps. The pumps are adjustable over a range between 0 and 15 liters per hour.

Both fumps are interlocked with the master stop switch. The material feed pump is also interlocked with iurnace temperature controller and the process air supply systein.

The feed pump is enabled by the temperature controller to operate only above $700^{\circ} \mathrm{C}$, as described in section 11.1. It is also linked to a low air pressure shut down switch. This switch is designed to shut the pump down whenever the feed air pressure falls bejow 60 psi (see Section 5.4.2). 
WHC-SD-CP-FDC-003, Rev 0

Page $B-42$ of $8-47$
Ref. WHC-SD-CP-TA-DO9

Revision 0

Page 40 of 45

\subsection{Agitator Drive and Controls}

The agitator is powered by a torque-1 imited $1 / 4$ horsepower, variable speed dc motor. The speed is controllable between zero and $120 \mathrm{rpm}$. It is disabled by the master stop button. The agitator drive has functioned well in testing. It successfully shut down both times the shaft bound in its collar, preventing potential damage to the test equipment. The production calciner will be provided with an agitator tachometer and low speed alarm.

The drive motor transfers powers to the agitator over a chain and sprocket assembly with a one-to-one gear ratio. The drive gear is linked to the agitator shaft with a slide coupling to allow quick disconnection for ease of maintenance. The assembly is enclosed in a guard housing to prevent any pinch points.

The chain drive prevents heat from being conducted from the aitator shaft to the motor. This arrangement also serves to move the motor away from the area of high convective heat flow from the calciner.

\subsection{Glovebox High Temperature Interlock}

A programable glovebox overtemperature alarm relay provides a continuous readout of the glovebox internal temperature near the ceiling adjacent to the exhaust inlet. The relay is set to shut down power to the calciner furnaces if the internal glovebox temperature exceeds $50^{\circ} \mathrm{C}$. This interlock functioned properly in testing using a direct heat source. The glovebox temperature has not exceeded the relay trip point under test conditions. 
WHC-SD-CP-FDC-003, Rev 0

Page $B-43$ of $B-47$
Ref, WHC-SD-CP-TA-OOO

Revision 0

Page 41 of 45

\subsection{CONCLUSIONS}

Due to the sensitivity of this project, a conservative engineering design philosophy was followed throughout the development process. An attempt was made to perfect the caiciner prototype on paper as much as possible. All aspects of the design were thoroughly researched, analyzed, and in many cases tested prior to preparing the fabrication sketches.

A conscious decision was made to develop a production-scale prototype that simulated the production unit to the greatest extent possible. Documentation of the prototype was managed to the same rigorous standards as a final design. The result is that core desigri documentation can be directly used for fabrication of the production-scale calciner.

Development testing of the calciner was quite successful and fully established the sounoness of the design. No major design challenges were encountered during the course of the development testing process. Corrective modifications were identified and incorporated as necessary with each test run. of the prototype calciner. Its performance and reliability have continued to improved with each test run. there is littie mechanical data left to be gained from further operational testing.

To prepare the calciner for continued process chemistry testing, the main calciner furnace and its power supply were replaced, and the fiber insulation bianket was replaced with the "mirroi" insulation jacket. These changes will allow criticality safety limits to be modified and enable a full range of material types and feed densities to be evaluated under continued process chemistry testing. The efficacy of these changes will be evaluated in a follow-on report.

The remaining mechanical modifications necessary to prepare the calciner design for production use will be to enhance process controls for the nuclear process operators and to facilitate maintenance in certain key areas. No challenges were encountered during the testing process that will preclude the production scale from reliably processing the available stock of plutonium nitrate solutions at the PFP. Testing should continue to obtain additional information related to process chemistry. 
APPENDIX A SUMMARY OF CALCINER TEST EXPERIENCE

\begin{tabular}{|c|c|c|c|}
\hline Test performed & Hours & 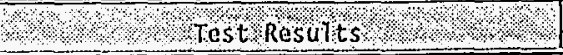 & 2.8 Actions Taken $\%$ \\
\hline Weld Integrity & 4 & $\begin{array}{l}\text { visual and dye penetration tests ok } \\
\text { some slight weld undercutting evident. }\end{array}$ & - \\
\hline Corrosion Resistance & 14 & $\begin{array}{l}\text { Adequate corrosion resistance to ni- } \\
\text { tric vapors. Significant corrosion } \\
\text { of } 310 \text { SS in concentrated boiling } \\
\text { acid at Tiquid/vapor boundary. }\end{array}$ & \\
\hline Scrubber Testing & 80 & $\begin{array}{l}\text { excellent cooling and mixing effects } \\
\text { in test: scrubber }\end{array}$ & \\
\hline High Temp Oxidation & 96 & $\begin{array}{l}\text { all alloys tested with exception of } \\
\text { platinum lose mass over extended } \\
1000^{\circ} \mathrm{C} \text { cycling in Sludge Stabiliza- } \\
\text { tion Furnaces. Besides platinum, } \\
\text { Hastelloy and } 310 \text { stainless are best. }\end{array}$ & 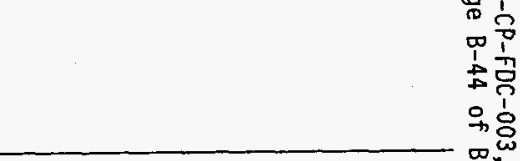 \\
\hline System Shakedown \#1 & 4 & $\begin{array}{l}\text { scrubber action exceilent, } \\
\text { agitator wouldn't run, } \\
\text { no air pressure }\end{array}$ & $\begin{array}{l}\text { replaced drive fuse, } \\
\text { fixed valve }\end{array}$ \\
\hline System Shakedown $\mathbb{Z} 2$ & 4 & $\begin{array}{l}\text { agitator speed calibrated, } \\
\text { alignment bearing squeaked }\end{array}$ & $\begin{array}{l}\text { shaft coupling adjusted, graphite } \\
\text { lubricant to bearing }\end{array}$ \\
\hline System Shakedown $\| 3$ & 8 & $\begin{array}{l}\text { instrumentation nonfunctional, } \\
\text { furnace power supplies inoperative, } \\
\text { product receiver clamp difficultics }\end{array}$ & $\begin{array}{l}\text { programmed instrumentation, } \\
\text { corrected miswiring, } \\
\text { modified receiver ciamp }\end{array}$ \\
\hline Controls and interlocks & 6 & $\begin{array}{l}\text { alt controls and interlocks } \\
\text { functioned correctiy, } \\
\text { Did not: verify filter DPI }\end{array}$ & $\begin{array}{l}\text { added caustic feed pump and } \\
\text { temperature controller to master } \\
\text { shut down interlock }\end{array}$ \\
\hline $\begin{array}{l}\text { High Temp } / 1 \\
\text { (Dry) }\end{array}$ & 4 & $\begin{array}{l}\text { inadequate power to furnace, } \\
\text { inadequate air flow through calciner, } \\
\text { thermal lag between furnace and } \\
\text { control thermocoupie }\end{array}$ & $\begin{array}{l}\text { reconfigured controller wiring, } \\
\text { increased vacuum level }\end{array}$ \\
\hline
\end{tabular}




\begin{tabular}{|c|c|c|c|}
\hline ४ैTest performed & Hours & \% 1 Test Results $\%$ ( & $1 \%$ Actions Taken 1 \\
\hline \multirow[t]{2}{*}{$\begin{array}{l}\text { High Tenp } \| 2 \\
\text { (Dry) }\end{array}$} & 17 & $\begin{array}{l}\text { reached } 800^{\circ} \mathrm{C} \text { set point temperature, } \\
\text { blowback timing problem, } \\
\text { control thermocouple temp. Tag, } \\
\text { fractured upper bearing, } \\
\text { chipped lower bearing, } \\
\text { meled themocouple connector }\end{array}$ & $\begin{array}{l}\text { calibrated blowback controls, } \\
\text { replaced tiglit bearings, } \\
\text { relocated thermocouple connector }\end{array}$ \\
\hline & & $\begin{array}{l}\text { broke furnace clement during } \\
\text { maintenance }\end{array}$ & $\begin{array}{l}\text { replaced furnace, fabricated ter- } \\
\text { minal guard }\end{array}$ \\
\hline $\begin{array}{l}\text { High Tcmp } \# 3 \\
(\text { Dry) }\end{array}$ & 23 & $\begin{array}{l}\text { reached } 1000^{\circ} \mathrm{C} \text { sctpoint temperature, } \\
\text { control thermocouple temp. Iag } \\
\text { overshot setpoint temp., } \\
\text { high filter dp, } \\
\text { carbide flake scored agitator shaft, } \\
\text { filter power seems inadequate }\end{array}$ & replaced carbide bushing \\
\hline $\begin{array}{l}\text { Low Temp Agitator Run, } \\
\text { Mg0 bed }\end{array}$ & 4 & bcaring still squeaking & applied graphite spray \\
\hline $\begin{array}{l}\text { High Temp \#4 } \\
\text { (magnesium nitrate feed) }\end{array}$ & $\begin{array}{l}23 \\
(0.2)\end{array}$ & $\begin{array}{l}\text { excecded } 1000^{\circ} \mathrm{C} \text { setpoint tcmperature, } \\
\text { furnace fuse failed, } \\
\text { control thermocouple temp. lag, } \\
\text { high filter dp, } \\
\text { bearing heavily scored shaft } \\
\text { agitator not mixing adequately } \\
\text { excecded design feed rate } x 3 \\
\text { vented stcam and powder }\end{array}$ & $\begin{array}{l}\left(1040^{\circ} \mathrm{C}\right) \\
\text { installed higher powered supply } \\
\text { moved control thermocouple from } \\
\text { base to jacket } \\
\text { adjusted blowback and air flow, } \\
\text { carbide bearing replaced with } \\
\text { graphite } \\
\text { twisted paddles } \\
\text { calibrated feed pump } \\
\text { installed shaft scal, vacuum tap } \\
\text { cut-off solenoid valve, replaced } \\
\text { bed with } \mathrm{CeO}_{2}\end{array}$ \\
\hline $\begin{array}{l}\text { High Temp } 14 \\
\text { (cerous nitrate feed) }\end{array}$ & $\begin{array}{l}23 \\
(3)\end{array}$ & $\begin{array}{l}\text { temp. stable at setpoint of } 1000^{\circ} \mathrm{C} \text {. } \\
\text { graplite shaft bearing held up weit } \\
\text { made good product powder } \\
\text { ngitator secned under-powered }\end{array}$ & replaced $1 / 12 \mathrm{hp}$ drive with $1 / 4 \mathrm{hp}$ \\
\hline
\end{tabular}




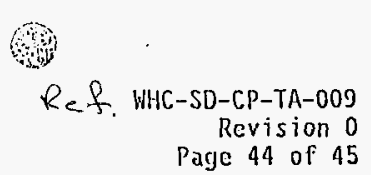

\begin{tabular}{|c|c|c|c|}
\hline test perforthed & Hoursts & 4,4, Test Results & 1 14 Actjons Taken \\
\hline High Tcmp $\| 5$ & 22 & $\begin{array}{l}\text { temp. to } 800^{\circ} \text { when aborted test } \\
\text { agitator shaft binding: } \\
\text { seal follower galled and froze shaft }\end{array}$ & $\begin{array}{l}\text { replaced stainless follower with } \\
\text { graphite }\end{array}$ \\
\hline $\begin{array}{l}\text { High Tenp } \# G \\
\text { (ccrous nitrate feed) }\end{array}$ & $\begin{array}{c}25 \\
(2.5)\end{array}$ & $\begin{array}{l}\text { dome heater power stuck on full } \\
\text { temp. stable at setpoint of } 1000^{\circ} \mathrm{C} \\
\text { fecd ratc of } 4 \text { liters/lar sustained, } \\
\text { good quality powder produced } \\
\text { (LoI }=0.571 \text { ) } \\
\text { light caking on filters and internal } \\
\text { surfaces } \\
\text { still not enough furnace power }\end{array}$ & fixed stuck 'load test' button \\
\hline $\begin{array}{l}\text { High Temp } \| 7 \\
\text { (ccrous nitrate feed) }\end{array}$ & $\begin{array}{c}25.5 \\
(2)\end{array}$ & $\begin{array}{l}\text { temp. stable at setpoint of } 1000^{\circ} \mathrm{C} \\
\text { dust on dome heater } \\
\text { jacket heater output only } 1000 \mathrm{w} \\
\text { (1/6 rated output:) }\end{array}$ & $\begin{array}{l}\text { seal weld added to overflow port to } \\
\text { ordered replacement furnace whic on } \\
\text { meets original specifications }\end{array}$ \\
\hline Held inspection & 4 & pressure test, visual inspection OK & all welds in good condition \\
\hline $\begin{array}{l}\text { High Temp } 1 / 8 \\
\text { (corous nitrate feed) }\end{array}$ & $\begin{array}{c}25.5 \\
(4)\end{array}$ & tcmp. stable at setpoint of $1000^{\circ} \mathrm{C}$ & \\
\hline $\begin{array}{l}\text { System retest } \\
\text { Calciner in "hot" } \\
\text { glovebox }\end{array}$ & 22 & water in air line & $\begin{array}{l}\text { installed self draining line traps } \\
\text { added low air pressure interlock }\end{array}$ \\
\hline $\begin{array}{l}\text { High Temp } \$ 9 \\
\text { (plutonium nitrate feed) }\end{array}$ & $\begin{array}{c}23.5 \\
(3)\end{array}$ & $\begin{array}{l}\text { temp. dropped from setpoint of } 1000^{\circ} \mathrm{C} \\
\text { to } 850^{\circ} \mathrm{C} \text { with feed } \\
\text { agitator stalled }\end{array}$ & Larger power supply ordered \\
\hline $\begin{array}{l}\text { High Tcmp flo } \\
\text { (plutonitum nitrate fecd) }\end{array}$ & 22 & $\begin{array}{l}\text { tcmp. stable at setpoint of } 1000^{\circ} \mathrm{C} \\
\text { fecd tube blocked }\end{array}$ & $\begin{array}{l}\text { Replaced tube, added step to } \\
\text { procedure to plug tube after } \\
\text { operation }\end{array}$ \\
\hline $\begin{array}{l}\text { High Temp \#II } \\
\text { (pTutoniun nitrate fecd) }\end{array}$ & $\begin{array}{c}25 \\
(3.4)\end{array}$ & $\begin{array}{l}\text { temp. dropped from setpoint of } 1000^{\circ} \mathrm{C} \\
\text { to } 850^{\circ} \mathrm{C} \text { with feed } \\
250 \text { grans feed with no product output }\end{array}$ & \\
\hline
\end{tabular}




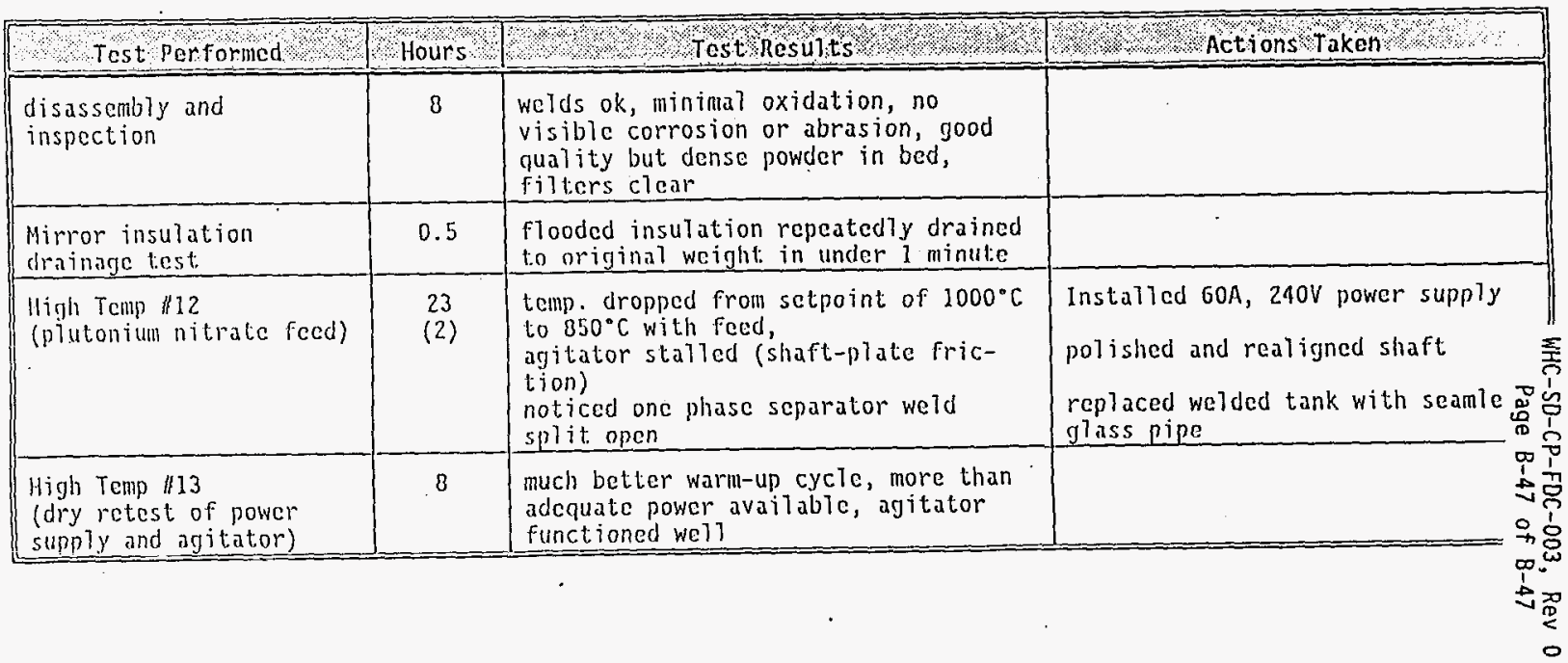




\section{DISTRIBUTION SHEET}

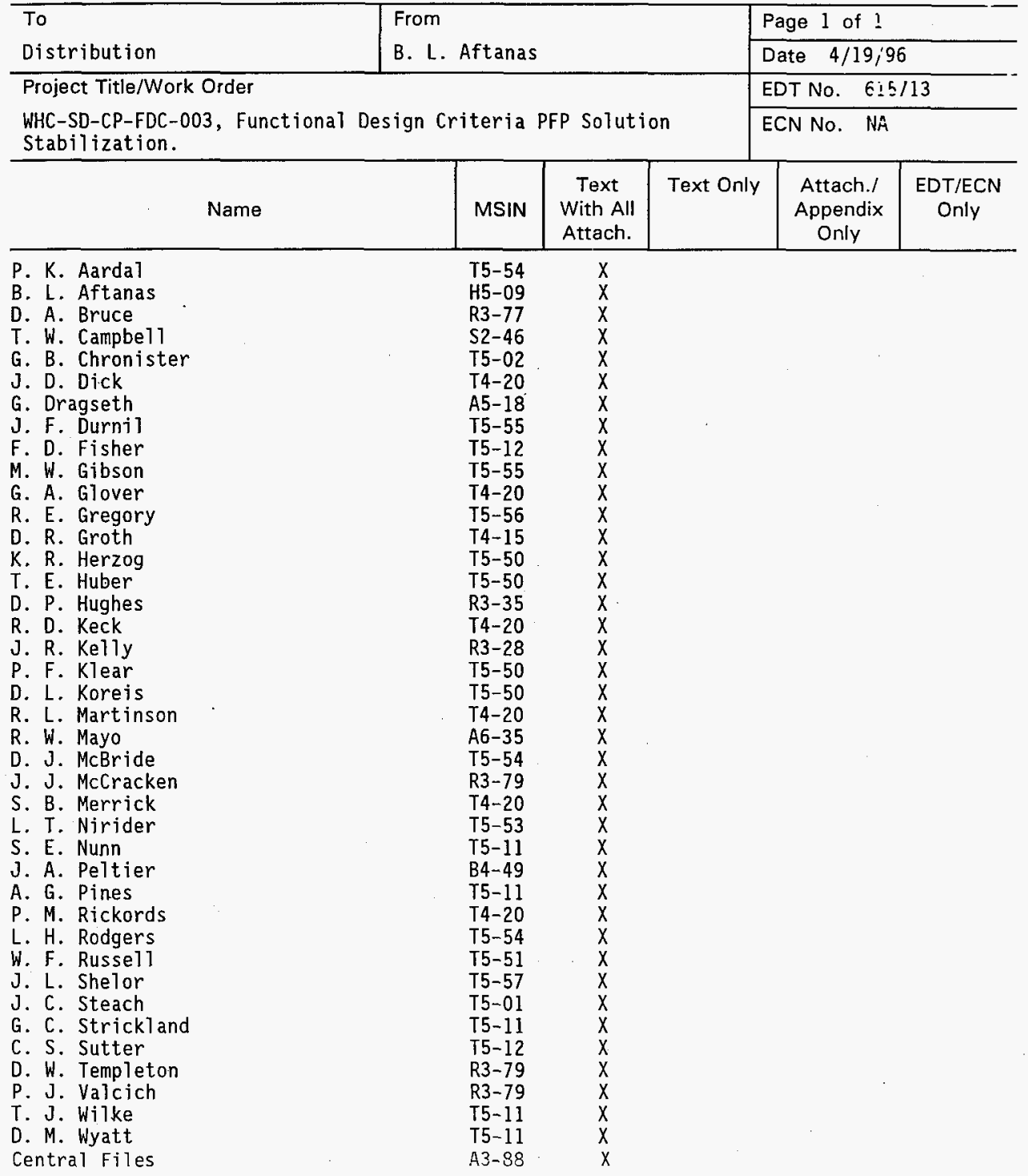

